\title{
NUREMBERG REVISITED IN BURMA? AN ASSESSMENT OF THE POTENTIAL LIABILITY OF TRANSNATIONAL CORPORATIONS AND THEIR OFFICIALS IN BURMA UNDER INTERNATIONAL CRIMINAL LAW
}

By

\section{Mary Ann Johnson Navis}

\author{
A dissertation \\ submitted to the Victoria University of Wellington \\ in partial fulfilment of the requirements for the degree of \\ Master of Laws
}

Victoria University of Wellington

2010 


\section{ABSTRACT}

This dissertation focuses on the role played by officials of transnational corporations and transnational corporations themselves in the situation in Burma. The main aim of this dissertation is to assess the liability of officials of transnational corporations in Burma and transnational corporations in Burma for crimes against humanity such as slave labour and for war crimes such as plunder under International Criminal Law. However at present transnational corporations cannot be prosecuted under International Criminal Law as the International Criminal Court only has jurisdiction to try natural persons and not legal persons. In doing this analysis the theory of complicity, actus reus of aiding and abetting and the mens rea of aiding and abetting in relation to officials of transnational corporations will be explored and analysed to assess the liability of these officials in Burma. In doing this analysis the jurisprudence of inter alia the Nuremberg cases, the cases decided by the International Criminal Tribunal for the Former Yugoslavia (ICTY) and the International Criminal Tribunal for Rwanda (ICTR) will be used. This dissertation also examines the problems associated with suing or prosecuting transnational corporations due to the legal personality of transnational corporations and the structure of transnational corporations. At the end

of the dissertation some recommendations are made so as to enable transnational corporations to be more transparent and accountable under the law.

\section{STATEMENT OF WORD LENGTH}

The text of this paper (excluding abstract, table of contents, bibliography and footnotes comprises approximately 39,418 words ) 


\section{ACKNOWLEDGEMENTS}

My heartfelt gratitude to Kevin Riordan for his insights, commitment, guidance, encouragement and support which assisted me greatly to complete this dissertation. My thanks to Professor Richard Boast for his encouragement and support . Finally I would like to extend my thanks and gratitude to my family and friends for their encouragement and most of all to God who made all things possible. 


\section{TABLE OF CONTENTS}

$\begin{array}{lr}\text { ABSTRACT } & 2\end{array}$

ACKNOWLEDGEMENTS 3

I INTRODUCTION 9

II BRIEF HISTORY OF BURMA AND THE CURRENT SITUATION IN BURMA $\quad 12$

A The Junta and Transnational Corporations 12

B The Condition of the People in Burma 13

C Effect of TNC's Activities on the People Of Burma 14

III THE CONTINUING LEGACY OF INDUSTRIALISTS AND TNCS 15

A Industrialists at Nuremberg, TNCs and International Criminal Law15

$\begin{array}{lll}\text { B The Industrialists Cases at Nuremberg } & 17\end{array}$

$\begin{array}{lll}\text { C The Indictments of the Industrialists at Nuremberg } & 17\end{array}$

$\begin{array}{ll}\text { D The IG Farben Trial } & 17\end{array}$

$1 \quad$ Facts of the case 18

$2 \quad$ The indictments 19

$3 \quad$ The judgment of the tribunal under count two (plunder) 19

$4 \quad$ The judgment of the tribunal under count three (slave labour) 26

$5 \quad$ The significance and implication of the IG Farben decision 29

$\begin{array}{lll}E & \text { The Krupp Trial } & 30\end{array}$

1 The indictments 30

2 The offences committed by the Krupp firm under count two (plunder) 30

3The judgment of the Tribunal under count two 32

4 The offences committed by the Krupp firm under count three (slave labour)33 
6 The significance and implication of the Krupp decision 35

F The Flick Trial

1 The judgment of the tribunal under count one (slave labour) 37

2 The judgment of the tribunal under count two (plunder) 38

3 The significance and implication of the Flick decision 39

G The Third Reich in Germany and the Junta in Burma, the Differences 40

H The Legal Principles Derived from the Industrialists Trials at Nuremberg 44

I Lessons from Nuremberg and the Situation in Burma 45

J The Industrialists Cases at Nuremberg and the Officials of TNCs in Burma 46

$\begin{array}{lr}\text { K Conclusion } & 48\end{array}$

IV AN ASSESSMENT OF THE POTENTIAL LIABILITY OF THE OFFICIALS OF TNCS IN BURMA FOR THE CRIME AGAINST HUMANITY OF SLAVE LABOUR UNDER INTERNATIONAL CRIMINAL LAW (ICL)

A The Development of the Crime of Enslavement 49

B The Crime of Enslavement under International Criminal Law 50

C Is the Crime of Enslavement Committed in Burma?

D Is the Crime against Humanity of Enslavement being Committed in Burma?

E The TNCs in Burma and the Yadana Project 58

F The Role Played by TNCs and Officials of TNCs in the Crime Against Humanity of Enslavement in Burma 58

G Complicity; A Growing Phenomenon in International Criminal Law 60

H Some Definitions of Complicity 61

$1 \quad$ Direct corporate complicity $\quad 61$

2 Indirect corporate complicity 62 
3 Silent complicity

4 The three elements of complicity in international crimes

$J$ An analysis of Complicity in the Nuremberg Cases in Relation to the Crime of Enslavement

K An Analysis of the Complicity of the Officials of TNCs in Burma for the Crime of Enslavement

L Aiding and Abetting; a Form of Complicity under ICL

M An analysis of the Actus reus and Mens rea Requirement of Aiding and Abetting in Relation to Industrialists Cases at Nuremberg 69

$N$ The Actus reus and Mens rea Requirement of Aiding and Abetting under ICL

O Have the Officials of TNCs in Burma Satisfied the Actus reus and Mens rea Requirement of Aiding and Abetting the Crime of Enslavement under ICL in Burma?

P Conclusion

V AN ASSESSMENT OF THE POTENTIAL LIABILITY OF OFFICIALS OF TNCS IN BURMA FOR THE WAR CRIME OF PLUNDER UNDER INTERNATIONAL CRIMINAL LAW

A The Development of the Law in Relation to the War Crime of Plunder 78

B The Contemporary Law of Plunder

C The War Crime of Plunder

D The Armed Conflict in Burma

E The Crime of Plunder in Burma?

F Elements of the War Crime of Pillage under Article 8 (2) (e) (v) of the International Criminal Court 
I The Role Played by the Officials of TNCs in the War Crime of Plunder in Burma

J An Analysis of the Complicity of the Industrialists in Relation to the War Crime of Plunder

K An Analysis of the Complicity of the Officials of TNCs in Burma in Relation to the War Crime of Plunder

L An Analysis of the Actus Reus and Mens Rea requirement of Aiding and Abetting of the Industrialists in Nuremberg in Relation to the War Crime of Plunder

M Has the Officials of TNCs in Burma Satisfied the Actus reus and Mens rea Requirement of Aiding and Abetting the War Crime of Plunder under ICL?

N Conclusion

O The members of the Corporate Board of TNCs that Should be Prosecuted for Being Complicit in the War Crime of Plunder and Crime Against Humanity of Enslavement

VI TRANSNATIONAL CORPORATIONS IN THE $21^{\text {st }}$ CENTURY

A Transnational Corporations in the Global Arena

B Transnational Corporations as Subjects under International Law

C The Regulation of Transnational Corporations

D Can TNCs Be Liable for Human Rights Abuses and International Crimes

E The research by Fafo and the Prosecution of Corporations for International crimes by home States

F The Problems Involved in Suing TNCs

G Legal Personality of TNCs

H Piercing the Corporate Veil

I Extraterritorial Jurisdiction and TNCs 
2 Suing of Transnational Corporations by home states

3 The problems of using extraterritorial jurisdiction on TNCs

J Suing of TNCs by the Host States

K The Alien Tort Claims Act

1 Doe v Unacol

L The Weaknesses of the Alien Tort Claims Act

M Conclusion

VII Conclusion

144

BIBLIOGRAPHY

148 


\section{INTRODUCTION}

Transnational Corporations (TNCs) have become power centred entities in the world today where the economic strengths and the power of some TNCs outweigh that of many states. ${ }^{1}$ TNCs play a particularly vital role in developing countries that are rich in natural resources but have weak governance. ${ }^{2}$ Burma is one example of such a country. ${ }^{3}$ The activities of TNCs in Burma have also contributed vastly to various human rights abuses and violations of the laws in the country. ${ }^{4}$ This dissertation assesses the liability of the officials of TNCs and TNCs in Burma under International Criminal Law for International Crimes such as slave labour and plunder which are purportedly being committed in Burma in relation to the Yadana pipeline. ${ }^{5}$ In doing this analysis the jurisprudence of the Nuremberg cases, cases decided under the International Criminal Tribunal for the Former Yugoslavia (ICTY) ${ }^{6}$ will be used. Further cases decided under the International Criminal Tribunal for Rwanda (ICTR) ${ }^{7}$ will also be used.The central thesis of this dissertation is that officials of TNCs in Burma could be liable under International Criminal Law for crimes against humanity such as slave labour and for war crimes such as plunder by being complicit and by aiding and abetting the Burmese Junta in the commission of these crimes.

Chapter II in this dissertation gives a very brief overview of the history of Burma. Further this chapter looks at the incomes generated by the Junta through

${ }^{1}$ See Michael Rolston "Globalizing a Traditional Cottage Industry: International Criminal Organizations in a Global Economy " (2007) 6 Globalization 1,1. Also see Justine Nolan "With power comes Responsibility: Human Rights And Corporate Accountability " (2005) U NSW LJ 38

${ }^{2}$ See Stephen J. Korbin “ Private Political Authority And Public Responsibility: Transnational Politics, Transnational Firms and Human Rights (2008) U Penn 1,3

${ }^{3}$ Report on HRC Resolution 10/27 Human Rights Situation That Requires The Council's Attention (10 March 2010)A/HRC/13/48, para 13, para 102

${ }^{4}$ Report on HRC Resolution 10/27 above n 3, para 111, para 112.

${ }^{5}$ Ibid

${ }^{6}$ For the Statute of the International Criminal Tribunal for the Prosecution of Persons Responsible for Serious Violations of International Humanitarian Law Committed in the Territory of the Former Yugoslavia since 1991 see United Nations (UN): International Law Documentation www.un.org (accessed 30 June 2010)

${ }^{7}$ For the Statute of the International Criminal Tribunal for the Prosecution of Persons Responsible for Genocide and Other Serious Violations of International Humanitarian Law Committed in the Territory of Rwanda and Rwandan citizens Responsible for Genocide and other such Violations Committed in the Territory of Neighbouring States between 1 January and 31 December 1994 see United Nations (UN) : International Law Documentation www.un.org (accessed 30 June 2010) 
its business alliance with the TNCs. Further the effect of the TNCs activities in Burma is looked at and the condition of life experienced by a great majority of the Burmese population is also highlighted.

Chapter III of the dissertation examines in depth the so-called "industrialists cases" decided at Nuremberg; namely the cases of IG Farben, Krupp and Flick and analyses the legal principles that can be deduced from these trials. The legal significance of these cases to modern day officials of TNCs and TNCs is discussed. Certain significant differences between the era of the Third Reich and the Junta in Burma are also discussed in this chapter.

Chapter IV analyses firstly whether the Crime Against Humanity of slave labour is occurring in Burma using the jurisprudence of the ICTY cases. Secondly the role played by the TNCs and officials of TNCs in the commission of the crime of enslavement in Burma is ascertained. Points of law such as complicity and aiding and abetting in the context of International Criminal Law are analysed. First the concept of complicity in International Criminal Law is discussed at length. Then analysis is done to ascertain how complicity was defined in Nuremberg in relation to the crime of enslavement, then the complicity of officials of TNCs in Burma for the crime of slave labour is looked at. Here the actus reus and mens rea requirement of aiding and abetting for the crime of enslavement under the industrialists trials in Nuremberg is explored. Following from this an analysis is done to ascertain as to whether the officials of TNCs in Burma have satisfied the actus reus and mens rea requirement of aiding and abetting the crime of enslavement under International Criminal law.

Chapter V deals with the war crime of plunder. This chapter briefly traces the development in relation to the war crime of plunder and it looks at the state of contemporary law. Subsequently the issue of whether there is a non international armed conflict in Burma is discussed and analysed. In dealing with this issue the jurisprudence of the ICTY cases is relied on. The subsequent issue that is analysed is whether the war crime of plunder is occurring in Burma, in ascertaining this issue again the jurisprudence of the ICTY cases and the International Court of Justice (ICJ) case of DRC v Uganda is discussed. Subsequently first the issue of 
the role of TNCs in the war crime of plunder is explored. Secondly analysis is done to ascertain how complicity was defined in Nuremberg in relation to the war crime of plunder, thirdly the complicity of officials of TNCs in Burma for the crime of plunder is looked at. Further the actus reus and mens rea requirement of aiding and abetting for the crime of plunder under the industrialists trials in Nuremberg is explored. Following from this an analysis is done to ascertain whether the officials of TNCs in Burma have satisfied the actus reus and mens rea requirement of aiding and abetting the crime of plunder under International Criminal law. Finally an analysis is done to determine which of the officials of the TNCs in Burma in relation to the Yadana pipeline could be guilty of being complicit in the war crime of plunder and in the crime against humanity of slave labour.

Chapter VI analyses various aspects of TNCs. First the growing power of TNCs is looked at. Secondly the theory that TNCs are subjects of international law is discussed and analysed. This chapter also analyses the separate legal personality of TNCs and the corporate structure of TNCs. Further the various problems that arise when TNCs are sued at host states and home states are examined. This chapter also looks at the problems in relation to national jurisdiction and the extraterritorial activities of TNCs.

In Chapter VII certain recommendations are made as to how TNCs could be more effectively be made accountable under the law in the future. 


\section{BRIEF HISTORY OF BURMA AND THE CURRENT SITUATION IN BURMA.}

Based on geographical area Burma is the largest country in Southeast Asia ${ }^{8}$ and has a population of 48.8 million. ${ }^{9}$ Seven major ethnic groups form the people of Burma. These ethnic groups are made of the Chins, Kachins, Karens, Kayahs, Mons, Arakanese (Rakhines) and Shans. ${ }^{10}$ Burmans form the largest racial group and accounts for the $68 \%$ of the population in the country. ${ }^{11}$

Burma gained her independence from the British in $1948 .{ }^{12}$ However at the early years of independence most ethnic minorities took up arms in Burma as the ethnic minorities feared that their rights would not be fulfilled. ${ }^{13}$ A democratic government ruled Burma in the wake of her independence however it lasted for less than two decades after which the military took over Burma. ${ }^{14}$ In March 1962 the military in Burma seized power in a coup. ${ }^{15}$ The justification of the coup was based on three reasons first for the preservation of the Union, second to ensure that Burma enjoyed harmony and order and thirdly to solve Burma's economic problems. ${ }^{16}$ More than forty years later it is clear that the military has failed Burma on all three counts. ${ }^{17}$ Since 1962 until today the military Junta has been ruling Burma. ${ }^{18}$

\section{A The Junta and Transnational Corporations}

The Junta and TNCs have signed joint venture agreements for the extraction of natural resources in Burma as Burma is rich in natural resources such as oil and

\footnotetext{
${ }^{8}$ See Report submitted by State parties under article 18 of the Convention on the Elimination of all forms of Discrimination against women (25 June 1999)CEDAW/c/MMR/1

${ }^{9}$ U.S.Department Of State on Burma www.state.gov/r/pa (accessed 10 July 2010)

${ }^{10}$ Aung San Suu Kyi Freedom from fear and other writings (1se ed, Viking Penguin, USA, 1991) 39

${ }^{11}$ Ibid

${ }^{12}$ Angelene Naw, Aung San and the struggle for Burmese Independence $\left(1^{\text {st }}\right.$ ed, Silkworm Books, Thailand,2001)218

${ }^{13}$ James D. Fearon, David D. Laitin, "Burma Random Narratives" in James D.Fearon and David D.Laitin in Burma Random Narratives (Stanford University) 2007,3

${ }^{14}$ Christina Fink Living Silence Under Military Rule (1ed, Zed Books Ltd, London 2001) 27

${ }^{15}$ Josef Silverstein Burma's struggle for democracy: the army against the people (ANU E Press,2004) 73

${ }_{17}^{16}$ Josef Silverstein above n 15,77

${ }^{17}$ Today there is armed conflict in Burma, the people's needs in Burma are not met even at the most marginal level. See HRC Resolution 10/27, above n 3, para 66, para 98.

${ }^{18}$ See Simon Roughneen"Lifting the mask-Irrawaddy" (1 July 2010) The Irrawaddy
} 
natural gas. ${ }^{19}$ In all of these joint venture projects the State government earns massive revenues as the State owned companies such as Union of Myanmar Economic Holdings (UMEH) and Myanmar Economic Corporation (MEC) have a huge percentage of share holding in the joint venture projects. ${ }^{20}$ Since 2000 the Junta has earned a total of $\$ 4.83$ billion from the Yadana project. ${ }^{21}$ However the Junta has not included $\$ 4.8$ billion of these earnings into the national budget. ${ }^{22}$ In 2009 the Junta's revenue from oil and gas sales was $\$ 3$ billion ${ }^{23}$ however the Junta spends 0.5 percent and $0.9 \%$ of its Gross Domestic Product (GDP) on health and education respectively and $80 \%$ of its income goes to State owned enterprises and the military. ${ }^{24}$

\section{B The Condition of the People of Burma}

Despite the lucrative income the Junta enjoys by doing business with the TNCs yet in some states in Burma especially where the ethnic minorities live such as in Chin state the people are deprived of basic necessities. ${ }^{25} 100,000.00$ people in more than 200 villages in Chin state are in need of food. ${ }^{26}$ Further aid in terms of food is needed by about 5 million people in Burma. ${ }^{27}$ About 1 million people in Burma have been displaced and half of them that are displaced are in Eastern Burma where there is armed conflict. ${ }^{28}$ Armed conflict is still prevalent in Eastern Burma, resulting in villagers fleeing the country to avoid the armed conflict that is occurring between the army of the Junta known as the Tatmadaw, and armed groups such as the Kokang fighters. ${ }^{29}$

\footnotetext{
${ }^{19}$ See Hannah Beech "The race For Burma's Riches-the New Great Game” (30 March 2009) Time New Zealand, 25 Also see Report on HRC Resolution 10/27 above n 3

${ }^{20}$ See Piper Rudnick Gray Cary Threat to the Peace in Burma : A call for the UN Security Council to act in Burma (Report commissioned by The Honorable Vaclav Havel, Former President of the Czech Republic and Bishop Desmond M Tutu Archbishop Emeritus of Cape Town, and prepared for UN Security Council to act in Burma,2005) 10,11 Also see Mattthew Smith

"Focus/Burma:The Hunt For Energy at any cost, the politics of doing business with a brutal regime ( 15 November 2007) Bangkok Post Thailand

${ }^{21}$ Report on HRC resolution above n 10/27, above n 3, Para 102

${ }^{22} \mathrm{Ibid}$

${ }^{23}$ Ibid

${ }^{24}$ Report on HRC Resolution 10/27 above n 3, para 98

${ }^{25}$ Report on HRC Resolution 10/27 above n 3,para 100

${ }^{26}$ Ibid

${ }^{27}$ Report on HRC Resolution 10/27 above n 3, para 101

${ }^{28}$ Report on HRC Resolution 10/27 above $\mathrm{n} 3$, para 61

${ }^{29}$ Report on HRC Resolution 10/27 above $\mathrm{n} 3$, para 66
} 
The companies involved in the extractive industries in Burma have a proximate relationship with the armed forces in Burma and these companies rely on the Myanmar military the Tatmadaw to provide security for their various projects. ${ }^{30}$ Burma executes business deals with the global TNCs especially in the natural resources extractive industry and this has led to various human rights abuses and violations of the law on the people of Burma which includes compulsory land acquisitions, massive relocations, displacements, forced labour and portering. ${ }^{31}$ The people of Burma especially the ethnic minorities are subject to systematic violations of the law and human rights abuses. ${ }^{32}$ In March 2010 the Special Rapporteur to Burma Tomas Ojea Quintana recommended that United Nations set up a commission of inquiry with a mandate to inquire whether war crimes and crimes against humanity are occurring in Burma. He had made the following statement: ${ }^{33}$

Given the gross and systematic nature of human rights violations in Myanmar over a period of many years, and the lack of accountability, there is an indication that those human rights violations are the result of a State policy that involves authorities in the executive, military and judiciary at all levels. According to consistent reports, the possibility exists that some of these human rights violations may entail categories of crimes against humanity or war crimes under the terms of the Rome Statute of the International Criminal Court.

\footnotetext{
${ }^{30}$ See Report on HRC Resolution 10/27 above $\mathrm{n}$ 3,para 112

${ }^{31}$ Report on HRC Resolution 10/27 above n 3, para 111, para 112

${ }^{32}$ Report on HRC Resolution 10/27 above n 3, para 120

${ }^{33}$ Report on HRC Resolution 10/27 above n 3, para 121
} 

AND TNCS

A Industrialists at Nuremberg, Transnational Corporations and International Criminal Law

To date no corporations has been held liable for any offence under International Criminal Law simply because there is no provision under the existing statute of the International Criminal Court (ICC) that makes provision to try legal persons for violations under the law. ${ }^{34}$ The Rome Statute has no such provision as the majority of the member states of the ICC with the exception of France were not in favour of extending the ICC statute to cover legal persons. ${ }^{35}$

The significance of the Nuremberg trials to the activities of modern day TNCs in Burma lies in the fact that the Nuremberg Military Tribunal (NMT) and in particular the US Military Tribunal had indicted certain prominent industrialists who had operated during the Nazi $\operatorname{era}^{36}$ (referred to hereafter as "the industrialist.") The Tribunal imputed responsibility to these corporations in the Nazi era that garnered profit by using slave labour and committing pillage during the Second World War even though they could not attribute criminal liability. ${ }^{37}$ The industrialists had worked together with the Third Reich for the sake of

\footnotetext{
${ }^{34}$ Rome Statute of the International Criminal Court A/CONF.139/9, 17 July 1998, art 25 states that the International Criminal Court only has jurisdiction over natural persons

${ }^{35}$ Bussiness and International Crimes -Fafo www.fafo.no/liabilities (accessed 20 Jun 2010)

${ }^{36}$ Officials from the IG Farben ,Krupp and Flick concern were indicted by the Tribunal for various counts of crime. The officials of IG Farben were indicted under count one for planning, preparation, initiation and waging wars of aggression and invasion of other countries, under count two for plunder and spoliation, under count three for slavery and mass murder, under count four for membership in the SS, and under count five for Common Plan or Conspiracy.Officials of the Kupp and Flick concern were also indicted for various counts of crime which included plunder and spoliation and slave labour.

${ }^{37}$ See United States Of America v Carl Krauch,Herman Schmitz, Georg Von Schnitzler,Fritz Gajewski,Heinrich Hoerlein,August Von Knieriem,Fritz Ter Meer, Christian Schneider, Otto Ambros, Max Brueggemann,Ernst Buergin,Heinrich Buete-Fisch,Paul Haefliger,Max Ilgner,Friedrich Jaehne, Hans Kuehne, Carl Lautenschlaeger, Wilhelm Mann, Heinrich Oster, Karl Wurster,Walter Duerrfeld,Heinrich Gattineau,Erich von Der Heyde,Hans Kugler, officials of Farbenindustrie Aktiengesellschaft (1952) VII , Trials Of War Criminals Before The Nuremberg Military Tribunals, 1172 (The IG Farben case is contained in two volumes, Volume VII deals with the introductions of the IG Farben corporation and Volume VIII deals with the crimes of pillage and slave labour committed by IG Farben)
} 
making profits. ${ }^{38}$ The industrialists during the Nazi era had to face the tribunal for the role they played in being complicit with the Third Reich ${ }^{39}$

The US Military Tribunals which presided over the cases known as the "industrialist cases" 40 made statements to the effect that corporations during the Nazi era had committed various crimes. ${ }^{41}$ However those tribunals were unable to pass judgment on the corporations simply because the law at that time did not cover legal persons. ${ }^{42}$ However, Robert Jackson the Chief Prosecutor at the trial of the Major War Criminals at Nuremberg stated that: ${ }^{43}$

The common sense of mankind demands that law shall not stop with the punishment of petty crimes by little people. It must also reach men who possess themselves of great power and make deliberate and concerted use of it to set in motion evils which leave no home in the world untouched.

Robert Jackson's statement seems directly applicable to TNCs of the Nazi era and of today because TNCs became very powerful entities in the $20^{\text {th }}$ century and even more so in the $21^{\text {st }}$ century. ${ }^{44}$ All these three trials involved multi million dollar businessmen. ${ }^{45}$ The industrialists trials at Nuremberg illustrates that not only military leaders and politicians face criminal responsibility for international crimes, but that industrialists can also be prosecuted under international criminal

\footnotetext{
${ }^{38}$ See Gwynne Skinner “Nuremberg legacy Continues: The Nuremberg Trials' Influence On Human Rights Litigation In US Courts Under The Alien Tort Statute (2008) 71 Albany L Rev 321,323

${ }^{39}$ See Anita Ramasastry “Corporate Complicity From Nuremberg To Rangoon, An examination of forced labour cases And Their Impact On the Liability of Multinational Corporations" (2002) 20 Berkeley Berkeley J.Int'l L 105,106.Also see Alberto Costi "Hybrid Tribunals As A Valid Alternative To International Tribunals For The Prosecution Of International Crimes" (2005) NZLR 1,3

${ }^{40}$ The cases of IG Farben,Krupp and Flick are popularly known as the industrialists cases as these three cases involved the indictment and subsequent trials of powerful businessmen during the Nazi era .

${ }^{41}$ Anita Ramasastry above n 39,106

${ }^{42}$ The Nuremberg Military Tribunals did not pass judgments on the corporations itself but in their judgments the Tribunal had clearly indicated that the corporations were used as instruments to commit war crimes and crimes against humanity.For instance see the statement of the Tribunal in United States Of America v Carl Krauch And Twenty Two Others above n 37,1172

${ }^{43}$ See Opening Statement before the International Military Tribunal www.roberthjackson.org/Man/theman2-7-8-1/ (accessed 9 June 2009)

${ }^{45}$ The directors of IG Farben, Krupp and Flick were highly successful businessmen during the rise of the Nazi party and their respective enterprises enjoyed greater success during the Nazi Era in Germany.
} 
law $^{46}$ and private actors such as industrialists can be imputed with liability for being complicit for committing international crimes with repressive governments such as the Third Reich ${ }^{47}$

\section{B The Industrialists Cases at Nuremberg}

In this chapter the Judgments of the tribunals against the industrialists for the war crime of plunder and for the crime against humanity of slave labour will be analysed. This chapter explores the arguments and decisions in the three cases. This chapter also deals with the significance, implications and the legal principles that can be deduced from the Tribunal's judgments at Nuremberg. Further the differences between the era of the Nazi Germany and the era of the Junta in Burma will be looked at and some of the legal significance of these differences will be discussed.

\section{The Indictments of the Industrialists at Nuremberg}

The directors of IG Farben, Krupp and Flick were indicted for inter alia the war crime of plunder and for crime against humanity of slave labour and these were the common grounds of indictment in all the three cases. ${ }^{48}$ For the purpose of thorough analysis of the law, the judgment of these three cases and the significance and implication of these judgments will be dealt with separately .

\section{The IG Farben Trial}

Interessen-Gemeinschaft Farbenindustrie Aktiengeselischaft (hereinafter referred to as I.G. Farben) was instrumental in helping Hitler form the Nazi state in $1933 .{ }^{49}$ Hitler stayed in power as long as he did due to the financial funding of corporate giants such as I.G. Farben. ${ }^{50}$ Indeed so close was the relationship between this major industrial company and the leaders of the Third Reich that it could fairly be said that "Farben was Hitler and Hitler was Farben",51 Before the

\footnotetext{
${ }^{46}$ See Anita Ramasastry above n 39 98,99

${ }^{47}$ Ibid

${ }^{48}$ Four Farben officials were also indicted for being members of the SS. The SS was declared as a criminal organization by the International Military Tribunal

${ }^{49}$ United States Of America v Carl Krauch And Twenty Two Others Volume VII above n 37, 115,116

${ }^{50}$ United States Of America $v$ Carl Krauch And Twenty Two Others above n 37, 122

${ }^{51}$ Senator Homer T.Bone To Senate Committee on Military Affairs, June 41943
} 
Nazi era IG Farben was already well known in Germany for manufacturing chemical and pharmaceutical products. ${ }^{52}$ Farben was an empire in the world and Farben owned coal mines, power plants, iron and steel units, banks and various commercial enterprises. ${ }^{53}$ In the year 1939 it doubled in size and it had great technological and financial influence and participated in various commercial ventures with around 500 foreign firms. ${ }^{54}$ IG Farben's economic influence extended throughout Europe as it had manufacturing plants and holding companies throughout the continent. "Farben's sales companies, research firms, and other agencies were located in every important commercial and industrial centre in the world." 56 Farben could be said to be a successful transnational corporation in the Nazi era. The directors of leading industries such as Farben saw the opportunity to collaborate with Hitler for their own economic profit and as such became partners with Hitler. ${ }^{57}$

\section{$1 \quad$ Facts of the case}

During World War II the officials of Farben plundered private and public properties in other countries which were under the power of Germany at that time. ${ }^{58}$ The officials of Farben acting through the instrumentality of Farben had acquired titles that were permanent to the properties that were actually confiscated from the owners. ${ }^{59}$ Further Farben through its officials had also proceeded to acquire substantial interests in the properties of the individuals which were not agreed to by the owners of these properties. ${ }^{60}$ Farben had also acquired factories and machineries from the countries that Germany had invaded such as from Poland, Norway and France. ${ }^{61}$ The officials of Farben had also employed the use of slave labour in its factories. ${ }^{62}$

\footnotetext{
${ }^{52}$ Anita Ramasastry above n 39, 106

${ }^{53}$ Anthony C. Sutton Wall Street and the Rise of Hitler (GSG Publishers ,2002) 34

${ }^{54}$ United States Of America v Carl Krauch,And Twenty Two Othersabove n 3716.

55 Ibid

${ }^{56}$ Ibid

${ }^{57}$ Ibid

${ }^{58}$ See United States Of America v Carl Krauch And Twenty Two Others above n 37, 1

${ }^{59}$ United States Of America v Carl Krauch And Twenty Two Others (1952), above n 37, 1140

60 Ibid

${ }^{61}$ See United States Of America $v$ Carl Krauch And Twenty Two Others above n 37,1139,1140

${ }^{62}$ United States Of America v Carl Krauch And Twenty Two Others above n 37,52
} 
The IG Farben Trial was held before a United States Military Tribunal under Control Council Law No.10. ${ }^{63}$ The trial involved the indictment of $23^{64}$ officials from the IG Farben conglomerate who were charged for various counts of crimes. ${ }^{65}$ The 23 IG Farben officials were indicted under count two for plunder and spoliation and under count three for the crime of slave labour. ${ }^{66}$ The statement of offence under count two stated that IG Farben had: ${ }^{67}$

Participated in the plunder of public and private property, exploitation, spoliation and other offences against property in countries and territories that came under the belligerent occupation of Germany in the course of its invasion and aggressive war.

The IG Farben trial was one of the largest trials at Nuremberg ${ }^{68}$ and has secured a place in the legal history of the world because for the first time industrialists were prosecuted for being complicit under International Criminal Law for inter alia war crimes and crimes against humanity. ${ }^{69}$ It was the assertion of the Prosecution under Count two that Farben was used as an instrument by the Defendants to commit war crimes and crimes against humanity ${ }^{70}$ and that Farben was used "to strengthen the German war machine." ${ }^{71}$ The Indictment under count two also stated that "Farben marched with the Wehrmacht and played a major role in Germany's programme for acquisition by conquest.",72

\section{Judgment of the tribunal under count two (Plunder)}

In the IG Farben trial the prosecution had argued that plunder was committed by Farben in the various countries that it had conquered that is in Poland, France, Soviet Union, Yugoslavia, Greece and Norway. ${ }^{73}$ The Prosecution

\footnotetext{
${ }^{63}$ United States Of America v Carl Krauch And Twenty Others above n 37,11

6424 individuals were indicted under the IG Farben case but one of them was taken off the indictment list as he was ill.

${ }^{65}$ United States Of America v Carl Krauch And Twenty Two Others above n 37,2

${ }^{66}$ Ibid

${ }^{67}$ United States Of America v Carl Krauch And Twenty Two Others above n 37,39,40

${ }^{68}$ United States Of America v Carl Krauch And Twenty Two others above n 37, 1

${ }^{69}$ See Robert Shnayerson "Judgment at Nuremberg"1

${ }^{70}$ United States of America v Carl Krauch And Twenty Two Others above n 37,1129

71 Ibid

72 Ibid

${ }^{73}$ See United Nations War Crimes Commission Trials Of War Criminals IG Farben And Krupp (UN War Crimes Commission X, 1949) at 18,19
} 
gave the example of plunder which was engineered by the officials of Farben which concerned the factories in Poland after its invasion by Germany. ${ }^{74}$ During this time one of the officials of Farben named Von Schnitzler wrote a letter to another director of Farben Dr Krueger which effectively informed the Third Reich of the fact that there were in Poland at that time three prominent dyestuff factories ${ }^{75}$ at Boruta, Wola and Winnica. ${ }^{76}$ In relation to these plant facilities Von Schnitzler and Kreuger had by way of another letter informed the Ministry of Economics of the Third Reich that a conference was going to be held on that same day and at the said conference a proposal would be made that Farben would be the Trustee to administer the three plant facilities of Boruta, Wola and Winnica and it will be under the total discretion of Farben to decide on the future of these plant facilities that is whether their operations will continue or be closed down so as to enable their supplies to be utilized. ${ }^{77}$ The Third Reich followed Farben's recommendations and as such the three plant facilities were placed under provisional management where the provision managers for these plants were recommended by Farben. ${ }^{78}$ Subsequent to this in June 1940 instead of entering a 20 years lease with Boruta, Farben was given the liberty to purchase Boruta, the sales contract was signed by Von Schnitzler and Farben went ahead and acquired everything in Boruta which included the land, machineries, tools, fixtures and equipments. ${ }^{79}$ The 1006 shares held by the French in Winnicca were obtained by agreement. ${ }^{80}$ Further evidence tendered in court also showed that due to the recommendation of Farben equipments from the Wola and Winnica plant was also dismantled and taken to Germany. ${ }^{81}$

The Prosecution also argued that the officials of Farben had committed plunder in France ${ }^{82}$ in relation to the Francolor agreement. ${ }^{83}$ The Francolor agreement refers to the agreement that the French were coerced to enter into with

\footnotetext{
${ }^{74}$ Ibid

${ }^{75}$ United Nations War Crimes Commission above n 73,19

${ }^{76}$ Ibid

77 Ibid

${ }^{78}$ United Nations War Crimes Commission above n 73,20

${ }^{79}$ Ibid

${ }^{80}$ Ibid

81 Ibid

${ }^{82}$ United Nations War Crimes Commission above n 73,21

83 Ibid
} 
the officials of IG Farben which resulted in IG Farben having a controlling stake of $51 \%$ in the French Corporation known as Francolor. ${ }^{84}$ When Germany invaded France there were three major dyestuff factories in France at that time and these three firms had cartel agreements with Farben. ${ }^{85}$ To ensure that these firms did not proceed with productions Farben influenced the German occupation authority to do two acts firstly to stop the issuance of licenses and secondly to put a stop to the raw materials that were usually sent to the firms in France. ${ }^{86}$ This act of Farben resulted in the standstill of production in the firms in France. ${ }^{87}$ As such France had no alternative and they had to negotiate with the Third Reich and Farben. ${ }^{88}$ Subsequent to this a conference was held in November 1940 where the representatives from Farben, the French industry and the governments of Germany and France were present. Von Schnitzler, Ter Meer and Kugler who were all officials of Farben attended this meeting representing Farben. ${ }^{89}$ At the conference a memorandum was given by Von Schnitzler to the French representative and Farben demanded for a controlling interest in the dyestuff industry and in pursuit of this objective the officials of Farben arranged other meetings with the French. ${ }^{90}$ It soon became apparent that these negotiations will be settled entirely on the terms put forth by the officials of Farben. ${ }^{91}$ A new corporation known as Francolor was created to take over the assets of the three firms known as Kuhlmann, Saint-Clair and Saint-Denis and Farben demanded for a 51 percent interest in Francolor. ${ }^{92}$ At first the French representatives protested against this request and were backed by the government of France, however the industry in France was performing very badly due to the restrictions of raw material which was engineered by Farben. ${ }^{93}$ Therefore France had no alternative and approved the Francolor agreement which resulted in Farben having a 51

\footnotetext{
${ }^{84}$ United Nations War Crimes Commission above n 73, 22

${ }^{85}$ United Nations War Crimes Commission above n 73,22

${ }^{86}$ Ibid

${ }^{87}$ Ibid

${ }^{88}$ Ibid

${ }^{89}$ Ibid

${ }^{90}$ Ibid

${ }^{91}$ Ibid

${ }^{92}$ Ibid

${ }^{93}$ Ibid
} 
percent interest in the stocks in the company. ${ }^{94}$ The Francolor agreement was executed in November 1941 and Von Schnitzler and Ter Meer signed the Francolor agreement on behalf of Farben. ${ }^{95}$ There was a great deal of proof to show that the officials of Farben had used coercion to obtain the consent of France to sign the Francolor agreement. ${ }^{96}$

Concerning the crime of plunder in relation to the Francolor agreement in France the defendants argued that the economic considerations that were taken into account in relation to the Francolor agreement was sound and that the agreement promoted cooperation between Germany and France in the fields of dyestuff and organic products. ${ }^{97}$ The defendants also argued that the Francolor agreement was the result of 'free negotiations" ${ }^{98}$ between Germany and France and that Germany had obligations under the agreement and when Germany discharged these obligations it resulted in the rehabilitation of the French industries. ${ }^{99}$ The officials of Farben had also argued that the actions of Farben which involved controlling interests in the plants and factories which were situated in the occupied territories of Germany had actually achieved one of the aims of the Hague Regulations that is it had restored the economy in the occupied territories. $^{100}$

The Tribunal however did not accept this defence and stated that the acquisitions which were made by Farben did not restore the economy of the occupied territories but rather it made Farben even more wealthy. ${ }^{101}$ Further the Tribunal held that coercion and compulsion was involved in relation to the Francolor agreement and the agreement was not reached due to free negotiations. ${ }^{102}$ Further the Tribunal stated that many of the properties and titles that the officials of Farben acquired was permanent and not temporary, therefore the officials of Farben were also denied the defence that it had restored the

\footnotetext{
94 Ibid

95 Ibid

96 Ibid

${ }^{97}$ United Nations War Crimes Commission above n 73,51

98 Ibid

${ }^{99}$ Ibid

${ }^{100}$ United Nations War Crimes Commission above n 73,50

101 Ibid

${ }^{102}$ United Nations War Crimes Commission above n 73, 51
} 
economy of the occupied territories as evidence showed that they acquired the properties with the intent of permanently depriving the owners of their properties. ${ }^{103}$ In announcing its decision under count two the tribunal stated:- ${ }^{104}$

With reference to the charges in the present Indictment concerning Farben's activities in Poland, Norway, Alsace-Lorraine, and France, we find that the proof establishes beyond a reasonable doubt that offences against property as defined in Control Council Law No.10 were committed by Farben and that these offences were connected with, and an inextricable part of the German policy for occupied countries as above described.

The Tribunal in finding some of the officials of IG Farben guilty of the war crime of plunder stated that: ${ }^{105}$

The form of the transactions were varied and intricate, and were reflected in corporate agreements well calculated to create the illusion of legality. But the objective of pillage, plunder, and spoliation stands out and there can be no uncertainty as to the actual result.

The Tribunal stated that many of the activities of Farben in Poland, Norway and Alsace Lorraine amounted to plunder and in its judgment gave a wide definition to the term plunder. ${ }^{106}$ The Tribunal held that the officials of Farben were guilty of plunder not only when open looting was committed for instance when machineries were removed from some of the factories in Poland but plunder also occurred when corporate contracts that were executed between the officials of Farben and the officials of companies in the occupied territories contained complex and intricate details that seemed legal ${ }^{107}$ but was "only an illusion of legality" 108 and the US Military Tribunal noted that these were also acts of plunder committed by the officials of Farben. ${ }^{109}$ Further even when officials of Farben had obtained controlling or permanent interest in properties as a

\footnotetext{
${ }^{103}$ United Nations War Crimes Commission above n 73, 50

${ }^{104}$ United States Of America v Carl Krauch And Twenty Two Others above n 37, 1140

${ }^{105}$ United States Of America v Carl Krauch And Twenty Two others above n 37,1140

${ }^{106}$ Ibid

${ }^{107} \mathrm{Ibid}$

${ }^{108}$ Ibid

${ }^{109}$ Ibid
} 
consequence of negotiations with the lawful owners, the US Military Tribunal held that this too was an act of plunder. ${ }^{110}$ Plunder was also committed by the officials of Farben when the Third Reich had conquered certain territories and subsequent to this the officials of Farben proceeded to acquire permanent titles to the properties found in these occupied territories. ${ }^{111}$

The tribunal termed all these acts of the officials of Farben as plunder as it was clear to the Tribunal that firstly the lawful owners never gave their consent freely in the transactions that took place, as there was always some coercion which had forced the lawful owners to enter into agreements and contracts with IG Farben. ${ }^{112}$ Secondly the threat of the military was ever present in all the negotiations that took place. ${ }^{113}$ Thirdly the acquisition by the officials of Farben of the shares, titles and other properties were permanent and not temporary. ${ }^{114}$

The tribunal went on further to state that the action of Farben and the representatives of Farben were identical to the plunder or pillage committed by other persons under the Third Reich such as the soldiers, the public officials and officers. ${ }^{115}$ The Tribunal made a further finding that Farben had taken its own initiative to acquire the properties from its lawful owners and that the military was a threat that was always present during the transactions that happened. ${ }^{116}$ Through the acts of plunder Farben became more wealthy. ${ }^{117}$ The Tribunal asserted that such blatant acts by Farben violated the Hague Regulations. ${ }^{118}$ It was also the contention of the tribunal that although these transactions had the external appearance of being legal and intricate with complex corporate contracts being drawn out but all these were only an "illusion of legality"119 as the fact was that crimes such as spoliation and plunder had been carried out by Farben. ${ }^{120}$ Prior to

\begin{tabular}{l}
\hline${ }^{110} \mathrm{Ibid}$ \\
${ }^{111} \mathrm{Ibid}$ \\
${ }^{112} \mathrm{Ibid}$ \\
${ }^{113} \mathrm{Ibid}$ \\
${ }^{114} \mathrm{Ibid}$ \\
${ }^{115} \mathrm{Ibid}$ \\
${ }^{116} \mathrm{Ibid}$ \\
${ }^{117} \mathrm{Ibid}$ \\
${ }^{118} \mathrm{Ibid}$ \\
${ }^{119} \mathrm{Ibid}$ \\
${ }^{120} \mathrm{Ibid}$
\end{tabular} 
passing judgment the tribunal stated that individuals cannot take refuge under the guise of a corporation to escape liability, the Tribunal stated that: ${ }^{121}$

Conversely, one may not utilize the corporate structure to achieve an immunity from criminal responsibility for illegal acts which he directs, counsels, aids, orders, or abets. But the evidence must establish action of the character we have indicated, with knowledge of the essential elements of the crime."

The Tribunal in passing judgment stated that "Farben as a corporate entity had been directly involved in war crimes and crimes against humanity." 122 At the conclusion of the trial the Tribunal found eight officials of IG Farben guilty under count two for the war crime of plunder, four officials were found guilty for the crime of slave labour and one official was convicted of both counts of crime i.e. plunder and slave labour. ${ }^{123}$ Ten of the officials indicted were acquitted of all chargers. $^{124}$

The tribunal acquitted many of the officials accused of the crime of plunder because the tribunal found that many of them did not engage in conduct that was positive in relation to the plunders that is these officials did not take part in the acts by giving orders, by approving and by authorizing the execution of policies which was criminal. ${ }^{125}$ Where the plunder committed was in transactions which were legal only in form the tribunal found that some of the officials did not possess knowledge that the property was taken against the will of the owner and at the time the military was occupying the territory. ${ }^{126}$ Further those who had no knowledge about how some transactions were occurring were also acquitted. ${ }^{127}$ For instance in the case of Von Knieriem a lawyer in the Farben enterprise was acquitted of this count of crime as the tribunal found that no evidence was established which proved that he had the requisite knowledge about the methods employed by Farben to secure the properties from its lawful owners. ${ }^{128}$ On the other hand officials of Farben such as Ter Meer and Von Schnitzler were guilty

${ }^{121}$ United States Of America v Carl Krauch And Twenty Two Others above n 37,1153

${ }^{122}$ Anita Ramasastry above n 39,107

${ }^{123}$ United States Of America v Carl Krauch And Twenty two Others above n 37,1153-1196

${ }^{124}$ Ibid

${ }^{125}$ See United States Of America v Carl Krauch And Twenty Two Others above n 37,1157

${ }^{126}$ Ibid

${ }^{127}$ Ibid

${ }^{128}$ United States Of America v Carl Krauch And Twenty Two Others above n 37,1159 
under this count as they had knowledge about the way the properties were taken from the lawful owners as they themselves had taken positive actions in such negotiations. $^{129}$

\section{$4 \quad$ Judgment of the tribunal under count three (slave labour)}

Under Count three of the offence, evidence showed that during World War II the Farben plant lacked manpower. ${ }^{130}$ Farben had set up their fourth Buna plant in Auschwitz and the officials of Farben had used concentration camp workers from the Auschwitz camps to work at their Buna plant. ${ }^{131}$ Slave labour was also used by the officials of Farben at the Fuerstengrube coal mine. ${ }^{132}$ Evidence showed that the Buna plant at Auschwitz and the Fuerstengrube coal mine were both private projects handled by Farben. ${ }^{133}$ The officials of Farben had taken their own initiative to obtain and make use of the slave labourers in these two enterprises. ${ }^{134}$ The officials of Farben had also applied to the Reich labour office for slave labour and had procured the slave labourers although they knew the hardships that these slave labourers were going through. ${ }^{135}$

In defence to the crime of slave labour the defendants had argued the defence of necessity. ${ }^{136}$ The defendants' argument was that the Third Reich had given them quotas in relation to production which had to be met. ${ }^{137}$ The officials of Farben asserted that they were under a great deal of coercion to use the slave labours and hence they lacked intent which was a necessary ingredient to establish the criminal offence. ${ }^{138}$ As regards this issue the Tribunal inquired what

\footnotetext{
${ }^{129}$ United States Of America v Carl Krauch And Twenty Two Others above n 37,1156,1159-1160

${ }^{130}$ United Nations War Crimes Commission above n 73, 25

${ }^{131}$ See United Nations War Crimes Commission above n 73, 26. Buna is a type of synthetic rubber. The Buna Plant refers to the plants controlled by the Nazis during the Nazi era where forced labour were used in the Buna plants. The Buna plant during the Nazi era produced a great deal of rubber for Germany's needs at that time and the Buna plant was also used to produce oil from coal.

${ }^{132}$ See United Nations War Crimes Commission above n 73, 27

${ }^{133}$ Ibid

${ }^{134}$ Ibid

${ }^{135}$ United Nations War Crimes Commission above n 73,26,27

${ }^{136}$ United Nations War Crimes Commission above n 73,28

${ }^{137}$ Ibid

${ }^{138}$ Ibid
} 
opportunity the defendants had to evade the labour authorities of the Reich and if the evasion happened what would the consequences be. ${ }^{139}$ The Tribunal stated that there was a real possibility that if these officials had refused slave labour it could result in a retaliation that was drastic. ${ }^{140}$ On the issue of the defence of necessity the tribunal also relied on the reasoning of the International Military Tribunal (IMT) which had stated that a defendant cannot be absolved of responsibility because he followed superior orders however this fact could be used in mitigation to obtain a less severe punishment. ${ }^{141}$ The tribunal concluded that the defence of necessity cannot be invoked by officials who had themselves initiated the slave labour programme, who was responsible for the existence of the slave labour programmes or who executed the slave labour programmes. ${ }^{142}$ The defence of necessity prevailed for some of the officials but not all. ${ }^{143}$ The Tribunal found that some of the officials of Farben had exercised their own initiative in the procurement of the slave labours and that some of the officials of Farben had embraced and took full advantage of the slave labour programme. ${ }^{144}$ The Tribunal in finding some of the officials of Farben guilty of the crime of slave labour stated that:- ${ }^{145}$

It is plain therefore, that Hermann Roechling, von Gemmingen, and Rodenhauser, like Weiss and Flick were not moved by a lack of moral choice, but on the contrary , embraced the opportunity to take full advantage of the slave labour programme. Indeed, it might be said that they were, to a very substantial degree, responsible for broadening the scope of that reprehensible system.

Count Three shows Farben the Corporation as the perpetrator of the crime as well. ${ }^{146}$ Under count three the defendants were charged "individually, collectively and acting through the instrumentality of Farben" ${ }^{\text {147 }}$ for committing

\footnotetext{
139 Ibid

140 Ibid

${ }^{141}$ United States Of America v Carl Krauch And Twenty Two Others above n 37,1179

142 Ibid

${ }^{143}$ For instance the Tribunal found that Carl Krauch and Ter Meer had taken active steps to obtain slave labour and they were found guilty under this count of crime.

${ }^{144}$ United Nations War Crimes Commission above n 73, 27,28

${ }^{145}$ United States of America $v$ Carl Krauch And Twenty Two Others above n 37,1179

${ }^{146}$ See United States Of America $v$ Carl Krauch And Twenty Two Others above n 37,1167

147 Ibid
} 
war crimes and crimes against humanity. ${ }^{148}$ On the pivotal role that Farben played in the slave labour programme the Tribunal stated that:- ${ }^{149}$

The prosecution does not contend that Farben instituted a slave labour program of its own. On the contrary, it is the theory of the prosecution that the defendants, through the instrumentality of Farben and otherwise, embraced, adopted, and executed the forced labour policies of the Third Reich, thereby becoming accessories to and taking a consenting part in the commission of war crimes and crimes against humanity in violation of Article II of Control Council Law No.10

At the conclusion of the trial the US Military Tribunal found four of the officials of IG Farben guilty of the crime against humanity of slave labour. ${ }^{150}$ Officials such as Carl Krauch and Ambros were found guilty as Ambros went to the Auschwitz camp twice a year to obtain information with regards to the construction of the project and Krauch was found guilty because he was involved in the allocation of concentration camp inmates. ${ }^{151}$

The punishment meted out on these officials found guilty of plunder and slave labour involved prison terms of less than ten years. ${ }^{152}$ These short prison terms given by the Tribunal to these industrialists was too lenient in comparison to the crimes these industrialists were complicit in. On a legal premise the reason behind the short prison terms could be due to the defences of coercion and necessity relied on by these corporate officials. ${ }^{153}$ However the short prison terms given by the Tribunal to the industrialists could have been motivated by economic factors as well. ${ }^{154}$ These industrialists were millionaires during their era and they had vast business connections not only in Germany but in the world at large for instance Farben had links with 500 foreign firms. ${ }^{155}$ Prior to World War II IG

\footnotetext{
148 Ibid

${ }^{149}$ United States Of America v Carl Krauch And Twenty Two Others above n 37,1172

${ }^{150}$ United States Of America v Carl Krauch And Twenty Two Others above n 37,1196

${ }^{151}$ United States Of America $v$ Carl Krauch And twenty Two Others above n 37,1187,1193

${ }^{152}$ See United States Of America v Carl Krauch And Twenty Two Others above n 37, 1153-1196

${ }^{153}$ See United Nations War crimes Commission above n 73, 28

${ }^{154}$ See Anthony C. Sutton Wall Street and the Rise of Hitler (GSG Publishers, 2002) 34

155 Ibid
} 
Farben had very strong business links with the United States. ${ }^{156}$ As such the short prison terms given by the Tribunal to the industrialists is a reflection of the economic priorities of the United States that prevailed. United States was aware that World War II had ended but their business links with Germany will continue long after the war had ended.

\section{$5 \quad$ The significance and implication of the IG Farben decision}

The IG Farben decision under count two and three is significant in a few aspects. Firstly prior to World War II only states were subjects under International Law. ${ }^{157}$ However post the IG Farben decision individuals were held to be liable for the breaches under International Law. ${ }^{158}$ Principle I of the Principles of Nuremberg states that "any person who commits an act which constitutes a crime under international law is responsible therefore and liable to punishment"159 Secondly an individual would still be guilty under international law although the said individual had acted based on the orders of the government. ${ }^{160}$ Principle IV of the Principles of Nuremberg states that "The fact that a person acted pursuant to order of his Government or of a superior does not relieve him from responsibility under International law, provided a moral choice was in fact possible to him." ${ }^{\prime 61}$ Thirdly the IG Farben decision also held that individuals such as corporate officials and businessmen were also subjects under International Criminal Law. ${ }^{162}$ Fourth corporate officials also have legal obligations under International Criminal law. ${ }^{163}$ Fifth the theory of complicity was used to link these corporate officials to war crimes and crimes against humanity which meant that corporate officials could also be liable for war crimes and crimes against humanity by being complicit with the state in the commission of international

\footnotetext{
156 Ibid

${ }^{157}$ Before World War II no individuals were indicted for international crimes

${ }^{158}$ See Principle I of the Nuremberg Principles. International Humanitarian Law-Principles Nuremberg Tribunal 1950 www.icrc.org (accessed 30 June 2010)

159 Ibid

${ }^{160}$ See Principle II of the Nuremberg Principles.International Humanitarian Law-Principles Nuremberg Tribunal 1950www.icrc.org (accessed 30 June 2010)

161 Ibid

${ }^{162}$ Anita Ramasastry above n39, 98,99

163 Ibid
} 
crimes. ${ }^{164}$ Sixth due to the circumstances surrounding the actions of these officials the defences of coercion and necessity were taken into account by the Tribunal to reduce the sentences or in some cases to acquit them. ${ }^{165}$ Seventh the Tribunal had made statements that the corporation had committed the crimes and that the corporation was used by the officials to commit the crimes. ${ }^{166}$

\section{E The Krupp Trial}

Alfried Krupp was the sole owner of the Krupp enterprise and to Alfried Krupp business was all about making the profits, as indicated in his own words:- 167

....We thought that Hitler would give us such a healthy environment. Indeed he did do that.We Krupps never cared much about political ideas. We only wanted a system that worked well and allowed us to work unhindered. Politics is not our business.

\section{The indictments}

The Krupp case ${ }^{168}$ involved the indictment of 12 executives from the Friedrich Krupp Company ${ }^{169}$ for inter alia "war crimes and crimes against humanity"170

\section{The offences committed by the Krupp firm under count two (plunder)}

The Prosecution in this case had argued that the Krupp firm had committed plunder in relation to the Austin factory in France. ${ }^{171}$ The Austin factory at Liancourt France was taken over by the German army as soon as Germany

\footnotetext{
${ }^{164}$ See Principle VII of the Nuremberg Principles.International Humanitarian Law-Principles Nuremberg Tribunal 1950www.icrc.org (accessed 30 June 2010)

${ }^{165}$ See United Nations War Crimes Commission above n 73, 28

${ }^{166}$ United States of America v Carl Krauch And Twenty Others above n 37,1172

${ }^{167}$ The Nuremberg Trial $60^{\text {th }}$ Anniversary http://www.adl.org/education/dimensions 19/section3/krupp.asp (accessed 20 March 2009)

${ }^{168}$ United States Of America v Alfried Krupp Von Bohlen Und Halbach, Ewald Oskar Ludwig Loeser,Eduard Houdremont,Erich Mueller,Friedrich Wilhelm Janssen,Karl Heinrich Pfirsch, Max Otto Ihn,Karl Adolf Ferdinand,Heinrich Leo Korschan, Friedrich von Buelow, Werner Wilhel Heinrich,Hans Albert Gustav, (1952) IX, Trials Of War Criminals Before The Nuremberg Military Tribunals

${ }^{169}$ Case 10, The Krupp Case http://www.ushmm.org/wlc/article (accessed 1 April 2009)

${ }^{170}$ Anita Ramasastry above n 39,108

${ }^{171}$ United Nations War Crimes Commission above n 73, 85
} 
occupied France in $1940 .{ }^{172}$ Soon a provisional administrator was elected by the German authority to operate the plant although this act was not consented to by the owner of the plant. ${ }^{173}$ Subsequently the Krupp firm offered to buy the plant for 5 million francs. ${ }^{174}$ Then the provisional administrator was directed by German authorities to lease the Plant to the Krupp firm, and a lease of three years was given to the Krupp firm. ${ }^{175}$ Subsequently the firm purchased almost all the machineries at the Austin plant for a an extremely low price and the plant was taken over by the Krupp firm and they manufactured parts to be used in other Krupp factories in Germany and France and these machineries were largely used for the German war effort. ${ }^{176}$

The Krupp firm had also profited by anti Jewish laws by selecting as its office in Paris a property that was owned by Jews. ${ }^{177}$ To secure the lease to this property the Krupp firm dealt with the Provisional Administrator of Jewish properties and secured a lease for six months and after this period the Krupp firm could purchase the property. ${ }^{178}$ All these acts were done without the consent of the lawful owners of the property. ${ }^{179}$

As part of their defence to the indictment of plunder the officials of the Krupp firm argued that the Hague Convention IV and the regulations annexed to it was not applicable to situations where there was "total war" 180 The Tribunal rejected this defence and it held that Germany was a party to the Hague Convention IV of 1907 and by the year 1939 Hague Conventions had attained the status of Customary Law and as such Germany was bound by the Hague Convention IV and its regulations by way of treaty law and customary law. ${ }^{181} \mathrm{~A}$ further defence that was put forth by the officials of Krupp was that where a territory is occupied by belligerents, then the laws and customs of war does not

\footnotetext{
${ }^{172}$ Ibid

${ }^{173}$ United Nations War Crimes Commission above n 73, 86

${ }^{174}$ Ibid

${ }^{175}$ Ibid

${ }^{176}$ Ibid

${ }^{177} \mathrm{Ibid}$

${ }^{178}$ Ibid

${ }^{179} \mathrm{Ibid}$

${ }^{180}$ United States Of America v Alfried Krupp And Eleven Others above n 168,1340

${ }^{181}$ Ibid
} 
prohibit the seizure and exploitation of property where the transfer of the title of property has not been completed. ${ }^{182}$ The Tribunal termed this defence an "erroneous contention" and rejected the defence. ${ }^{183}$ The Tribunal asserted that Article 46 of the Hague Regulations was very clear which stated inter alia that private properties "must be respected" and "cannot be confiscated."184 Therefore if a factory is taken away from its owner but the transfer of title was not completed however since the owner was deprived of his enjoyment and rights over the property this would still be a contravention of Article 46 of the Hague Regulations. $^{185}$

\section{The judgment of the tribunal under count two}

The Tribunal stated that the acts of the Krupp firm in France and other territories amounted to plunder and the actions of the officials of the Krupp firm had contravened Articles 46, 52 and 53 of the Hague Regulations. ${ }^{186}$ Article 46 states that private properties "cannot be confiscated" and "must be respected.",187 The officials of the Krupp firm had contravened Articles 46 when the officials of the Krupp firm had inter alia taken machineries from factories in France. ${ }^{188}$ Article 52 of the Hague Regulations states that the requisition by the army in occupation should only be for the "needs of the army of occupation." "189 This Article was contravened as the officials of the Krupp firm had exploited and looted properties such as machinery and shares which was over and above what the German army needed. ${ }^{190}$ Article 53 states that the army in occupation can

\footnotetext{
${ }^{182}$ United States Of America v Alfried Krupp And Eleven Others above n 168, 1345

183 Ibid

${ }^{184}$ See Convention (IV) respecting the Laws and Customs of War on Land and its annex: Regulations concerning the Laws and Customs of War on Land. The Hague, 1907 ( adopted on 18 October 1907,entered into force 26 January 1910) art 46

${ }^{185}$ United States of America v Alfried Krupp And Eleven Others above n 168, 1345

${ }^{186}$ United States of America v Alfried Krupp And Eleven Others above n 168, 1340.Also See Convention (IV) respecting the laws and Customs of War on Land and its annex : Regulations concerning the Laws and Customs of War on Land.The Hague, 1907 , above n 184, art 46, 52, 53

${ }^{187}$ Convention (IV) respecting the laws and Customs of War on Land and its annex : Regulations concerning the Laws and Customs of War on Land.The Hague, 1907 ,above n 184, art 46

188 See United Nations War Crimes Commission above n 73, 88

${ }^{189}$ Convention (IV) respecting the laws and Customs of War on Land and its annex : Regulations concerning the Laws and Customs of War on Land.The Hague, 1907 , above n 184, art 52

${ }^{190}$ See United Nations War Crimes Commission above n 73, 85,86
} 
seize cash and other goods which could be used for the operations of the military $^{191}$ and restoration and compensation has to be made when peace is restored. ${ }^{192}$ Here the officials of the Krupp concern had looted property which was not for purposes of military operation but to expand their own private enterprises and businesses. ${ }^{193}$ Further there was no evidence that these properties would be restored when peace was reached as many of the transfers of title were permanent and not temporary. ${ }^{194}$

Out of the ten officials of the Krupp firm who were charged for the crime of plunder and spoliation under count two, at the conclusion of the trial, the Nuremberg Military Tribunal found six guilty and four were found not guilty. ${ }^{195}$

$4 \quad$ The offences committed by the Krupp firm under count three (slave labour)

Through the evidence adduced by the defence and the prosecution it was shown that throughout the industry in Germany generally and throughout the Krupp firm and its subsidiaries specifically, prisoners of war were made to work in armament production. ${ }^{196}$ Evidence showed that prisoners of war were made to work in the coal mines despite the fact they were unfit and unhealthy, that Russian prisoners of war and the Italian militia internees were force to do work although they were suffering from starvation. ${ }^{197}$ Further evidence adduced showed that the Krupp firm had made use of illegal foreign workers and these workers were forced to sign contracts which stated that they would work in the Krupp firm, their refusal to sign these contracts would lead to them being sent to penal camps. ${ }^{198}$ Further evidence was given which showed that the subordinates of the accused Lehmann, one of the officials of the Krupp firm were sent to the

\footnotetext{
191 Ibid

${ }^{192}$ Convention (IV) respecting the laws and Customs of War on Land and its annex : Regulations concerning the Laws and Customs of War on Land.The Hague, 1907 ,above n 184, art 53

193 See United Nations War Crimes Commission above n 73, 85-88

${ }^{194}$ United Nations War Crimes Commission above n 73,88

195 See United States Of America v Alfried Krupp And Eleven Others above n 168, 1449-1451

${ }^{196}$ United nations War Crimes Commission above n 73, 93

197 Ibid

198 Ibid
} 
occupied territories to secure workers for the Krupp firm. ${ }^{199}$ Further at Berthawerke camp in the Krupp firm's quest to expand its business it had used slave labourers. ${ }^{200}$

The officials of the Krupp firm also raised the defense of necessity which was also raised in the IG Farben case where the Krupp officials alleged that they were forced to reach the quotas set by the Third Reich and therefore it was necessary for these slave labourers to have been used in factories and various other enterprises. ${ }^{201}$ The Tribunal responded to this defence of necessity by stating that: ${ }^{202}$

Necessity is a defense when it is shown that the act charged was done to avoid an evil severe and irreparable, that there was no other adequate means of escape and that the remedy was not disproportionate to the evil"

In addressing the issue of the defence of necessity the Tribunal stated that the choice that the officials of Krupp firm made turned out to be favourable to themselves with terrible consequences to the prisoners of war who had no say in the situation. ${ }^{203}$ The tribunal further inquired what would have happened had the officials of the Krupp firm swayed away from the Reich's policies. ${ }^{204}$ The Tribunal reasoned that one of the possible consequences would be that their officers would have lost their jobs. ${ }^{205}$ Furthermore they reasoned that where Krupp was concerned Krupp may have lost his plant. $^{206}$ The Tribunal also noted the possibility that these officers could have been sent to the concentration camp had they acted in contravention of the Reich's policies. ${ }^{207}$ However the Tribunal

\footnotetext{
${ }^{199}$ United States Of America v Alfried Krupp And Eleven Others above n 168, 1440

${ }^{200}$ United Nations War Crimes Commission above n 73, 101

${ }^{201}$ United States Of America v Alfried Krupp And Eleven Others above n 168, 1445

${ }^{202}$ United Nations War Crimes Commission above n 73,147

${ }^{203}$ United States Of America v Alfried Krupp And Eleven Others above n 168, 1445

204 Ibid

205 Ibid

206 Ibid

${ }^{207}$ Ibid
} 
reasoned that this possibility was remote as Alfried Krupp enjoyed close ties with Hitler. $^{208}$

\section{The judgment of the tribunal under count three}

Twelve officers of the Krupp firm were charged under count three for the crime of slave labour and eleven were found guilty of this crime. ${ }^{209}$

In the judgment the Tribunal had made various references to the Krupp firm and stated that the firm had desired the use of slave labour ${ }^{210}$ and had on its own committed the slave labour offences. ${ }^{211}$ The tribunal remarked that "the situation at the Berthawerk again leads to the conclusion that the Krupp firm planned its own program upon its desire to use concentration camp labour." ${ }^{, 212}$ It was the finding of the tribunal that the use of the slave labours and the various slave labour programmes had benefited the Krupp firm. ${ }^{213}$

\section{The significance and implication of the Krupp decision}

A significant point raised by the tribunal in relation to the crime of slave labour is the issue of benefit. ${ }^{214}$ The Tribunal stated that the Krupp firm had benefited from a programme which had forced 30,000 workers that were skilled in the trade of producing iron to come to Germany. ${ }^{215}$ The Tribunal further held that the horrors that occurred at the concentration camps are well known and that "the Krupp firm was the beneficiary of these camps." 216 The decision in the case of Krupp in relation to the crime against humanity of slave labour would stand for the proposition that if the officials of a firm had benefited from the crime of slave labour then they would be found guilty of the crime of slave labour. ${ }^{217}$ It is arguable that based on the reasoning of the Tribunal in the Krupp case it could be

\footnotetext{
208 Ibid

${ }^{209}$ United States Of America v Alfried Krupp And Eleven Others above n 168, 1449-1451

${ }^{210}$ Anita Ramasastry above n 39,112

211 Ibid

${ }^{212}$ United States Of America v Alfried Krupp And Eleven Others above n 168, 1423

${ }^{213}$ United States Of America v Alfried Krupp And Eleven Others above n 168,1411

214 Ibid

${ }^{215}$ United States Of America v Alfried Krupp And Eleven Others above n 168, 1398

${ }^{216}$ United States Of America v Alfried Krupp And Eleven Others above n 168, 1411

217 Ibid
} 
argued that when TNCs act in collaboration with a repressive regime and uses forced labour and if the TNCs reap benefits as a result of the forced labour that is used then the TNCs could be guilty under the law for the crime of slave labour. It is arguable that the decision in the Krupp case could also stand for the proposition that the ambit of liability of economic actors such as officials of TNCs that joins forces with a repressive government is not only limited to situations where slave labour is employed but the law laid down in the Krupp case could encompass situations whereby a repressive regime partners with an economic actor and if through the partnership violations of the law take place and both parties garner benefits from the violation of these laws then both parties should be found guilty under the law for the violation of the said laws.

In sentencing Krupp to twelve years imprisonment the Tribunal had also ordered that his property both real and personal is to be forfeited. ${ }^{218}$ However the punishment given by the Tribunal concerning the forfeiture of Krupp's property was only temporary as after three years this mandate concerning the forfeiture of his property was reversed due to the intervention New York banker and statesman John J.McCloy. ${ }^{219}$ As such the punishment given by the Tribunal to Krupp in relation to the forfeiture of his property was merely a paper judgement which carried little weight in reality. This type of punishment which includes forfeiture of assets or properties belonging to corporate officials could prove to be a deterrent factor which may stop or at least greatly reduce many corporate officials and corporations from being complicit in war crimes and crimes against humanity. In theory such punishments are desirable but practically it may encounter certain challenges and problems for instance what would happen to the properties of the corporate officials that has been confiscated. Even if these problems can be circumvented it has to be ensured that judgments concerning forfeiture of properties of corporate officials are not merely paper judgements but judgments that take effect in reality where no individual or government should be given the

218 "Nuremberg Trials 60 ${ }^{\text {th }}$ Anniversary" (2006) Dimensions Journal of Holocaust Studies Also See 1945-1953-Krupp After The war www.globalsecurity.org/military (last accessed 10 July 2010)

219 See Garrick Utley “John J. McCloy and the "Splendid Reconciliation” 1 
liberty or authority to reverse the judgment that has been given by the court at the conclusion of a full trial.

Although the Nuremberg Trial should be applauded as there were many breakthroughs in many areas of the law such as individuals being indicted and found guilty for international crimes and corporate officials being indicted and found guilty of crimes against humanity and war crimes. ${ }^{220}$ However there were many weaknesses in the Nuremberg trials such as individuals being allowed to reverse the decisions pronounced by the court. ${ }^{221}$ All these apparent weaknesses of the Nuremberg trial has prompted some critics to term the Nuremberg trial as "Victor's justice" and merely a show trial. ${ }^{222}$

\section{F The Flick Trial}

Six officials of the Flick firm were indicted for the crime of slave labour (count one) and under count two for pillage and spoliation of properties. ${ }^{223}$

\section{Judgment of the tribunal under count one (slave labor)}

The tribunal held that it recognised that under this count the origin of the slave labour programme found its roots in the government of the Reich and the tribunal held that the defendants "224 "had no part in creating or launching this program". ${ }^{225}$ The tribunal further held that from the evidence that was adduced it was clear that the defendants had no 226 "actual control of the administration of

\footnotetext{
${ }^{220}$ See United States Of America v Carl Krauch And Twenty Two Others above n 37,1156,111591160,1196

${ }^{221}$ See 1945-1953-Krupp After the War-www.globalsecurity.org/military (accessed 12 July 2010)

${ }^{222}$ See Joseph Brunner "American Involvement In The War Crimes Trial Process"4 Also see Salman Kazmi Is Victor's Justice in Nuremberg Trial Justified or not? 3,4

${ }^{223}$ See United States Of America v Friedrich Flick,Otto Steinbrinck,,Odilo Burkart,Konrad Kaletsch,Bernhard Weiss, Hermann Terberger (1952) VI Trials Of War Criminals Before The Nuremberg Military Tribunals at 1194,1202

${ }^{224}$ United States Of America v Friedrich Flick And Five Others above n 223, 1196

${ }^{225}$ Ibid

${ }^{226}$ Ibid
} 
such program". ${ }^{227}$ The evidence showed that the programme was created and supervised by the state. ${ }^{228}$ In this case the defence also raised the defence of necessity and the court allowed this defence for four of the defendants. ${ }^{229}$ The tribunal stated that the defence of necessity was available to these men as if they did not follow the orders of the third Reich in relation to the slave labour programme they were in ${ }^{230}$ "clear and present danger."231 However two other defendants that is Flick and Weiss were found guilty under this count of indictment, as these two men had taken constructive steps for the procurement of prisoners for work and they had asked for the increase in the quota of freight cars $^{232}$ which would imply more prisoners were needed to do the jobs as such these two defendants were deprived of the defence of necessity. ${ }^{233}$

2 The Judgment of the tribunal under count two (plunder)

In 1940 the Rombach plant was an enterprise which dealt with inter alia blast furnaces and cement works. ${ }^{234}$ During World War II when Germany invaded France the Rombach plant was located in Alsace, Lorraine in France. ${ }^{235}$ The owners of the Rombach plant was a French Corporation. ${ }^{236}$ When Germany invaded Lorraine the German army issued a decree concerning orderly management. ${ }^{237}$ Subsequently public administrators were appointed for the Rombach plant and the contract was signed with the Flick firm and therefore the Flick firm took possession of the Rombach plant. ${ }^{238}$ The contract gave the Flick concern the status of a trustee only and the firm was to manage the Rombach plant on behalf of the Third Reich. ${ }^{239}$ Flick wanted to expand his organisation

${ }^{227}$ Ibid

${ }^{228}$ Ibid

${ }^{229}$ United States Of America v Friedrich Flick And Five Others above n 223, 1202

${ }^{230}$ United States Of America v Friedrich Flick And Five Others above n 223, 1201

${ }^{231}$ Ibid

${ }^{232} \mathrm{Ibid}$

${ }^{233} \mathrm{Ibid}$

${ }^{234}$ United Nations War Crimes Commission Trials of war Criminals Flick (UN War Crimes

Commission IX,1949) 10

${ }^{235}$ Ibid

${ }^{236}$ Ibid

${ }^{237}$ United Nation War Crimes commission above n 234, 11

${ }^{238}$ Ibid

${ }^{239}$ Ibid 
with another steel plant such as the Rombach plant. ${ }^{240}$ Therefore when the invasion of the allied occurred Flick added the Rombach property to his concern. $^{241}$ The tribunal noted that in dealing with property situated outside of his own state Flick should have been aware of the provisions of International law. ${ }^{242}$

Under count two for the offences of pillage, plunder and spoliation the tribunal found that only Flick was guilty of this offence. ${ }^{243}$ Since Flick in the management of the Rombach had with an intent to protect his interest in the property inserted a provision which would ensure that he will not lose any of his own capital. ${ }^{244}$ The tribunal found that although Flick did not commit the act of "systematic plunder", ${ }^{245}$ however Flick was never the less found to be criminally liable for the offence of plunder and spoliation by virtue of the fact that Flick had not respected private property and hence he was held to have violated article 46 of the Hague Regulations ${ }^{246}$ which states that private property "must be respected" and "cannot be confiscated." 247 The tribunal noted that the other Defendants Weiss, Burkatt and Kaletsch were only employees that were paid salaries and had no capital interest in the enterprises. ${ }^{248}$ Their role was limited to giving Flick advice and information and their conduct did not warrant any punishment. ${ }^{249}$

\section{The significance and implication of the Flick decision}

The case of Flick stands for the proposition that the defence of necessity would succeed in the event that the defendants can prove that they had absolutely no control over the use of slave labour and that it was in the exclusive control of

\footnotetext{
240 Ibid

${ }^{241}$ United States of America v Friedrich Flick And Five Others above n 223, 1207

242 Ibid

${ }^{243}$ United States Of America v Friedrich Flick And Five Others above n 223,1208

${ }^{244}$ United States Of America v Friedrich And Five Others above n 223, 1207

${ }^{245}$ United States Of America v Friedrich Flick And Five Others above n 223, 1208

246 Ibid

247 Convention (IV) respecting the laws and Customs of War on Land and its annex : Regulations concerning the Laws and Customs of War on Land.The Hague, 1907 , above n 184, art 46

${ }^{248}$ United States of America $v$ Friedrich Flick And Five Others above n 223,1208

${ }^{249}$ United States Of America v Friedrich Flick And Five Others above n 223,1209
} 
the State and secondly if they did not go along with the programme of slave labour they would be faced with a "clear and present danger" including death. ${ }^{250}$

The significance of the decision under count two lies in the fact that the tribunal found Flick guilty under count two although the tribunal said that he did not commit plunder that is systematic. ${ }^{251}$ As such following the provisions of the Hague regulations criminal liability for pillage, plunder and spoliation does not only arise when one does an active act that is plunder that is systematic but a person or arguably a corporation can be found criminally liable for an act that is construed as not respecting the property of another. As such a person or corporation that does an act that interferes with the property of another would be guilty for the crime of pillage.

\section{G The Third Reich in Germany and the Junta in Burma-The Differences}

The similarities between these two eras from a factual perspective will be dealt with first before going on to the significant differences between the era of the Third Reich and the Junta in Burma. Firstly both the leaders of the Third Reich and the Junta in Burma are well known for the atrocities that they had committed and reportedly still being committed where Burma is concerned. ${ }^{252}$ Secondly during the reign of the Third Reich a culture of impunity existed in Germany and in the territories that Germany conquered at that time and a culture of impunity is prevalent in Burma today as documented in various reports by the United Nations Special Rapporteurs to Burma. ${ }^{253}$ Thirdly the Third Reich had persecuted and killed millions of Jews, political prisoners, social undesirables and ethnic minorities from Germany and from other countries. ${ }^{254}$ The Junta in Burma uses the Tatmadaw that is the soldiers of the Junta army to kill thousands of their

\footnotetext{
${ }^{250}$ See United States of America v Friedrich Flick above n 223, 1196, 1201

${ }^{251}$ See United States Of America v Friedrich Flick And Five Others above n 223,1208

${ }^{252}$ See Adolf Hitler and The Holocaust www.auschwitz.dk/Hitler (accessed 12 July 2010)Also See HRC Resolution 10/27 above n 3, para 25,para 63, para 121. During the rule of the Third Reich millions of Jews and other were killed, in Burma a million people are displaced and thousands killed due to the policies practised by the Junta.

${ }^{253}$ See United Nations "Towards development, Security and Human Rights for All” (2005)

Yearbook of the United Nations, 811. Also See Report on HRC Resolution 10/27 above n 3, para 63

${ }^{254}$ See Robert A. Graham S.J “The Right To Kill” In The Third Reich. Prelude To Genocide.”(1976) 62 The Catholic Historical Review. 56,56
} 
own citizens comprising of the ethnic minorities and those who are working publicly for a democratic Burma. ${ }^{255}$ The inhumane policies of the Junta has resulted in the exodus of thousands of Burmese refugees into neighbouring countries such as Thailand and Malaysia and many countries such as New Zealand and United States have accepted some of these Burmese refugees. ${ }^{256}$

In each case the ordinary civil structures which might otherwise have protected the human rights of citizens were subordinate to military or paramilitary organisations. ${ }^{257}$ Lastly, in each case, power is condensed into the hands of a powerful and small oligarchy. ${ }^{258}$

However from a legal perspective, there are some differences between these two eras which are significant. Firstly under the rule of the Third Reich an international armed conflict was taking place in Germany as Germany had made aggressive war against other countries and had conquered territory in France, Poland and most of Europe, Scandinavia, the Balkans and parts of the Soviet Union. ${ }^{259}$ The Junta in Burma has not made aggressive war against other countries nor have they conquered any territories or countries outside Burma. ${ }^{260}$ It is the argument of this paper that the Junta in Burma have been involved in a prolonged armed conflict with many of the ethnic minorities inside Burma such as with the Shan and the Karen minorities, ${ }^{261}$ however this is clearly a conflict of a non international character, to which other parts of the law apply. ${ }^{262}$ The law applicable to international armed conflicts, such as Germany was going through

\footnotetext{
${ }^{255}$ HRC Resolution 10/27 above n 3, para 24,25

${ }^{256}$ Burmese people continue to leave country despite looming elections www.bnionline.net/news(accessed 14 July 2010)

${ }^{257}$ See Nazi Party 1934-1939 www.historyplace.com/worldwar2/triumph (accessed 14 July 2010)Also see New York Times “ Change comes to Myanmar,but only on the Junta's Terms.” (17 March 2010) 1

${ }^{258}$ In Germany during the Nazi era all power were vested in Hitler and his Generals. Today in Burma all power is vested in General Tan Shwe and his cronies. See Third Reich :Overview www.ushmm.org (accessed 14 July 2010) Also see Hannah Beech,Pyin U Lwin "Soldiers of Fortune" (26 July 2010) Time

${ }^{259}$ See David Sedivy "Germany WW I and WW II Overstretch"1

${ }^{260}$ Burma has no external enemies and they have business relations with its neighbours such as Malaysia, India, China and Thailand.

${ }^{261}$ See HRC Resolution 10/27, above n 3, para 66,para 67,para 69.Also See HRC Resolution 5/1 Human Rights Situation That Requires The Council's Attention (7 March 2008) A/HRC/7/18, para 77

${ }^{262}$ See report by Report on HRC Resolution 10/27 above $\mathrm{n} 3$ which states that armed conflict is still occurring in Burma.
} 
was derived from inter alia The Hague Regulations of $1907,{ }^{263}$ Prisoner of War Convention Geneva $1929^{264}$ customary international law as it stood in 1939-1945 and Article II of Control Council Law No.10 which only came into effect at the end of the Second World War. ${ }^{265}$ In Burma today since there is a non international armed conflict the law applicable would be inter alia Common Article III of the Geneva Conventions of $1949,{ }^{266}$ customary international law as it stands in the $21^{\text {st }}$ Century and the statute of the International Criminal Court. ${ }^{267}$ Although Burma has not ratified the Rome Statute, the United Nations Security Council could refer the case of Burma to the Prosecutor of the ICC. ${ }^{268}$ When a case is commenced this way the ICC would have jurisdiction over the crimes that are occurring in Burma although Burma has not ratified the Rome Statute. ${ }^{269}$ However the problem with exercising this option is that China and Russia has in the past vetoed resolutions concerning Burma. ${ }^{270}$

The second difference relates to the type of plunder that was committed during the Third Reich and that the type of plunder that this paper argues is being committed in Burma today. The Third Reich had plundered public and private properties which included factories and machineries in other countries that they had conquered such as in Poland, France and Norway. ${ }^{271}$ Further the act of plunder committed also encompassed legal forms but which was not legal as illustrated in the cases discussed above. ${ }^{272}$ The plunder arguably committed by the Junta is not directed outside of Burma but it is done within the country when

\footnotetext{
${ }^{263}$ Convention (IV) respecting the laws and Customs of War on Land and its annex : Regulations concerning the Laws and Customs of War on Land. The Hague ,1907, above n 184.

${ }^{264}$ Convention relative to the Treatment of prisoners of War. Geneva, 27 July 1929 (adopted on 27 July 1929)

${ }^{265}$ Control Council Law No .10 only came into effect at the end of World War II which has prompted critics to state that when the crimes were committed the laws such as control council no.10 was not in existence as such the laws were applied ex post facto.

${ }^{266}$ Convention (III) relative to the Treatment of Prisoners of War (12 August 1949) The

Convention was adopted on 12 August 1949

${ }^{267}$ See Rome Statute, above n 34.

${ }^{268}$ See Jennifer Elsea :International Criminal Court: Overview and selected Legal Issues (Report prepared for Congress 5 June 2002)

${ }^{269}$ Ibid

${ }^{270}$ Washington Post “ Russia, China Veto Resolution On Burma” (13 January 2007)

${ }^{271}$ See United States of America $v$ Carl Krauch And Twenty Two Others above n 37,1140

${ }^{272}$ Ibid
} 
the Junta destroys and confiscates the properties belonging to the people ${ }^{273}$ and where the Junta arguably exploits the natural resources in the country. ${ }^{274}$ At Nuremberg it was clear that the war crime of pillage had been committed and the industrialists contravened the Hague Regulations and some of the officials of the firm were found guilty of committing the war crime of pillage. ${ }^{275}$ In Burma today the acts done by the Junta such as destruction and confiscation of the people's property and exploitation of natural resources could also be termed as pillage ${ }^{276}$ as the acts of the Junta is in contravention of treaty laws such as the Hague Regulations $1907^{277}$ and Geneva Conventions $1949^{278}$ where Article 33 of the Geneva Convention IV states that "pillage is prohibited." 279 It is arguable that although these obligations only apply in conventional law in respect of international armed conflict, however the rules that they contain have now crystallised into customary international law which is now applicable to both international armed conflict and non international armed conflict. ${ }^{280}$

The third difference relates to the extent of slave labour that was used. During the Nazi era slave labourers were used extensively and most of the slave labourers in Germany at that time were prisoners of war from countries such as Poland and Russia. ${ }^{281}$ In Burma today there are slave labourers however these slave labourers in Burma are from within Burma. ${ }^{282}$ In Burma today slave labourers is used extensively and there is evidence that slave labourers are used especially in relation to the joint venture projects undertaken by the Junta in collaboration with the various TNCs. ${ }^{283}$

\footnotetext{
${ }^{273}$ See Report on HRC Resolution 10/27 above n 3, para 111

274 Ibid. The Special Rapporteur had stated that the depletion of resources in Burma was alarming.

${ }^{275}$ See United States of America v Alfried Krupp And Eleven Others above n 168, 1449-1451, some officials from IG Farben and Flick were also found guilty for the crime of plunder.

${ }^{276}$ See HRC Resolution 5/1 above n 261, para 64, para 65, para 66.

277 See Convention (IV) respecting the laws and Customs of War on Land and its annex: Regulations concerning the Laws and Customs of War on Land, 1907,above n 184.

${ }^{278}$ Convention (IV) relative to the Protection of Civillian Persons in Time of War Geneva , 12 August 1949 (adopted 12 August 1949, entered into force 21 October 1950)

279 See Convention (IV) relative to the Protection of Civilian Persons in Time of War. Geneva, 12 August 1949 (adopted on 12 August 1949),above n 278, art 33

${ }^{280}$ See Henckaerts and Doswald-Beck Customary International Humanitarian Law Volume 1(Cambridge, Cambridge University Press, 2005) 182-185

${ }^{281}$ See United Nations War Crimes Commission above n 73, 27,93

${ }^{282}$ See Summary of Report on HRC Resolution 10/27 above n3, at 2

${ }^{283}$ See Report on HRC Resolution 10/27 above n 3, para 111
} 
Fourthly the Third Reich wielded power that extended to other territories and countries, ${ }^{284}$ the tribunal held that that the industrialists had aided and abetted the Third Reich in committing war crimes and crimes against humanity. ${ }^{285}$ The atrocities that the Third Reich committed involved the people within their own country and the citizens of other countries which is not the case in the situation in Burma. ${ }^{286}$ In Burma the atrocities of the Junta are directed solely against the citizens of the country itself. ${ }^{287}$

\section{H The Legal Principles Derived from the Industrialists Trials at Nuremberg}

Amongst the principles enunciated at Nuremberg one of the most important is that private actors such as officials of corporations are also subjects under international criminal law and they have international law obligations. ${ }^{288}$ When these International law obligations are contravened they could be guilty for war crimes and crimes against humanity and thus be found guilty under International Criminal Law. ${ }^{289}$

Secondly the theory of complicity was used to attach guilt on these corporate officials for having aided and abetted the Third Reich in committing war crimes and crimes against humanity. ${ }^{290}$

Third war crimes such as plunder was given a wide definition as illustrated above. ${ }^{291}$ Officials of corporations were held liable for the war crime of plunder

\footnotetext{
${ }^{284}$ Germany under the Nazi rule had extended its territories to inter alia Norway, Poland and France

${ }^{285}$ See United States Of America v Carl Krauch And Twenty Two Others above n 37, 1153

${ }^{286}$ See United States Of Amerca v Carl Krauch And Twenty Two Others above n37,1140. Burma on the other hand has no external enemies outside of its own country and it maintains thriving business relationships with its neighbors such as India, China and Malaysia.

${ }^{287}$ See HRC Resolution 10/27 above n 3, para 121

${ }^{288}$ United Nations "Text of the Nurnberg Principles Adopted by the International Law Commission" "Formulation of the Nurnberg Principles" (1950,volume 2) Yearbook of International Law Commission 374-378, principle I

${ }^{289}$ See United Nations "Text of the Nurnberg Principles Adopted by the International Law Commission" above n 280, Principle VI.

${ }^{290}$ See United Nations "Text of the Nurnberg Principles Adopted by the International Law Commission" above n 280,Principle VII.

${ }^{291}$ See United States Of America v Carl Krauh And Twenty Two others above n 37, 1140
} 
when their actions contravened provisions of the Hague Regulations in particular Articles 46, 52 and $53 .^{292}$

Fourth in Nuremberg the officials who were found guilty were the officials who had done positive acts in relation to the crime of plunder either by "ordering, authorizing, approving" or taking part in policies that was criminal. ${ }^{293}$ For transactions that were legal in form but illegal in effect the corporate officials had knowledge that the owner was being deprived of his property against his will and the military was a threat that was always present during negotiations. ${ }^{294}$

Fifth private actors such as officials of corporations could be found guilty of crimes against humanity for actions such as employing slave labour in their factories. ${ }^{295}$ The defence of necessity will only prevail if the officials of the firms proved that they were in "clear and present danger" if they did not use forced labour in their plants. ${ }^{296}$ The officials of the firm who were ultimately found guilty of the crime against humanity of slave labour are those who had initiated the slave labour programme, recruited slave labour and who were responsible for allocating slave labour to the camps. ${ }^{297}$

Sixth the Nuremberg Tribunals demonstrated that legal persons such as corporations could be used by natural persons as an instrument to commit plunder and slave labour. $^{298}$

\section{Lessons from Nuremberg and the Situation in Burma}

In Burma today a repressive regime in the form of a military junta rules the country. ${ }^{299}$ The Junta in Burma is kept in power mainly due to the private actors such as the officials of TNCs and in particular TNCs that are the joint venture project partners with the Junta for the extraction of natural resources in Burma. ${ }^{300}$

\footnotetext{
292 See United States Of America v Alfried Krupp And Eleven Others above n 168, 1340

${ }^{293}$ See United States Of America v Carl Krauch And Twenty Two Others above n 37, 1157 294 Ibid

${ }^{295}$ United States Of America v Carl Krauch And Twenty Two Others above n 37, 1196

${ }^{296}$ See United States Of America v Friedrich Flick And Five Others above n 223,1201

${ }^{297}$ See United States Of America v Carl Krauch And Twenty Two others, above n 37,I179

${ }^{298}$ See United States Of America v Carl Krauch And Twenty Two others above n 37,1172

${ }^{299}$ See New York Times above n 257

${ }^{300}$ The Junta obtains massive revenues from collaborating in business deals with the TNCs. See HRC resolution 10/27 above $n$ 3, para 102
} 
Officials of TNCs in Burma are subjects under International Criminal Law and they do have International Law obligations. ${ }^{301}$ It is arguable that when these international obligations are contravened by the officials of TNCs in Burma then they could be liable for war crimes and crimes against humanity under International Criminal Law.

\section{J The Industrialists Cases at Nuremberg and the Officials of TNCs In Burma}

Despite the atrocities that the Nazis committed they were able to survive due to the economic assistance rendered to them by these economic giants, IG Farben, Krupp and Flick, for instance on one occasion on Hitler's request for financial assistance Farben had given Hitler 400,000 Reichmarks ${ }^{302}$ The Nuremberg tribunal saw the significance that these economic enterprises played during the Nazi era hence their indictments. ${ }^{303}$ The Third Reich assisted these economic actors by providing them with slave labour and granting them the passage to commit crimes such as spoliation and plunder. ${ }^{304}$ As such the Third Reich and these economic actors had a very rewarding partnership and they were inextricably connected to each other and dependent on each other for mutual benefits but the losing party in this circle of mutual benefits were the Jews and the citizens of the territories occupied by Germany. ${ }^{305}$ As Presiding Judge Sears noted the role played by the industrialists "Krupp, Flick Thyssen, and a few others swayed the industrial group; On the shoulders of these groups Hitler rode to power, and from power to conquest."

More than half a century later the same sequence of events is being repeated in countries such as Burma. The various TNCs in Burma in the view of this author, have taken the place of IG Farben, Krupp and Flick. These TNCs are the

\footnotetext{
${ }^{301}$ See Principle I of the Nuremberg Principles. International Humanitarian Law-Principles Nuremberg Tribunal 1950www.icrc.org (accessed 30 June 2010)Also see Anita Ramasastry above n39, 98,99

${ }^{302}$ United States Of America v Carl Krauch And Twenty Two Others above n 37,17

303 Ibid

${ }^{304}$ United States Of America v Carl Krauch And Twenty Two Others above n 37,19

${ }^{305}$ Victims of the Nazi era : Nazi Racial Ideology www.ushmm.org (accessed 14 July 2010) Millions of Jews and others were killed due to the policies of the Third Reich

${ }^{306}$ United States Of America v Friedrich Flick And Five Others above n 223,1191
} 
life line of the Junta regime in Burma. ${ }^{307}$ and helps the Junta maintain its power in Burma. ${ }^{308}$ Telford Taylor one of the lead prosecutors of the war crimes at Nuremberg stated that: ${ }^{309}$

Without IG Farben, the Second World War would not have been possible. These corporate executives-not the Nazi hooligans -were the real culprits. If the crimes they committed are not brought to the light of the day, they will commit even bigger crimes in future generations.

The words of Telford Taylor were relevant for the Nazi era and are still relevant today to TNC's that partners with repressive regimes. At the Nuremberg trial the Tribunal were convinced of the truth that Hitler by himself could not have committed all the atrocities that were done during the reign of the Third Reich, but the atrocities that originated in Hitler's mind were put into action with the help of various persons that included businessmen. ${ }^{310}$ At the Nuremberg trial the Tribunal stated that:- ${ }^{311}$

...Hitler could not make aggressive war by himself. He had to have the cooperation of statesmen, military leaders, diplomats and businessmen. When they, with knowledge of his aims, gave him their cooperation, they made themselves part to the plan he had initiated. They are not to be deemed innocent because Hitler made use of them, but they knew what they were doing. That they were assigned to their tasks by a dictator does not absolve them from responsibility for their acts. The relation of leader and follower does not preclude responsibility here any more than it does in the comparable tyranny of organized domestic crime.

\footnotetext{
${ }^{307}$ See for example Amy Goodman "Chevron's pipeline Is Regime's Lifeline” (8 October 2007) The Daily Camera, Colorado

${ }^{308}$ Ibid

${ }^{309}$ See The Bigger Picture "The Origin Of Pharmacuetical Colonialism" 146

${ }^{310}$ See United States Of America v Carl Krauch And Twenty Two Others above n 37,100.IG Farben was a huge Transnational Corporation during the Nazi era and IG Farben was crucial to the survival of the Third Reich, Today in Burma TNCs are keeping the Junta in power as well.

${ }^{311}$ See United States Of America v Carl Krauch And Twenty Two Others above n 37,495
} 
"The Farben leaders and other industrialists saw the Nazi movement growing and saw in it the opportunity to extend their economic dominion." 312 Today TNCs in Burma eager for economic profits are assisting the junta in Burma ${ }^{313}$ who are well known for their human rights abuses and violations of the law. ${ }^{314}$

\section{K Conclusion}

In their judgments the tribunal had given great importance on the role played by the corporations and officials of corporations in the commission of war crimes and crimes against humanity. ${ }^{315}$ In the IG Farben case the firm was referred to as the instrument that was used to commit the crimes and the Tribunal went on to say that the firm IG Farben itself had committed the crime of plunder and spoliation and in the case of Krupp the firms were also said to be the beneficiary of the crimes committed. ${ }^{316}$ It can be inferred from the judgment of the United States Military Tribunal that the Tribunal would have held the firms itself guilty for war crimes and crimes against humanity but they were unable to do so as their jurisdiction were limited to confer liability only on natural persons and not on legal persons. ${ }^{317}$ The potential liability of the officials of TNCs in Burma under International Criminal Law is analysed in chapters IV and V.

\footnotetext{
312 United States Of America v Carl Krauch And Twenty Two Others above n 37, 16

${ }^{313}$ See Hannah Beech above n 19 where its states that Transnational Corporations are doing business in Burma with the Junta however these joint ventures have no benefit to the people in Burma.

${ }^{314}$ The Junta rules Burma where there is a culture of impunity. See HRC Resolution 10/27 above $\mathrm{n}$ 3,para 121

${ }^{315}$ United States of America v Carl Krauch And Twenty Two Others above n 37,1172

${ }^{316}$ Ibid.Also See United States Of America v Alfried Krupp And Eleven Others above n 168,1411

${ }^{317}$ United States Of America v Carl Krauch And Twenty two Others above n 37, 1172
} 


\section{AN ASSESSMENT OF THE POTENTIAL LIABILITY OF THE OFFICIALS OF TRANSNATIONAL CORPORATIONS IN BURMA FOR THE CRIME AGAINST HUMANITY OF ENSLAVEMENT UNDER INTERNATIONAL CRIMINAL LAW}

In this chapter the liability of the officials of TNCs in Burma under International Criminal Law for being complicit by aiding and abetting the Junta Regime in the commission of crimes against humanity of enslavement will be analyzed. In doing this analysis firstly the situation in Burma will be looked at to ascertain whether the crime against humanity of enslavement is being committed in Burma by the Junta Regime. Subsequently the role of the TNCs and the officials of the TNCS in the commission of this crime will be analyzed. Subsequent to this the analysis will be focused on whether the officials of TNCs in Burma could be liable under International Criminal Law for being complicit by aiding and abetting the Junta regime in Burma for the crime of enslavement. In doing this analysis the developing Jurisprudence on complicity and aiding and abetting ranging from the Nuremberg cases to ICTY cases will be used to analyze and ascertain the possible liability of officials of TNCs in Burma for the crime of enslavement under International Criminal Law.

\section{A The Development of the Crime of Enslavement}

Article 1 of the Slavery Convention which was signed in Geneva on the 25th September 1926 defines slavery as "the status or condition of a person over whom any or all of the powers attaching to the right of ownership are exercised." 318

At the Nuremberg Trial enslavement was a crime against humanity under Control Council Law No.10 $10^{319}$ The crime of enslavement/forced labour is found in the statute of the International Criminal Tribunal for former Yugoslavia (ICTY)

\footnotetext{
${ }^{318}$ Slavery Convention, Geneva, 25 September 1926 (adopted 25 September 1926 , entered into force 9 March 1927) art 1. Also See Forced Labour Convention 1930,Geneva (adopted 28 June 1930, entered into force 1 May 1932) art 2.1

${ }^{319}$ See United States Of America v Alfried Krupp And Eleven Others above n 168, 1373
} 
(Article 5 ( c) ), the International Criminal Tribunal for Rwanda (ICTR) (Article 3

(c) ) of ICTR and the crime of enslavement is now set out in the Rome Statute as a crime against humanity under Article 7 (1) (c). ${ }^{320}$ The Special Court Of Sierra Leone saw the crime of enslavement listed as a crime in Article 2 (c) of its statute. $^{321}$

\section{B The Crime of Enslavement under International Criminal Law}

Article 7 (2) ( c ) of the Rome Statute defines enslavement as "the exercise of any or all of the powers attaching to the right of ownership over a person and includes the exercise of such power in the course of trafficking in persons, in particular women and children." ${ }^{, 22}$ In the ICTY case of Prosecutor $v$ Kunarac the Trial Chamber held that enslavement also includes forced labour, where it stated that "Further indications of enslavement includes exploitation; the exaction of forced or compulsory labour or service, often without remuneration" 323

\section{Is the Crime of Enslavement Committed in Burma?}

At Nuremberg the evidence before the Tribunal was overwhelming and hence the Prosecution could prove that the crime of slave labour was committed. ${ }^{324}$ In the cases post Nuremberg the crime of slave labour has also been held to have been committed although the cases post Nuremberg did not resemble the extreme circumstances that the prisoners of war and civilians deported from occupied territories were subjected to in Germany during World War II. ${ }^{325}$

\footnotetext{
${ }^{320}$ See ICTY Statute above n 4, art 5( c), ICTR Statute above n 5, art 3 (c), Rome Statute, above $\mathrm{n} 34$, art 7 (1) ( c)

${ }^{321}$ See Article 2 ( c ) Special Court Of Sierra Leone which states enslavement is a crime against humanity

${ }^{322}$ See Rome Statute above n 34, art 7 (2) (c)

${ }^{323}$ See Prosecutor v Kunarac (Judgment) (22 February 2001) (IT-96-23-T \& IT-96-23/1-T) (Trial Chamber,ICTY) Para 542

${ }^{324}$ See United Nations War Crimes Commission above n 73,27

${ }^{325}$ For instance in Burma villagers are forced to work as slave labours, but the situation in Burma is not as extreme as the situation that existed in Nazi Germany. See HRC Resolution 10/27 above $n$ 3 , para 111
} 
In the ICTY case of Prosecutor $v$ Kunarac the accused appealed against the decision of the Trials Chamber convicting him of the crime of enslavement. ${ }^{326}$ His appeal was based on four grounds. ${ }^{327}$ On the first ground of appeal the appellant stated that for a person to be guilty of the crime of enslavement the accused must have treated the victim "as its own ownership"328 and the appellant stated that the Prosecution had failed to prove that in relation to the victim the accused had treated the victim "as it's own ownership." 329 In dealing with this point the Appeals Chamber stated as follows: ${ }^{330}$

The Appeals Chamber will however observe that the law does not know of a "right of ownership over a person" Article 1 (1) of the 1926 Slavery Convention speaks more guardedly "of person over whom any or all the powers attaching to the right of ownership are exercised." That language is to be preferred.

After a survey of various sources, the Trial Chamber concluded "that at the time relevant to the indictment, enslavement as a crime against humanity in customary international law consisted of the exercise of any or all of the powers attaching to the right of ownership over a person".

The Appeals Chamber accepts the Chief thesis of the Trial Chamber that the traditional concept of slavery, as defined in the 1926 Slavery Convention and often referred to as "chattel slavery", has evolved to encompass various contemporary forms of slavery which are also based on the exercise of any or all of the powers attaching to the right of ownership. In the case of these various contemporary forms of slavery, the victim is not subject to the exercise of the more extreme rights of ownership associated with "chattel slavery" but in all cases, as a result of the exercise of any or all of the powers attaching to the right of ownership, there is some destruction of the juridical personality; the destruction is greater in the case of "chattel slavery" but the difference is one of degree. The Appeals Chamber considers that, at the time relevant to the alleged crimes, these contemporary forms of slavery formed part of enslavement as a crime against humanity under customary international law.

${ }^{326}$ See Prosecutor v Kunarac (Judgment) (22 February 2001) (IT-96-23-A) (Appeals Chamber, ICTY)

${ }^{327}$ Ibid

${ }^{328}$ Prosecutor v Kunarac above n 326, para 107

${ }^{329}$ Ibid

${ }^{330}$ Prosecutor v Kunarac above n 326, Paras 118,116,117 
Based on this reasoning by the Appeals Chamber it is clear that the term "any or all of the powers attaching to the right of ownership" 331 is not to be construed within the context of "chattel slavery." 332 The test that should be used to determine whether the perpetrator could be guilty of the crime of slavery is that firstly the perpetrator must have exercised on the victim "any or all of the powers

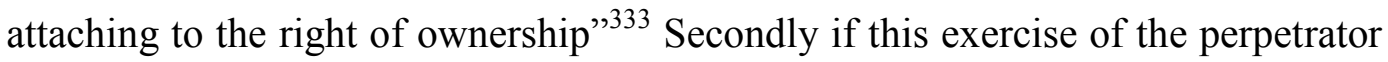
over the victim had resulted in the "destruction of the juridical personality" the victim then this would tantamount to a "contemporary form of slavery.",335

Applying this principle of law to the situation in Burma, it is arguable that when the Junta in Burma conscripts the villagers for work at various project sites without any remuneration ${ }^{336}$ the Junta is exercising "any or all of the powers attaching to the right of ownership" ${ }^{337}$ over the Burmese villagers. Further this exercise of the Junta over the Burmese villagers has resulted in the "destruction of the Juridical personality" ${ }^{1338}$ of the villagers. ${ }^{339}$ This is because the Junta by ordering and forcing the Burmese villagers to work in various sites without remuneration has failed to recognize the rights of these Burmese villagers as persons before the law. ${ }^{340}$

The Appeals chamber further stated that whether a person is enslaved will depend on a number of factors such as: ${ }^{341}$

Control of someone's movement, control of physical environment, psychological control, measures taken to prevent or deter escape, force, threat of force or coercion, duration, assertion of exclusivity, subjection to cruel treatment and abuse, control of sexuality and forced labour.

\footnotetext{
${ }^{331}$ Prosecutor v Kunarac above n 326,para 118

${ }^{332}$ See prosecutor v Kunarac above n 326, Para 117

${ }^{333}$ Ibid

${ }^{334}$ Prosecutor v Kunarac above n 326, para 117

${ }^{335}$ Ibid

${ }^{336}$ See HRC Resolution 5/1 above n 261, Para 58, Para 60

${ }^{337}$ Prosecutor v Kunarac above n 326,para 117

${ }^{338}$ Ibid.Juridicial personality is defined as the right to be recognized as a person before the law and where the person has the capacity to exercise rights. For this definition of juridicial personality see Carem Tiburcio The Human Rights of Aliens under International and Comparative Law (Kluwer Law International,The Hague, The Netherlands, 2001)113

${ }^{339}$ These Burmese villagers are forced to work without any remuneration.

${ }^{340}$ See HRC Resolution 5/1, above n 261, para 58,para 60

${ }^{341}$ Prosecutorv Kunarac above n 326 Para 119
} 
Applying this principle of law to the situation in Burma, when villagers are conscripted in Burma they are forced to work and they are not allowed to leave their area of work ${ }^{342}$ as the soldiers of the Junta who are armed with guns guard these villagers as they are doing the forced labour works. ${ }^{343}$ This would mean that the villagers know that they cannot escape and they have to perform the work designated to them. As such there is control over their physical environment and psychological control is also established.

Further the crime of enslavement would be deemed to be taking place in Burma if it is proved that forced labour is occurring in Burma. ${ }^{344}$ In 2009 the practice of forced labour is still prevalent in Burma as evidenced by the statement made by the United Nations in 2009 where United Nations had urged the government in Burma to activate its efforts to eliminate forced labour. ${ }^{345}$ In 2010 in the report by the Special Rapporteur to Burma it was stated that forced labour was used in the country ${ }^{346}$ and the practise of forced labour was rampant in the areas where corporations in Burma are involved in the extractive industries. ${ }^{347}$ The statements by the United Nations provide concrete evidence that forced labour is prevalent in Burma today.

The second ground of appeal related to the issue of consent. ${ }^{348}$ On this ground of appeal the appellant Kunarac argued that for a crime of enslavement to be established, there must be a "constant and clear lack of consent"349 by the victim throughout the period of detention. ${ }^{350}$ The appellant argued that the victims in their testimony had stated that they were able to move inside and outside the apartment and as such they could have escaped from the place in which they were detained if they wanted to do so. ${ }^{351}$ On this ground the Appeals chamber had stated that the Prosecutor does not have to prove lack of consent as lack of

\footnotetext{
${ }^{342}$ See Earthrights International “Denial The Brutal Irony of Unacol’s Human Rights Investigation" 91

343 Ibid

${ }^{344}$ See the decision of the Trial Chamber in Prosecutor $v$ Kunarac above n 323, para 542

${ }^{345}$ See Situation Of Human Rights In Myanmar GA Res 63/245,A/Res/63/245 (2009)

${ }^{346}$ See Summary of Report on HRC Resolution 10/27 above $n 3$

${ }^{347}$ Report on HRC Resolution 10/27 above n3 para 112

${ }^{348}$ Prosecutor v Kunarac above n 326, para 108

${ }^{349}$ Ibid

${ }^{350} \mathrm{Ibid}$

${ }^{351} \mathrm{Ibid}$
} 
consent is not one of the elements of the crime, as "enslavement flows from claimed rights of ownership." 352 The Appeals Chamber held that consent is relevant only in terms of evidence and the Chamber further stated that in situations where as in this case it was impossible for the victims to give consent as such it can be presumed that there was no consent. ${ }^{353}$ Applying this principle of law to the situation in Burma, it is arguable that it would be impossible for any of the villagers in Burma to consent to forced labour as the villagers are conscripted and forced to leave their villages, families and their livelihood and are forced to work without any remuneration at certain project sites. ${ }^{354}$ It is impossible for the villagers to give their consent in these situations that is imposed upon them therefore it can be presumed that there is no consent by the villagers in Burma.

As the third ground of Appeal the Appellant had raised the issue of duration of time stating that for the crime of enslavement to be established the victims should have been "enslaved for an indefinite or a prolonged period of time." The Appeals Chamber held that the span of time for which an individual is enslaved does not constitute an element of the crime of enslavement and the issue of span of time will be dependent on the circumstances of each case. ${ }^{356}$ In Burma many of these villagers are conscripted as forced labour for varying periods of time. ${ }^{357}$ However the duration of time is not one of the elements of the crime. ${ }^{358}$ As such even if the villagers in Burma are forced to work for short periods of time this cannot be used as a legal point to deduce that the Junta may not be liable for the crime of slave labour. ${ }^{359}$

Where the mental element is concerned the appellants stated that the mens rea that is required is to detain the victim for a long period of time to use them for sexual acts, ${ }^{360}$ however the Appeals Chamber stated that the mens rea consisted

\footnotetext{
352 Prosecutor $v$ Kunarac above n 326, Para 120

353 Ibid

${ }^{354}$ See Earthrights International above n 341, 91. Also See HRC Resolution above n 3, para 112

${ }^{355}$ Prosecutor $v$ Kunarac above n 326,Para 109

${ }^{356}$ Prosecutor v Kunarac above n 326, Para 121

${ }^{357}$ See Earthrights International The Brutal Irony of Unocal's Human Rights Investigation, above n 341,88

${ }^{358}$ Prosecutor $v$ Kunarac above n 326, para 121

359 Ibid

${ }^{360}$ Prosecutor $v$ Kunarac above n 326 para 110
} 
of "intentional exercise of a power attaching to the right of ownership." "361 In Burma it is arguable that the Junta army that conscripts villagers are indeed fulfilling the mens rea for slave labour as they possess the intention and exercises this intention by attaching their "rights of ownership" over the villagers in Burma.

The Appeals Chamber had also cited the case of Oswald Pohl which was also cited by the Trial Chamber in the case of Kunarac. In the case of Oswald Pohl it was held that:- ${ }^{362}$

Slavery may exist even without torture. Slaves may be well fed, well clothed, and comfortably housed, but they are still slaves if without lawful process they are deprived of their freedom by forceful restraint. We might eliminate all proof of illtreatment, overlook the starvation, beatings, and other barbarous acts, but the admitted fact of slavery-compulsory uncompensated labour-would still remain. There is no such thing as benevolent slavery. Involuntary servitude, even if tempered by humane treatment is still slavery.

In Burma labour that is uncompensated is exercised rampantly as discussed above. From the above analysis it can be concluded that the crime of enslavement is being committed in Burma.

\section{Is the Crime Against Humanity of Enslavement Being Committed in Burma?}

From the discussion above it is clear that the crime of enslavement is taking place in Burma however for enslavement to be regarded as a crime against humanity the crime of enslavement has to be "committed as part of a widespread or systematic attack directed against any civilian population with knowledge of the attack.",363

In regards to the element of attack, the Appeals Chamber in Kunarac held that where the Crime Against Humanity is concerned the term attack will include

\footnotetext{
${ }^{361}$ Prosecutor $v$ Kunarac above n 326 para 122

${ }^{362}$ Prosecutor $v$ Kunarac above n 326, para 123

${ }^{363}$ See Rome Statute above n 34, art 7 (1) ( c )
} 
"any mistreatment of the civilian population" 364 In Burma it is arguable that there is an attack as the civilian population are mistreated as the army forces people to leave their villages and these people are forced to work on various locations such as at construction sites, to clear lands, to build helipads to build bridges, to work along pipelines and they are not remunerated for any of the work that is done. ${ }^{365}$

In the case of Kunarac the Appeals Chamber agreed with the decision of the Trials Chamber which held that the requirements of "widespread" or "systematic" is "disjunctive" and not "cumulative." "366 As such even if one of it is satisfied this would be sufficient. ${ }^{367}$ The Appeals Chamber agreed with the Trial Chambers that the phrase "widespread" 368 refers to the scale of the attack that is huge and the amount of the victims are many and the term "systematic"369 refers to "the organized nature of the acts of violence and the improbability of their random occurrence." 370 The Trial Chamber in Kunarac also held that the population that is the object of the attack has to be identified so that it can be ascertained whether the attack on the population is "widespread" or "systematic." 371 In Burma forced labour is conscripted from the villagers on a large scale and are not isolated incidents rather the forced labour used in Burma is widespread throughout the land. ${ }^{372}$ Forced labour is prevalent throughout the country as whenever there are developmental projects that take place in Burma for instance in the extraction of oil and gas in Burma the TNCs and the Junta sign joint venture agreements for the extraction of oil and gas. ${ }^{373}$ These kinds of huge projects will require that the lands surrounding these areas needs to be cleared as pipelines has to be built hence forced labour is used widely to ensure that these works are done. ${ }^{374}$ Forced labour in Burma is also done in a systematic manner as the use of force labour is

\footnotetext{
${ }^{364}$ Prosecutor v Kunarac above n 326, Para 86

365 SeeTyler R.Gianni Destructive Engagement:A Decade Of Foreign Investment In Burma in an Issue paper of Earthrights International's Burma Project,(1999)12Also See Report on HRC Resolution above n 3 , Para 112

${ }^{366}$ Prosecutor $v$ Kunarac above n 326 Para 97

367 Ibid

${ }^{368}$ Prosecutor v Kunarac above n 326, para 95

369 Ibid

${ }^{370}$ Prosecutor $v$ Kunarac above n 326 Para 94

${ }^{371}$ Prosecutor $v$ Kunarac above n 326 Para 95

${ }^{372}$ See Summary of Report on HRC Resolution 10/27 above n 3,2

${ }^{373}$ See Report on HRC resolution 10/27 above n3, Para 111

${ }^{374}$ See Report on HRC resolution 10/27 above n 3, Para 112
} 
regulated and overseen by the military on the instruction of the Junta. ${ }^{375}$ Further there are at least 50 labour camps in Burma. ${ }^{376}$ As such if the population of Burma is ascertained it is clear that forced labour that happens in Burma is not only "widespread" but also "systematic" 377 As such the second element of the crime of enslavement in Burma is fulfilled.

In relation to the issue of plan or policy, the Appeals Chamber concurred with the Trials Chamber in Kunarac that the attack need not be supported by a "plan or policy" 378 as this is not an element of the crime but it could be relevant in terms of evidence. ${ }^{379}$ Further the Appeals Chamber stated that the Trial Chamber had correctly identified that in relation to the acts of the accused and the attack two elements has to be satisfied that is: ${ }^{380}$

the commission of an act which by its nature or consequences is objectively part of the attack; coupled with

Knowledge on the part of the accused that there is an attack on the civilian population and that his act is part thereof.

This element is satisfied as in Burma when the Junta army forces the villagers to commit forced labour these acts if looked at from an objective point of view naturally forms a part of the attack as forced labour is committed in various villages in Burma. ${ }^{381}$ Further when the army forces the people to work as forced labourers the army possesses the knowledge that forced labour is used widely in Burma and the act they are committing are not simply isolated incidents but are a part of a widespread attack as forced labour is occurring all over Burma. ${ }^{382}$ Based on the above analysis it can be ascertained that the Crime against Humanity of Enslavement is occurring in the $21^{\text {st }}$ century in Burma.

\footnotetext{
375 Ibid

${ }^{376}$ Prosecutor v Kunarac above n 326, para 95. Also See Report on HRC resolution 10/27 above $\mathrm{n}$ 3, Para 20

${ }^{377}$ Ibid. Also see HRC Resolution 5/1 above n 261, para 58

${ }^{378}$ Prosecutor $v$ Kunarac above n 326, para 98

${ }^{379}$ Prosecutor V Kunarac above n 326 Para 98

${ }^{380}$ Prosecutor $v$ Kunarac above n 326 Para 99

${ }^{381}$ See Report on HRC resolution 10/27 above n3, Para 111, Para 112

382 Ibid
} 
In ascertaining the role played by TNCs in the commission of forced labour in Burma the projects known as the Yadana which involves the collaboration of the TNCs and the Junta in Burma ${ }^{383}$ will be used to illustrate the role played by the TNCs in Burma for the Crime Against Humanity of Slave labour / Force Labour .

The companies involved in the Yadana Project are Total from France,Unacol from US, PTTETT from Thailand and the Junta controlled MOGE. ${ }^{384}$ However after the case of Doe v Unocal, Unocal sold its shares in the Yadana project to another American company known as Chevron who continues playing the role held by Unocal in the Yadana project. ${ }^{385}$ The Thai counterpart in the Yadana project is held by PTTETT $^{386}$ a Thai company which "holds a $25.5 \%$ stake in the consortium" 387 and MOGE the Junta regime controlled company has a stake of $15 \%$ in the consortium. ${ }^{388}$

\section{F The Role Played by Translational Corporations and the Officials of Transnational Corporations in the Commission of Crime Against Humanity of Enslavement in Burma.}

TNCs along the Yadana pipelines such as Chevron, Total and PTTETT had alerted the Junta army that they needed security for the pipeline to ensure that extraction works that the TNCs were involved in would run smoothly. ${ }^{389}$ As such

\footnotetext{
${ }^{383}$ See HRC Resolution 10/27 above n 3, para 112

${ }^{384}$ Earthrights International-Chevron and The Yadana Pipelinewww.earthrights.org/campaignfeature/Yadana pipeline html (accessed 14 March 2009)

${ }^{385}$ Earthrights International The Human Cost Of Energy: Chevron's continuing role in financing oppression and profiting from human rights abuses in Military rules Burma (Myanmar):Report of Chevron's role in Burma (prepared for the promotion and protection of human rights in Burma,2008)20

${ }^{386}$ Ibid

387 Ibid

388 Ibid

${ }^{389}$ See Earthrights International Earth Rights Abuses by corporations in Burma and collective summary and recommendations : Report Of Abuses by Corporations in Burma (prepared for submission to the special representative on the issue of Human Rights and Transnational
} 
the TNCs such as Total, Chevron and PTTETT had given the Burmese Army the responsibility of hiring individuals to provide security for the pipelines although the TNCs and the officers of TNCs had full knowledge that the Junta and the army of the Junta were well known for committing various human rights abuses and they were also aware of the fact that forced labour was widely used by the Junta army in Burma. ${ }^{390}$ The TNCs request for security along the pipelines was adhered to by the Junta army who provided security along the pipelines which resulted in dire consequences as the people in the villages in Burma who were subjected to various human rights abuses such as forced labour and Portering. ${ }^{391}$ The Junta army that provided security along the pipelines almost immediately conscripted forced labour from the people in the villages. ${ }^{392}$ Those who were conscripted as forced labour were forced to do work along the pipelines such as clearing the lands along the pipelines and they were also forced to build military barracks. ${ }^{393}$ As such forced labour was used extensively along the pipelines. ${ }^{394}$ Forced portering resulted as the army that were required to give security along the pipelines forced the villagers to carry ammunition and various other materials that the army needed while the army was securing the pipelines for the TNCs.${ }^{395}$ Despite the knowledge of the human rights abuses that was bound to occur in relation to the Yadana projects the TNCs proceeded with the project working together with the Junta army. ${ }^{396}$ The Junta army and the TNCs were totally dependent on each other to ensure that the project worked smoothly and the TNCs paid monies to the Junta army to ensure that work along the pipelines were done and that the pipelines were secure. ${ }^{397}$ At present the same events is occurring where the TNCs are requesting the Junta for security along the pipelines

Corporations and other business enterprises, 2005)Also See Report on HRC resolution 10/27 above n3, Para 112

${ }^{390}$ The pipeline To Riches http://www.bangkokpost.com (last accessed 11 April 2010)

${ }^{391}$ Ibid Also See Report on HRC resolution 10/27 above n3, Para 112

${ }^{392}$ Ibid

${ }^{393}$ Ibid

${ }^{394}$ Ibid

${ }^{395}$ Ibid

${ }^{396}$ Ibid

${ }^{397}$ See HRC Resolution 5/1 above n 261, Para 60, Para 75. the Junta uses forced labour on various project sites and the Junta has earned billion of dollars from the Yadana project since the year 2000. 
and this is agreed to by the Junta. ${ }^{398}$ Consequently various human rights abuses such as forced labour continue to occur in Burma. ${ }^{399}$ In 2010 the Special Rapporteur to Burma in his report to the Human Rights Council at the United Nations had stated that: ${ }^{400}$

It has been reported that extraction activities have directly resulted in an increase in human rights and environmental abuses committed by the military against the people living along the PTT Exploration and Production Public Company Limited's Yadana and Yetagun gas pipeline projects in the Tennasserim region of Myanmar. Reports highlight the close relationship between the extraction companies and the armed forces. The companies rely on the Myanmar military to provide security for their projects.

\section{G Complicity; A Growing Phenomenon in International Criminal Law}

The concept of complicity was recognised as early as the Nuremberg trials. ${ }^{401}$ Principle VII in Nuremberg Charter states that "Complicity in the commission of a crime against peace, a war crime ,or crime against humanity as set forth in principle VI is a crime under International law."402 The United States Military Tribunal had relied on the theory of complicity and found some of the officials of the firms of IG Farben, Krupp and Flick guilty of Crime against Humanity of slave labour and for the War crime of pillage, plunder and spoliation. ${ }^{403}$ The Tribunal held that these officials of the firms were guilty for these crimes by aiding and abetting the Third Reich who were the principal perpetrators of these crimes. ${ }^{404}$ Subsequent to the Nuremberg Trials of the Industrialist, the ICTY cases have also held that individuals are liable for War Crimes, Crimes against Humanity and Genocide by using the theory of complicity

\footnotetext{
${ }^{398}$ See Report on HRC Resolution 10/27 above n 3, Para 112

${ }^{399}$ See Summary of report HRC Resolution 10/27 above n 3.

${ }^{400}$ See HRC Resolution 10/27 above n 3, para 112

${ }^{401}$ See Principle VII of the Principles of Nuremberg Tribunal, 1950

${ }^{402}$ Principles of International Law Recognized In the Charter of the Nuremberg Tribunal and in the Judgment of the Tribunal (1950) Yearbook Of The International Law Commission para 97

${ }^{403}$ See United States Of America v Carl Krauch And Twenty Two Others above n 37, 1137. The main perpetrators of these crimes were the Third Reich and some of the officials of Farben, Krupp and Flick were held to be complicit in these crimes.

${ }^{404}$ See United States Of America V Carl Krauch And Twenty Two Others above n 37,1140 for details of the complicity of industrialists
} 
and aiding and abetting to link individuals and consequently finding them guilty for war crimes, crimes against humanity and Genocide. ${ }^{405}$

\section{H Some Definitions of Complicity.}

The complex nature of complicity especially in the context of International Criminal Law makes it difficult to give it a single definition that would explain the concept of complicity as what amounts to complicity would depend on the particular facts and circumstances of each situation and case. ${ }^{406}$ John Ruggie refers to Complicity as the "indirect involvement by companies in human rights abuses-where the actual harm is committed by another party, including governments and non-state actors. ${ }^{, 407}$ Andrew Clapham in the following statement explains why it is difficult to define complicity: ${ }^{408}$

Complicity means different things in different contexts and allegations of complicity tell us much about the concerns of the person making the allegations. It would be foolish to suggest there is an independent meaning for complicity in international law that we can simply strictly apply to determine whether we can label corporate behaviour complicit in human rights abuses.

Complicity by Corporations can be divided into three main categories that is direct complicity, indirect complicity and silent complicity. ${ }^{409}$

\section{$1 \quad$ Direct corporate complicity}

Direct Corporate Complicity ${ }^{410}$ requires that there has to be participation that is intentional however there need not be any intention to cause harm but only ${ }^{411}$ "knowledge of foreseeable harmful effects" "412 Where a Corporation

\footnotetext{
${ }^{405}$ For instance in the case ICTY case of Prosector v Dr Milomir $v$ Stakic the Defendant was accused of complicity in genocide but was acquitted of this count of crime by the ICTY.

${ }^{406}$ See Andrew Clapham “On Complicity” 2002 Le Droit Penal A L'epreuve de L'internationalisation 241,275

${ }^{407}$ John Ruggie 2009 Human Rights And Transnational Corporations and other Business Enterprises A/HRC/8/5 (2008) para 73

${ }^{408}$ Andrew Clapham above n 406,275

409 Andrew Clapham And Scott Jerbi "Categories Of Corporate Complicity in Human Rights Abuses” (2001) 24 Hastings Int'I \& Comp. L.Rev 339,340

${ }^{410}$ Ibid

${ }^{411}$ Ibid

${ }^{412}$ Ibid
} 
renders its assistance by participating in a human rights abuse and this leads to the commission of the human rights abuses, the act of the corporation amounts to direct complicity. ${ }^{413}$ It is unnecessary for the corporations to wish that human rights abuses occur, but the corporation must know the likely consequences of the assistance rendered. ${ }^{414}$ Examples of direct complicity are the actions taken by the German and Japanese Corporations in World War II. ${ }^{415}$ Further a corporation with knowledge who assists a state in contravening the principles of customary international law that is found in the Universal Declaration of Human Rights ${ }^{416}$ can be said to be committing direct corporate complicity. ${ }^{417}$ For instance a corporation that had either promoted or alternatively assisted in forced relocation of the people in situations that will tantamount to a breach of international human rights can be said to be ${ }^{418}$ complicit in a direct manner in the violation. ${ }^{419}$

\section{$2 \quad$ Indirect corporate complicity}

Under the limb of indirect corporate complicity, corporations are not the direct perpetrator of the crimes or human rights abuse in question but the corporation is the party that benefits from the human rights abuses committed by the host government. ${ }^{420}$ Under this limb corporations could be found liable for International Crimes if it can be proven ${ }^{421}$ that "close collaboration in a business venture provides substantial support for a government's violation of human rights in furtherance of the business venture." ${ }^{, 422}$

\section{$3 \quad$ Silent complicity}

Corporations that continue to carry on business in a country where there is "repressive political history" 423 could be liable under the category of Silent

\footnotetext{
${ }^{413}$ See Anita Ramasastry above n 39,102

${ }^{414}$ Anita Ramasastry above n 39, 102

${ }^{415}$ Ibid

${ }^{416}$ Ibid

${ }^{417}$ Ibid

${ }^{418}$ Ibid

${ }^{419} \mathrm{Ibid}$

${ }^{420}$ Anita Ramasastry above n 39,102

${ }^{421}$ Ibid

${ }^{422}$ Ibid

${ }^{423}$ Ibid
} 
Complicity. ${ }^{424}$ For instance Corporations that continued to do business with the South African Government that advocated apartheid could be liable for silent complicity. ${ }^{425}$

$4 \quad$ The three elements of complicity in international crimes.

There are three elements in Complicity especially in the sphere of International Criminal Law, the first is that an accomplice can be tried for complicity even where the principal offender cannot be found or where the guilt of the principal cannot be proved. ${ }^{426}$ An analogy that can be illustrated here is the situation involving the TNCs In Burma, where if in the near future due to some reasons if the principal perpetrators of the crimes that is the Junta cannot be prosecuted or guilt cannot be imputed on the Junta nevertheless the TNCs could still be tried for complicity for the crimes committed.

The second element is that the accomplice need not desire that the principal offence is committed and in regards to this issue the Trial Chambers had stated that so long as the accomplice at the moment he is committing the offence knows he was assisting the principal offence he can be convicted of being complicit. ${ }^{427}$ Therefore if an accomplice had knowledge of the criminal offence of another and he aids and abets he can be convicted of complicity even if he later regrets it. ${ }^{428}$ For instance where the TNCs in Burma are concerned, when the TNCs signs joint ventures with the Junta they knew of the crimes such as plunder and slave labour that is occurring in Burma, ${ }^{429}$ in such a situation the TNCs could be complicit in the aforesaid crimes.

The third element concerns the issue as to what sort of action would suffice to be termed complicity and this would include aid and abet, counsel and

\footnotetext{
${ }^{424}$ Ibid

${ }^{425}$ Ibid

${ }^{426}$ See Prosecutor v Akayesu, (Judgment) (2 September 1998) (ICTR-96-4-T)(Trial Chamber,ICTY) Para 531

${ }^{427}$ Prosecutor v Akayesu, above n 426 Para 538

${ }^{428}$ Ibid

${ }^{429}$ Crimes such as plunder and slave labour is occurring in Burma .SeeHRC Resolution 5/1 above n 261, para 33, para 64 .
} 
procure. $^{430}$ Therefore the TNCs in Burma could be complicit with the Junta for various International Crimes if the TNCs aid and abet the Junta.

\section{How Was Complicity Defined in Nuremberg?}

Complicity was defined in a very wide ambit in Nuremberg. ${ }^{431}$ In case of United States of America v Oswald Pohl And Seventeen Others it was stated that a huge and complex operation that involved the killing of millions of Jews and the appropriation of their properties could not be executed by one man. ${ }^{432}$ To illustrate this point the Tribunal gave an example of four persons who were involved in a bank robbery ${ }^{433}$ one sketched the plan for the robbery, the second drove to the bank to commit the robbery, the third pulls the trigger and the fourth collects the loot from the robbery. ${ }^{434}$ The Tribunal stated in such a circumstances the scope of the whole plan has to be ascertained and when this is done, then within the whole scope of the plan the acts of one of them becomes the acts of others as well ${ }^{435}$ This means that all four of them were complicit as all of them knew of the crime and each did their part to execute the crime, therefore in such a situation they are all guilty of the crime. ${ }^{436}$ The judgments of the Tribunal indicates that those who were "accessories only after the fact" were also found to be criminally liable. ${ }^{437}$ The Tribunal illustrated this point by stating that just because Pohl did not remove gold teethes from the dead persons did not mean he was innocent of the crime. ${ }^{438}$ Although his part was to keep the loot but since he had knowledge of the purposes of the crime that was not lawful that made him a particeps criminis in the situation. ${ }^{439}$ In the case of United States of America v Josef Alstoetter and Fifteen Others (commonly known as the Ministries case) the Tribunal further enlightened on the concept of complicity which was relied on at Nuremberg when

\footnotetext{
${ }^{430}$ Prosecutor $v$ Akayesu above n 426, Para 535

${ }^{431}$ See United Nations War Crimes Commission, Digest Of Laws And Cases (Volume XV) 49

${ }^{432}$ United Nations War Crimes Commission 431,52

${ }^{433}$ United Nations War Crimes Commission above n 431, 53

${ }^{434}$ Ibid

${ }^{435} \mathrm{Ibid}$

${ }^{436} \mathrm{Ibid}$

${ }^{437}$ Ibid

${ }^{438}$ Ibid

${ }^{439}$ Ibid
} 
it stated that if individual A persuades another to kill, and individual B furnishes the weapon, and individual $\mathrm{C}$ pulls the trigger, in such a situation all three of them are principles and accessories of the crime. ${ }^{440}$ In Nuremberg those who had knowledge of the offence was held to be complicit. ${ }^{441}$ Further those who were sufficiently "connected with" the crime was also guilty of the said crime by way of complicity. ${ }^{442}$

\section{J An analysis of Complicity in the Nuremberg Cases in Relation to the Crime of Enslavement}

In the case of Oswald Pohl it was stated that Pohl was an officer of the SS who reported directly to Himmler and Oswald Pohl was given the designation of converting former detention places into camps where there was free labour and he's designation and job was to ensure that this policy was put into practise for the Third Reich. ${ }^{443}$ As such everything to do with concentration camp administration was handled by him. ${ }^{444}$ By 1944,165 labour camps were supervised by his main office. ${ }^{445}$ At some occasions he took the liberty to inspect concentration camps in person such as the camps in Auschwitz and Dachau. ${ }^{446}$ Further he knew all the details that happened in the concentration camps that is how many died, how many were unfit to work, that hundreds and thousands of men and women were sent to the concentration camps and were forced to work without any remuneration. ${ }^{447}$ The Tribunal stated that in the case of Oswald Pohl in the situation involving slave labour "it was more than a mere consenting part. It was active participation" 448 The Tribunal stated that he was a "slave driver"449 and

\footnotetext{
${ }^{440}$ Ibid

${ }^{441}$ United Nations War Crimes Commission above n 431,54

${ }^{442}$ Ibid

${ }^{443}$ United States Of America v Oswald Pohl And Seventeen Others, (1949) V, Trials Of War Criminal Before The Nuremberg Military Tribunal 980,981

${ }^{444}$ Ibid

${ }^{445}$ United States Of America v Oswald Pohl And Seventeen Others, above n 443,983

${ }^{446}$ Ibid

${ }^{447}$ United States Of America v Oswald Pohl And Seventeen Others above n 443,984

${ }^{448}$ Ibid

${ }^{449}$ Ibid
} 
found him guilty of war crimes and crimes against humanity such as slave labour. $^{450}$

Based on the decision of the Tribunal in the Oswald Pohl case it can be said that an individual would be found guilty for being complicit in crimes against humanity such as slave labour when firstly he takes an active part in the crime, secondly when he has knowledge about what is happening in the concentration camps such as the deaths that occur, the condition of the workers in the camp, that the workers are not paid any remuneration and thirdly when he has authority to give orders in relation to the slave labours in the camp. ${ }^{451}$

In the Oswald Pohl case the threshold used to find him complicit was high as he was as SS officer and many of the concentration camps were directly supervised by him. ${ }^{452}$ As such in the case of Oswald it was very clear that he was complicit in the crime of slave labour. ${ }^{453}$ However in Nuremberg the complicity for slave labour was not limited to only officers of the SS but even corporate officials were held to be complicit in the crime of slave labour. ${ }^{454}$

In the three industrialists cases of IG Farben, Krupp and Flick the Tribunal held that some of the officials of IG Farben, Krupp and Flick were complicit in the crime of slave labour because the officials of these firms had firstly used slave labour, ${ }^{455}$ secondly in the case of IG Farben, the officials of IG Farben had "requested, embraced and followed" the slave labour programme, ${ }^{456}$ thirdly they had knowledge about the conditions the slave labourers were in, ${ }^{457}$ fourthly they had used the slave labourers and it brought these officials profits and their firms benefitted and their enterprises expanded economically. ${ }^{458}$ Fifth they did not object to the slave labour being used. ${ }^{459}$ In short although these officials did not construct the slave labour programme nor supervised the slave labour programme

\footnotetext{
450 Ibid

${ }^{451}$ United States Of America v Oswald Pohl And Seventeen Others above n 443, 983,984

452 United States Of America v Oswald Pohl And Seventeen Others above n 443,980,981

${ }^{453}$ United States Of America v Oswald Pohl And Seventeen Others above n 443, 984

${ }^{454}$ See United States Of America v Carl Krauch And Twenty Two Others above n 37, 1196

${ }^{455}$ United States Of America v Carl Krauch And Twenty Two Others above n 37,1172

456 Ibid

${ }^{457}$ United States War Crimes commission above n 70, 93

${ }^{458}$ See United States Of America v Alfried Krupp And Eleven Others above n 168, 1411

${ }^{459}$ See United States Of America v Alfried Krupp And Eleven Others above n 168, 1423
} 
yet all these officials had engaged in "positive conduct" in relation to the furtherance of this slave labour programme and had enjoyed the benefits of slave labour. ${ }^{460}$ The verdict of the tribunal in Nuremberg may have been different had the officials of IG Farben, Krupp and Flick refused to cooperate in the slave labour programmes by not taking any positive actions in furtherance of the slave labour programme.

\section{K An Analysis of the Complicity of the Officials of Transnational}

\section{Corporations in Burma For The Crime Of Enslavement.}

The officials of TNCs are not the perpetrators of the slave labour. ${ }^{461}$ However if the officials of TNCs in Burma have taken positive action in the slave labour programme and accepted, followed and went ahead with the slave labour programme perpetrated by the Junta and if they had benefitted from $i^{462}$ they could be found complicit in the crime of slave labour. ${ }^{463}$ The officials of the TNCs in Burma such as Chevron,Total and PTTETT have never objected to the use of slave labour. ${ }^{464}$ Therefore it can be said that to some extent the actions of the officials in TNCs in Burma have encouraged the use of forced labour. ${ }^{465}$ The officials of TNCs such as Chevron, Total and PTTETT can be said to have taken "positive action" in that they had followed, accepted and went ahead with the slave labour programme. ${ }^{466}$ This can be deduced from the actions of the officials of TNCs who rely on the army to provide them with security although they have knowledge that slave labour is rampantly used by the Junta and the army of the Junta. $^{467}$

\footnotetext{
${ }^{460}$ For instance see United States Of America v Alfried Krupp And Eleven Others above n 168, 1411

${ }^{461}$ The Junta uses its army the Tatmadaw to commit forced labour in Burma.See Report on HRC Resolution 10/27 above n 3, Para 112.

${ }^{462}$ See Report on HRC resolution 10/27 above n 3, Para 111, Para112

${ }^{463}$ For instance in the case of Krupp, the Tribunal stated that the Krupp firm benefitted from the use of slave labour, therefore some of the officials were found guilty of this count of crime of slave labour.See United States of America v Alfried Krupp And Eleven Others, above n 168,1411 ${ }^{464}$ Ibid

${ }^{465} \mathrm{Ibid}$

${ }^{466} \mathrm{Ibid}$

${ }^{467}$ See Report on HRC Resolution 5/1, above n 261, para 66,Also See HRC Resolution 10/27 above $\mathrm{n} 3$, para 111 , para 112
} 
In relation to the element of benefit it is clear that the officials of TNCs in Burma are the recipients of benefit flowing from the crime against humanity of slave labour in Burma. ${ }^{468}$ Applying the element of benefit to ascertain the liability of the officials of TNCs in Burma, it is clear that the TNCs do obtain the benefit when the crime of forced labour is committed in Burma. ${ }^{469}$ This deduction can be made because whenever there are joint ventures that are entered into by the Junta and the TNCs, forced labour is employed extensively by the Junta regime to ensure that the business ventures that has been executed between the Junta and TNCs will run smoothly and achieve success and this invariably benefits the TNCs. ${ }^{470}$ For instance in the Yadana pipeline, security was needed by the TNCs and the TNCs had asked the Junta for security. ${ }^{471}$ Junta obliged their request to supply the security to guard the pipeline and consequently the members of the Junta army were taken as security to guard the pipeline. ${ }^{472}$ Subsequently the Junta army conscripts the villagers to work as forced labourers along these pipelines. ${ }^{473}$ This invariably brought benefit to the TNCs and the Junta regime as they make the profits from the joint venture and the abuses such as forced labour continue to flourish in Burma. ${ }^{474}$

The defence of necessity was successfully invoked by some of the officials in the Industrialists cases of IG Farben, Krupp and Flick ${ }^{475}$ which has been discussed in the previous chapter. By analogy and based on the decisions of the tribunal at Nuremberg the officials of TNCs even if they invoked the defence of necessity this defence, in the view of this author is not likely to prevail as where the officials of TNCs are concerned they are under absolutely no coercion to undertake business in Burma with the Junta. Their presence in Burma is

\footnotetext{
${ }^{468}$ Ibid

${ }^{469}$ The TNCs benefit greatly in the Joint Venture it does with Burma as the Yadana pipeline is very profitable to the Junta and TNCs . See Also HRC Resolution 10/27 above n 3, para 111, para 112

${ }^{470}$ See report on HRC Resolution 10/27 above n3, Para 111

${ }^{471}$ See Report on HRC Resolution 10/27 above n 3, Para 112

472 Ibid. Also See Earthrights International Denial The Brutal Irony of Unocal's Human Rights Investigation, above $\mathrm{n} 314,78$

${ }^{473}$ See Report on HRC Resolution 10/27 above n 3, Para 112

${ }^{474}$ See Summary of Report HRC Resolution 10/27, above $\mathrm{n}$ 3, where it is stated that forced labour is used throughout Burma.

${ }^{475}$ For instance see United States Of America v Friedrich Flick And Five Others above n 223, 1201
} 
motivated purely by the pursuit of profit. ${ }^{476}$ Further the officials of TNCs will not be able to assert what was asserted in the Flick case that is had they not participated in the forced labour programme they will be in "clear and present danger." ${ }^{477}$ It is clear that the defence of necessity which was employed successfully by some of the officials in the industrialists cases will not have any venue of success in relation to the officials of TNCs in Burma.

\section{Aiding And Abetting; A Form of Complicity under International Criminal Law}

Aiding And Abetting has long been recognised as a method of ascertaining liability under International Criminal Law as aiding and abetting is one form of complicity under International Criminal Law. ${ }^{478}$ In both the Nuremberg trials of the industrialists and in the ICTY cases complicity and aiding and abetting were used under International Criminal Law to link liability for International Crimes to individuals and not to legal persons such as TNCs. ${ }^{479}$ Here the analysis done seeks to determine whether the officials of TNCs in Burma could be liable under International Criminal Law for Crimes Against Humanity of Enslavement in the light of the growing jurisprudence of aiding and abetting found in the Nuremberg cases and the ICTY cases.

\section{An Analysis of the Actus Reus and Mens Rea Requirement of Aiding and Abetting in Relation to the Industrialists Cases at Nuremberg}

In the case of United States of America v Carl Krauch And Twenty Two Others at Nuremberg, the Tribunal in ascertaining the liability of the officials of

\footnotetext{
${ }^{476}$ The TNCs and the Junta earns millions of dollars from the joint ventures. See HRC resolution $10 / 27$ above n 3, para 102

${ }^{477}$ See United States Of America v Friedrich Flick and Five Others Flick above n 223, 1201

${ }^{478}$ See Doug Cassel "Corporate Aiding And Abetting Of Human Rights Violations :Confusion in the Courts" (2008) Northwestern J IHR 304,306

${ }^{479}$ See United States of America v Carl Krauch And Twenty Two Others above n 37, 1153.In the industrialist cases of Farben, Krupp and Flick the corporation was not indicted but the officials of the corporation were indicted for various international crimes. In the case of Akayesu as well individuals were indicted for being complicit by aiding and abetting crimes.
} 
Farben for the crime of pillage had made the following statements in regards to the actus reus and mens rea requirement: ${ }^{480}$

\begin{abstract}
Unless the competent proof establishes beyond reasonable doubt that he knowingly participated in an act of plunder or spoliation because he was either a (a) a principal, or (b) an accessory to the commission of any such crime, or ordered or abetted the same or (c) took a consenting part therein, or (d) was connected with plans and enterprises involving its commission, or (e) was a member of an organization or group connected with the commission of any such crime.
\end{abstract}

According to this definition given by the tribunal an individual would be guilty as an aider or abettor of the crime if the person had the requisite knowledge of the crime that was committed when the person took part in the crime, therefore the mens rea element is knowledge. ${ }^{481}$ The person would fulfil the actus reus element of the crime if the individual had taken part in the crime either as a principal, or becomes an accessory to the crime that is committed by ordering the commission of the crime or abetting the crime. ${ }^{482}$ If the individual has consented to take part in the crime this will also suffice as the actus reus. ${ }^{483}$ The actus reus element is also satisfied if the individual had made connection with plans and enterprises involving the commission and finally the actus reus is also realised if the individual was a part of an organisation as a member that was linked with the commission of the crime. ${ }^{484}$

In the cases of IG Farben, Krupp and Flick the tribunal found some of the officials attached to these firms guilty of the crime of slave labour. ${ }^{485}$ It was apparent to the tribunal that some of the officials of the firms had satisfied the mens rea requirement as these industrialists had knowledge that the slave labour programmes were widely used in their respective corporations although the

\footnotetext{
${ }^{480}$ United States Of America v Carl Krauch and Twenty Two Others above n 37,1137

${ }^{481}$ Ibid

${ }^{482}$ Ibid

${ }^{483} \mathrm{Ibid}$

${ }^{484} \mathrm{Ibid}$

${ }^{485}$ For Instance see United Nations War Crimes Commission above n 73,27
} 
perpetrator of the slave labour programme was the Third Reich. ${ }^{486}$ The actus reus was satisfied by some of the officials in the three firms because as the tribunal noted in the IG Farben case that IG Farben had "embraced, adopted and executed the forced labour policies of the Third Reich" ${ }^{487}$ The words used by the tribunal connotes that some of the officials of Farben had worked together with the Third Reich in the use of slave labourers hence the actus reus element was definitely fulfilled by some of the officials in the firm of Farben. ${ }^{488}$ The officials of the Krupp firm that was also using slave labour extensively were held to be guilty of the crime of slave labour. ${ }^{489}$ The tribunal stated that the Krupp firm not only desired the slave labour programme but the Krupps had also benefitted from it. ${ }^{490}$ The element of knowledge was satisfied as slave labour was used extensively by the officials of the Krupp firm and the officials of the firm knew that a crime was being committed. ${ }^{491}$

\section{N The Actus Reus and Mens Rea Requirement of Aiding and Abetting under International Criminal Law(ICL)}

Article 25 (3) (c) of the Rome Statute lays down the actus reus and mens rea of aiding and abetting by stating that "For the purpose of facilitating the commission of such a crime, aids, abets or otherwise assists in its commission or its attempted commission, including providing the means for its commission." ${ }^{, 492}$ The test for the Actus Reus requirement and the mens rea requirement for aiding and abetting was laid down by the ICTY in the case of Prosecutor $v$ Furundzija where the ICTY stated that: ${ }^{493}$

In sum The Trial Chamber holds that the actus reus of aiding and abetting in international criminal law requires practical assistance, encouragement, or moral support which has a substantial effect on the perpetration of the crime. The mens rea required is the knowledge that these acts assist the commission of the offence. This notion of aiding and abetting is to be distinguished from the notion of common

\footnotetext{
${ }^{486}$ Ibid 26,27

${ }^{487}$ United States Of America v Carl Krauch And Twenty Two Others above n 37, 1172

${ }^{488}$ Ibid

${ }^{489}$ United States Of America v Alfried Krupp And Eleven Others above n 168,1449,1451

${ }^{490}$ United States Of America v Alfried Krupp And Eleven Others above n 168,1423,1411

${ }^{491}$ See United States Of America v Alfried Krupp And Eleven Others above n 168,1423

${ }^{492}$ See Rome Statute, above n 34, art 25 (3 ) (c)

${ }^{493}$ Prosecutor v Furundzija (IT-95-17-T) (Trial Chamber) (Judgment) (10 December 1998)
} 
design, where the actus reus consists of participation in a joint criminal enterprise and the mens rea required is intent to participate.

The area of the mens rea requirement for aiding and abetting liability is interwoven with a list of cases. ${ }^{494}$ There are two lines of cases in relation to the proper requirement of mens rea that is whether the aider and abettor must possess knowledge of the crime or whether the aider and abettor must have the mens rea of purpose that the crime be committed. ${ }^{495}$ This can be referred to as the knowledge test or the purpose test. ${ }^{496}$

In the case of United States of America v Ernst von Weizaecker and Twenty others ${ }^{497}$ one of the accused in this case was Karl Rasche a banker. ${ }^{498}$ The issue in relation to this accused was whether he could be guilty of aiding and abetting the crime against humanity of slave labour. ${ }^{499}$ In this case Rasche worked in the Dresdner bank and evidence was adduced to show that he had loaned huge sums of money to the SS enterprise and the Reich enterprise. ${ }^{500}$ Karl Rasche had secured the loans from the bank mostly on his own initiative and he had knowledge that the purposes of the said loans were utilised by the SS enterprise and the Reich enterprise for maintaining slave labour camps and for resettlement programmes. ${ }^{501}$ The Tribunal asked the question whether it was illegal to make a loan when the individual knew that the loans will be used to finance the Reich and SS enterprises that used slave labour which is a crime under national law and international law. ${ }^{502}$ The Tribunal stated that the act of the accused was not illegal. ${ }^{503}$ The Tribunal further stated that although his acts could be condemned from a moral point of view but his actions was not a violation of international

\footnotetext{
${ }^{494}$ Doug Cassel above n 478, 308

${ }^{495}$ Ibid

${ }^{496}$ Ibid

${ }^{497}$ United States Of America v Ernst von Weizaecker And Twenty Others (1949) XIV Trials Of War Criminals .This case is often referred to as the Ministries case

${ }^{498}$ United States Of America v Ernst von Weizaecker And Twenty Others above n 497,621

${ }^{499}$ Ibid

500 Ibid

501 United States Of America v Ernst Weizaecker And Twenty Others above n 497, 622

${ }^{502}$ Ibid

${ }^{503} \mathrm{Ibid}$
} 
law. ${ }^{504}$ In this case the Tribunal did not use the knowledge test and Karl Rasche was acquitted of the charge of aiding and abetting the Crime against humanity of slave labour. $^{505}$

In the ICTY case of Proseutor v Furundzija the accused a commander had interrogated a woman, a non combatant and had watched as she was raped and sexually assaulted by the soldiers. ${ }^{506}$ The issue was whether the accused could be liable for aiding and abetting the crimes which was committed by the soldier upon the woman pursuant to Additional Protocol II of 1977 for outrages upon personal dignity which included rape. ${ }^{507}$ The Defence argued that the accused was not guilty of the crimes and he was not present when the crimes took place. ${ }^{508}$ The ICTY stated that the "positive intention" of the principal "to commit the crime" need not be shared by the aider and abettor. ${ }^{509}$ If the aider and abettor has the requisite knowledge that his actions will be of assistance to the principal to commit the crime this will be sufficient to convict the accused of aiding and abetting the crime. ${ }^{510}$ In this case the ICTY found that the accused was guilty of aiding and abetting the crimes alleged. ${ }^{511}$

Article 25 (3) (c) of the Rome Statute seems to proposes a purpose test. ${ }^{512}$ The purpose here may not be the primary purpose but rather it refers to only a secondary purpose through which knowledge of the likely consequences can be inferred. ${ }^{513}$ Article 25 (3) (c) must be interpreted in the spirit and purpose of why the International Criminal Court came into being in the first place. ${ }^{514}$ The purpose of the International Criminal Court is to ensure that serious crimes which concerns the international community must be punished. ${ }^{515}$ Therefore the International Criminal Court could not have intended that an individual who knowingly uses slave labour and whose primary purpose is to make profits should

\footnotetext{
${ }^{504} \mathrm{Ibid}$

${ }^{505}$ Ibid

${ }^{506}$ Prosecutor V Furundzija above n 493, Para 40,41

${ }^{507}$ Prosecutor v Furundzija above n 493 ,Para 45

${ }^{508}$ Prosecutor v Furundzija above n 493, Para 48

${ }^{509}$ Prosecutor v Furundzija above n 493,Para 245

${ }^{510}$ Ibid

511 Prosecutor $v$ Furundzija above n 493, Para 275

${ }^{512}$ See Rome Statute above n 34,art 25 (3) ( c ) . Also See Doug Cassel above n 478,313

${ }^{513}$ Ibid

${ }^{514}$ Ibid

${ }^{515} \mathrm{Ibid}$
} 
go unpunished. ${ }^{516}$ The majority of the post World War II cases and the ICTY cases requires that those who aid and abet merely have knowledge that they are assisting criminal activity. ${ }^{517}$ As such it is arguable that the proper mens rea test for aiding and abetting liability is the knowledge test. ${ }^{518}$

\section{O Have The Officials of TNCs In Burma Satisfied the Actus Reus and Mens Rea Requirement of Aiding And Abetting the Crime of Enslavement Under International Criminal Law in Burma?}

Looking at the requirements as laid down by the ICTY case of $\mathrm{R} \mathrm{v}$ Furundzija the test as to whether the Actus Reus for aiding and abetting is satisfied is a two fold test, in that the act of the aider and abettor must include either practical assistance, encouragement or moral support. ${ }^{519}$ However either the practical assistance, encouragement or moral support must have a substantial effect which ultimately leads to the crime being committed. ${ }^{520}$ As such if the aider and abettor has given moral support but this does not have a substantial effect on the perpetration of the crime then the aider and abettor may not have satisfied the actus reus requirement. ${ }^{521}$

In the case of the TNCs in Burma the question that needs to be asked is whether the TNCs in Burma have given practical assistance, encouragement or moral support and has this lead to a substantial effect which has ultimately led to the crime of slave labour being committed in Burma? The TNCs have encouraged these abuses by the Junta by continuing to do business with the Junta for years. ${ }^{522}$ The TNCs have assisted the military junta in the perpetration of these crimes by giving assistance in the form of continued business support for decades, ${ }^{523}$

\footnotetext{
516 Ibid

${ }^{517}$ For instance see United States of America v Carl Krauch And Twenty Two Others above n 37 , 1179

518 Ibid

${ }^{519}$ Prosecutor v Furundzija above n 493 , Para 249

${ }^{520}$ Ibid

521 Ibid

${ }^{522}$ For instance Total has been operating in Burma for almost two decades.Human Rights abusesShwe Gas Movement www.shwe.org (accessed 12 July 2010)

523 Ibid
} 
employing security guards of the Junta regime to guard the pipelines which eventually leads to the perpetration of crimes such as slave labour. ${ }^{524}$

In Burma TNCs such as Total, Chevron and PTTETT have signed joined ventures with the Junta in Burma for the exploration and extraction of oil and gas in Burma. ${ }^{525}$ In furtherance of these joint venture programmes, at the initial stages of the project the TNCs do request the Junta to provide security for the pipelines. ${ }^{526}$ The TNCs have become business partners with the Junta even though the human rights situation in Burma such as the extensive use of forced labour has been condemned repeatedly by the United Nations. ${ }^{527}$ The TNCs by signing joint venture projects with the Junta in Burma and by working closely with the Junta in the extraction projects which involve the Junta army providing security along the pipelines $^{528}$ would amount to the TNCs giving practical assistance, encouragement and moral support to the Junta.

The next issue that needs to be considered is that whether the practical assistance, encouragement or moral support that has been given by the TNCs to the Junta has had a substantial effect on the perpetration of the crime, here the specific crime being the Crime Against Humanity of Slave labour. Where the TNCs in Burma are concerned when the TNCs signed the Joint Venture with the Junta and when the TNCs had requested for security to guard the pipelines, ${ }^{529}$ all these are a form of encouragement to the Junta which subsequently had a substantial effect on the commission of the crime of slave labour. ${ }^{530}$ This is because as soon as the business deals were signed by the Junta and the TNCs this resulted in forced labour being used by the Junta for various works along the pipelines such as clearing the lands along the pipelines and building military barracks. $^{531}$

\footnotetext{
${ }^{524}$ See HRC Resolution 10/27 above n 3, para 112

525 The Pipeline To Riches www.bangkokpost.com (accessed 11 April 2010)

${ }^{526}$ Report on HRC Resolution 10/27 above n ,3 Para 112

${ }^{527}$ Ibid Also See Summary of Report on HRC Resolution 10/27 above n 3

528 Ibid

${ }^{529}$ See Human Rights abuses -Shwe Gas Movement www.shwe.orgg (accessed 12 July 2010)Also see HRC Resolution 10/27, above n 3, para 112

${ }^{530}$ Ibid

531 The Pipeline To Riches www.bangkokpost.com (accessed 14 April 2010)
} 
The next issue that has to be addressed is that, has the officials of the TNCs in Burma satisfied the mens rea requirement for aiding and abetting the crime of slave labour. The proper test will be the knowledge test. ${ }^{532}$ Do the officials of the TNCs in Burma have the knowledge that the crime of slave labour is being committed in Burma?

In 1995 approximately thirty six months after Unacol had acquired its interest in the Yadana project, Imle the Unacol President at a meeting with human rights groups had clearly acknowledged that he had knowledge about the human rights abuses that were occurring in the Yadana pipeline in Burma as he stated that: ${ }^{533}$

People are threatening physical damage to the pipeline, if you threaten the pipeline there's gonna be more military and that if forced labour goes hand and glove with the military yes there will be more forced labour.

Unacol's knowledge on the human rights situation in Burma generally and the use of forced labour in Burma especially along the Yadana pipeline was further enlightened when a consultant that was hired by Unacol John Hasseman had stated that: ${ }^{534}$

Based on my three years of service in Burma, my continuous contacts in the region since then and my knowledge of the situation there, my conclusion is that egregious human rights violations have occurred, and are occurring now in Southern Burma. The most common are forced relocation without compensation of families from land near/along the pipeline route; forced labour to work on infrastructure projects supporting the pipeline and imprisonment and /or execution by the army of those opposing such actions. Unacol by seeming to have accepted the Myanmar Military's version of events appears at best naïve and at worst a willing partner in the situation.

The statements above indicate that officials of Unacol had knowledge about the crimes such as forced labour that was occurring in Burma and it is arguable

\footnotetext{
${ }_{532}^{532}$ See Doug Cassel aboven 474,313

${ }_{533}$ Doe v Unacol http://asialaw.tripod.com (accessed 21 April 2009)

${ }^{534}$ Doe v Unacol http://asialaw.tripod.com(accessed 21 April 2009)
} 
that TNCs and the officials of TNCs that are operating in Burma today such as Chevron, Total and PTTETT also have the requisite knowledge that the crime of slave labour is occurring in Burma. ${ }^{535}$ This can be deduced as violations of the law such as forced labour that occurs in Burma are not isolated incidents but it is a continuous series of violations and abuses which is known worldwide. ${ }^{536}$

\section{P CONCLUSION}

Based on the above analysis it can be concluded that the officials of TNCs in the Yadana project in Burma could be liable under International Criminal Law for being complicit by aiding and abetting the Junta in committing the crime against humanity of slave labour in Burma.

\footnotetext{
${ }^{535}$ See Rajeshree Sisodia, Andrew Buncombe "Burmese villagers forced to work on Total pipeline" (14 August 2009) The Independent, Asia

${ }^{536}$ See Summary on HRC Resolution 10/27 above n 3
} 
In this chapter it will be analyzed whether the war crime of plunder and pillage is being committed in Burma and whether the officials of TNCs in Burma could be liable under International Criminal law for being complicit with the Junta for committing the war crime of plunder.

A The Development of the Law in Relation to the War Crime of Plunder.

In the industrialists cases of IG Farben, Krupp and Flick which were dealt with in Chapter 3, the indictment against the industrialists for offences against property the term plunder was used. ${ }^{537}$ However in the Hague Regulations the term that is used is pillage. ${ }^{538}$ In the ICTY case of Mucic it was stated that the traditional term of pillage denotes that some force or assault was involved when the act of pillage occurred. ${ }^{539}$ In the case of Flick the Tribunal stated that Flick had committed the crime of plunder when he had tempered with the contracts to ensure that his interests was protected and in this particular act of plunder committed by Flick no assault or force was involved. ${ }^{540}$ Here the term plunder and pillage will be used interchangeably.

Plunder is a war crime. ${ }^{541}$ Historically during war the enemy could arbitrarily appropriate the property of the other party to the conflict. ${ }^{542}$ However the laws and customs of law have developed through the years and today International law has laid down limitations in the appropriation of public and

\footnotetext{
${ }^{537}$ The three industrialists were indicted for the plunder of public and private properties.

538 See Convention (IV) respecting the Laws and Customs of War on Land and its annex:

Regulations concerning the Laws and Customs of War on Land.The Hague, 18 October 1907 above n 184

${ }^{539}$ See Prosecutor v Mucic (IT-96-21-T) (Trial Chamber) (Judgment) (16 November 1998) Para 591

${ }^{540}$ In the case of Flick he had inserted a clause which would enable him to obtain the properties. The Tribunal held this was an act of plunder

${ }_{541}$ See Prosecutor v Mucic above n 539, Para 539

${ }^{542}$ Prosecutor $v$ Mucic above n 539, Para 539
} 
private property by the enemy during armed conflicts. ${ }^{543}$ Hague Regulations 1907 is the regulation annexed to the Hague Convention of 1907 which deals with respecting the customs and laws of war on land. ${ }^{544}$ Article 28 of the Hague Regulations states "The pillage of a town or place even when taken by assault is prohibited" ${ }^{345}$ further "Pillage is formally forbidden"546 is stated in Article 47. ${ }^{547}$ Article 47 refers to situations where the military has taken over a territory of the hostile state, in such a situation the military is prohibited from committing the act of pillage in the hostile state. ${ }^{548}$ Respect for private property is also provided under the four Geneva Conventions of 1949 where Article 18 which is contained in the Second Geneva Convention states that when there is a conflict the parties to the said conflict must ensure that the shipwrecked, wounded and sick is protected from pillage. ${ }^{549}$ Article 33 of Geneva Convention IV states that "Pillage is Prohibited" ${ }^{, 550}$ and the rule in Article 33 applies to protected persons during times of war that is the parties to the international conflict are prohibited from committing pillage against these protected persons even in times of war. ${ }^{551}$ Common Article 3 of the Four Geneva Conventions was a breakthrough in the field of armed conflict as it covers situations involved in non international armed conflict which includes traditional civil wars and internal armed conflicts ${ }^{552}$ Common Article 3 does not make a reference specifically to pillage. ${ }^{553}$ There are

\footnotetext{
${ }^{543}$ Prosecutor v Mucic above n 539, Para 539.Also see Kevin Riordan "Protecting Fundamental Human Rights In Times Of War-The Means And Methods of Warfare"(2005)NZLR 1,8

${ }^{544}$ See Convention (IV) respecting the Laws and Customs of War on Land and its annex: Regulations concerning the Laws and Customs of War on Land.The Hague, 18 October 1907 above $\mathrm{n} 261$

${ }^{545}$ See Convention (IV) respecting the Laws and Customs of War on Land and its annex: Regulations concerning the Laws and Customs of War on Land.The Hague, 18 October 1907, above n 261, art 28

${ }^{546}$ See Convention (IV) respecting the Laws and Customs of War on Land and its annex: Regulations concerning the Laws and Customs of War on Land.The Hague, 18 October 1907above n 261, art 47

${ }^{547}$ Ibid

${ }^{548}$ Ibid

${ }^{549}$ See Convention (II) for the Amelioration of the Condition of Wounded, Sick and Shipwrecked Members of Armed Forces at Sea.Geneva, 12 August 1949 (entered into force 21 October 1950)art 18

${ }^{550}$ See Convention (IV) relative to the Protection of Civilian Persons in Times Of War, above $\mathrm{n}$ 278 , art 33

${ }^{551}$ Ibid

${ }^{552}$ Convention (III) relative to the Treatment of Prisoners of War.Geneva, 12 August 1949 (adopted 12 August 1949, entered into force 21 October 1950) art 3

${ }^{553}$ Ibid
} 
two protocols additional to the Geneva Conventions of 1949 which were adopted in $1977 .{ }^{554}$ The Additional Protocol I to The Geneva Conventions of 1949 relates to the protection of victims in International Armed Conflicts ${ }^{555}$ and The Additional Protocol II to The Geneva Conventions of 1949 provides for the protection of victims in non international armed conflicts. ${ }^{556}$ Article 4 (2) (g) contained in Additional Protocol II of The Geneva Conventions 1949 states that "pillage is prohibited" "557 This Article is applicable against persons who are no longer taking part in the hostilities and who do not in a direct manner participate in the hostilities. ${ }^{558}$ For the applicability of this article on these persons it is irrelevant whether these persons have restricted liberty or non restricted liberty. ${ }^{559}$

Burma had ratified the Four Geneva Conventions of 1949 in $1992 . .^{560}$ However Burma has not ratified any of the additional Protocols of the Geneva Conventions of $1949 .^{561}$

\section{B The Contemporary Law of Plunder.}

With the emergence of the International Criminal Court, the war crime of pillage was enshrined in the Rome Statute. ${ }^{562}$ Article 8 (1) of the Rome Statute states that "The Court shall have jurisdiction in respect of war crimes in particular when committed as part of a plan or policy or as part of a large-scale commission of such crimes." 563 The war crime of pillage is codified under Article 8 (2) (b) (xvi) and $8(2)(\mathrm{e})(\mathrm{v}){ }^{564}$ Pursuant to Article $8(2)(\mathrm{b})(\mathrm{xvi})$ the crime of pillage is a war crime under International Criminal Law when there is an international

\footnotetext{
${ }^{554}$ These two protocols covers international armed conflicts and non international armed conflicts

${ }^{555}$ See Protocol Additional to the Geneva Conventions of 12 August 1949, and relating to the Protection of Victims of International Armed Conflicts (Protocol I), 8 June 1977 (adopted 8 June 1977, entered into force 7 December 1978)

${ }^{556}$ See Protocol Additional to the Geneva Conventions of 12 August 1949, and relating to the Protection of Victims of Non-International Armed Conflicts (Protocol II), 8 June 1977 ( adopted 8 June 1977, entered into force 7 December 1978)

${ }_{557}^{57}$ See Protocol Additional II To The Geneva Convention above n 556, art 4 (2) (g)

${ }^{558}$ Ibid

${ }^{559}$ Ibid

${ }^{560}$ Myanmar-International treaties adherence www.adh-geneva.ch (accessed 11 February 2010)

${ }_{561}^{56}$ Myanmar-International treaties adherence www.adh-geneva.ch (accessed 11 February 2010)

${ }^{562}$ See Rome Statute, above n 34,art 8 (1)

${ }^{563} \mathrm{Ibid}$

${ }^{564}$ See Rome Statute above n 34, art 8 (2) (b) (xvi) and art 8 (2) (e) (v) These codifications relates to the crime of pillage under different armed conflict situations
} 
armed conflict and pursuant to Article 8 (2) (e) (v) pillage is a war crime under International Criminal Law when there is a non International Armed Conflict. ${ }^{565}$ Further Article 8 (2) (f) clarifies the nature of the armed conflict that should exist for the applicability of Article 8 (2) (e) (v). ${ }^{566}$ Article 8 (2) (f) states as follows: ${ }^{567}$

Paragraph 2 (e) applies to armed conflicts not of an international character and thus does not apply to situations of internal disturbances and tensions, such as riots, isolated and sporadic acts of violence or other acts of a similar nature. It applies to armed conflicts that take place in the territory of a state when there is protracted armed conflict between governmental authorities and organized armed groups or between such groups.

\section{The War Crime of Plunder}

Here it will be analyzed whether the crime of plunder is occurring in Burma. Plunder is a war crime. ${ }^{568}$ Therefore for the crime of plunder to take place in Burma there has to be an international armed conflict or a non international armed conflict occurring in that country. ${ }^{569}$ The first fact that has to be analyzed is that whether there is an armed conflict in Burma at all and if so, whether it is an international armed conflict or a non international armed conflict.

\section{The Armed Conflict in Burma}

Since Burma obtained its independence in 1948 it has been in a state of almost continuous civil war. ${ }^{570}$ This is largely due to the fact that prior to independence at the request of Aung San the Pagalog Agreement was signed by the ethnic minorities in Burma to safeguard their interests in Burma. ${ }^{571}$ However

\footnotetext{
${ }^{565}$ See Rome Statute above n 34, art 8 (2) (f) and art 8 (2) (e) (v). The ICTY cases clarifies in detail as to how to distinguish situations as international armed conflicts and non international armed conflicts

${ }^{566}$ See Rome Statute, above n 34, art 8 (2) (f)

567 Ibid

${ }^{568}$ See Prosecutor v Mucic above n 539, Para 585

${ }^{569}$ See Prosecutor v Mucic above n 539 Para 585

${ }^{570}$ See James D Fearon, David D Laitin above n 13,2

${ }^{571}$ See Angelene Naw above n 12, 193
} 
with the untimely demise of Aung $\operatorname{San}^{572}$ the minorities in Burma concerned that their interests contained in the Pagalog agreement will not be realized took up arms against other minorities and against the then government of Burma. ${ }^{573}$ The civil war that existed in 1948 in Burma still prevails in Burma today. ${ }^{574}$ The Junta in Burma sustains an army of more than 400,000.00 soldiers. ${ }^{575}$ The Junta's army known as the Tatmadaw is one of the largest armies in South East Asia despite the fact that Burma has no external enemies. ${ }^{576}$

In the jurisdiction appeal case concerning Jurisdiction in Prosecutor v Tadic, the Appeals Chamber explained the circumstances that would give rise to the existence of an armed conflict: ${ }^{577}$

An armed conflict exists whenever there is a resort to armed forces between States or protracted armed violence between governmental authorities and organized armed groups or between such groups within a State.

The Appeals Chamber went on further to state that:- ${ }^{578}$

International Humanitarian Law applies from the initiation of such armed conflict and extends beyond the cessation of hostilities until a general conclusion of peace is reached; or in the case of internal conflicts, a peaceful settlement is achieved. Until that moment, international humanitarian law continues to apply in the whole territory of the warring States or in the case of armed conflicts, the whole territory under the control of a party whether or not actual combat takes place there.

Applying the law stated in the Tadic case to the situation in Burma this will mean that as many states in Burma such as the states of Shan, Karen, and the

\footnotetext{
${ }^{572}$ Aung San and six of his ministers were assassinated at a cabinet meeting prior to the independence of Burma.

573 James D Fearon, David D Laitin above n 13,2

574 See HRC Resolution 10/27 above n 3, Para 66

${ }^{575}$ See Mathea Falco Burma :Time For change : Report o Independent Task Force (prepared for the council of foreign relationsof United states Of America ,2003)

576 See Min Lwin "Regime Goal: The Strongest Army in Southeast Asia" (20 August 2009) The Irrawaddy, covering Burma and Southeast Asia. Since independence Burma is at peace with its neighbours such as Thailand, India and Malaysia.

577 Prosecutor v Tadic (IT-94-1-A)(Appeal Chamber)(Judgment) (2 October 1995) Para 70

578 Ibid
} 
Pegu division is involved in armed conflict and as the soldiers from the state army that is the Tatmadaw are in these states and as no peaceful settlement has been reached between the state army and the armed groups, as such International Humanitarian Law will apply to these states in Burma that is facing the armed conflict even if there is no actual combat taking place in those territories. ${ }^{579}$

In Burma many districts are still subject to armed conflict not of an international character. ${ }^{580}$ The armed conflict in Karen state and Shan state has intensified in recent years. ${ }^{581}$ In March 2007 the Junta Army and its ally Democratic Karen Buddhist Army (DKBA) had launched offensives against the armed wing of Karen National Union (KNU) that is the Karen National Liberation Army (KNLA) in Karen state. ${ }^{582}$ The Junta and DKBA had also launched offensives in Papuan district which resulted in the reported deaths of three people and 400 villagers fled the scene of the conflict. ${ }^{583}$ Subsequent to this from April 2007 the fighting between Junta army, DBKA and KNLA became intense in the districts of Toungoo, Nyaunglebin, Papun and Thaton. ${ }^{584}$ The armed forces of Junta and DBKA had targeted the KNLA's $7^{\text {th }}$ Brigade and as a result of this offensive 41 people were reported to be killed, therefore KNLA had no choice but to abandon its headquarters located in the north side of Myanwady. ${ }^{585}$ Fighting abated between July and November 2007 only to resume in November 2007 and Karen NGO's had reported that throughout 2007 Karen villagers were abused by the Junta army and this fact was confirmed by the United Nations Report in $2008 .^{586}$ In 2008 the Junta and the DBKA resumed its offensive against KNU where the fighting between DKBA and KNLA intensified in November 2008 which led to 500 Karen villagers seeking shelter in the Thai border. ${ }^{587}$ In 2009 the

\footnotetext{
${ }^{579}$ See Report on HRC Resolution 10/27, above n 3, Para 61, Para 66 Also See HRC Resolution 5/1, above n 261, Para 69

${ }^{580}$ Ibid

${ }^{581}$ Ibid

582 IISS Armed Conflict Database Annual Update 2007 http://acd.iiss.org/armedconflict (accessed 14 April 2010)

${ }^{583}$ Ibid

${ }^{584} \mathrm{Ibid}$

${ }^{585} \mathrm{Ibid}$

${ }^{586}$ Ibid. See HRC Resolution 5/1, above n 261, Para 77.

${ }^{587}$ IISS Armed Conflict Database http://acd.iiss.org Annual Update 2008 (accessed 14 April 2010)
} 
Junta army started its operation in the areas held by the KNLA's $5^{\text {th }}$ Brigade. $^{588}$ In June 2009 another major offensive was launched by DBKA into the Karen territory which resulted in the fall of several bases belonging to KNLA including KNLA's $7^{\text {th }}$ brigade headquarters base. ${ }^{589}$ In 2007 the reported casualties due to armed conflict was 407 and in 2008 the death toll due to armed conflict was $66 .{ }^{590}$ To date the armed opposition has not conquered any territory in Burma as these armed groups are outweighed in numbers as the Junta army has about 450,000.00 soldiers. $^{591}$

The Special Rapporteur in his report to the United Nations had made the following statement with regards to the situation in Karen state: ${ }^{592}$

It has been reported that, in Karen State over 40,000 villagers have been internally displaced. At least 10 villagers in Karen state are said to have been killed and thousands rendered homeless owing to an increased army presence over the past months. According to reports in December 2007, there were 187 army battalions in Karen state, including the three districts, with at least 120 to 150 soldiers in each battalion.

The Special Rapporteur assigned to Burma had made the following statements on the point of armed conflict in Burma in his report to the United Nations General Assembly. ${ }^{593}$ He stated that "The majority of new internal displacement and forced migration were concentrated in North East Karen State and adjacent areas of Pegu Division still subject to armed conflict" ${ }^{\circ 94}$ In the same report he voiced his concern over military operation that was rampant in the ethnic areas and stated that "the government and non state armed groups have the obligation under International Humanitarian Law to take appropriate measures to protect the civilian population against the effects of conflict." ${ }^{, 595}$ In March 2010

\footnotetext{
${ }^{588}$ IISS Armed Conflict Database http://acd.iiss.org Annual Update 2009 (accessed 14 April 2010) 589 Ibid

${ }^{590}$ IISS Armed Conflict Database http://acd.iiss.org Annual Update 2007,2008 (accessed 14 April 2010)

${ }^{591}$ See Mathea Falco, above n 575

${ }^{592}$ See HRC Resolution 5/1, above n 261, Para 77

593 Ibid

${ }^{594}$ HRC Resolution 5/1, above n 261, Para 69

${ }^{595}$ HRC Resolution 5/1, above n 261, Para 72
} 
the Special Rapporteur to Burma had also stated in his report that armed conflict was raging in the Shan state. In his report he stated that: ${ }^{596}$

Battles between Government forces and ethnic groups in Shan State in August 2009 and along the Thai border region in June 2009 have raised serious concerns about security both inside Myanmar and its spill over effects in neighbouring countries. As many as 37,000 people have fled into Nansen county in China to flee fighting between Myanmar Government troops and Kokang fighters.

As observed by the Special Rapporteur Eastern Burma is subject to intense armed conflict and the Shan state and the Karen state are in Eastern Burma. ${ }^{597}$ It is important to note that the Yadana and Yetagun pipelines passes through Eastern Burma. ${ }^{598}$ The Yadana and Yetagun pipelines are built in connection with the Yadana and Yetagun projects which is one of the first and biggest joint venture agreement entered into by the Junta and the various TNCs in Burma. ${ }^{599}$ Before the Yadana pipeline was constructed a few routes were available to the Junta to construct the pipelines, however the Junta chose the pipeline route that cuts across the area where the Karen and Mon minorities live in Burma. ${ }^{600}$ This route gave the Junta an excuse and a subsidised means to keep the minorities under the control of the Junta and its army. ${ }^{601}$ Total has been accused of assisting the military in its fights against the ethnic minority rebels in the Tennaserim division in Eastern Burma through which the pipelines passes. ${ }^{602}$ Further Total has also been accused of loaning helicopters and pilots to the Junta but it has denied these facts however sources within the company confirmed that the allegations were true. $^{603}$

\footnotetext{
${ }^{596}$ Ibid. Also See Report on HRC Resolution 10/27 above n 3, Para 66

${ }^{597}$ See report on HRC Resolution 10/27 above n 3, Para 66.

${ }^{598}$ Human Rights abuses -Shwe Gas Movement www.shwe.org (accessed 12 July 2010)

${ }^{599}$ Ibid.See HRC resolution 10/27, above n 3, Para 102.

${ }^{600}$ Philip Swanson Fuelling Conflict The oil Industry and armed conflict (Fafo Report 378) 29,30

${ }^{601}$ Ibid

${ }^{602}$ Philip Swanson Fuelling Conflict The Oil Industry and Armed Conflict above n 600,30

${ }^{603}$ Philip Swanson Fuelling Conflict The Oil Industry and Armed Conflict above n 600,29
} 
Based on the above facts, the ICTY case law on the issue of armed conflict and the Reports of the Special Rapporteur to Burma it can be concluded that there is a non international armed conflict that is occurring in Burma.

\section{E The Crime of Plunder in Burma?}

The next issue that will be analyzed is whether the war crime of pillage is occurring in Burma. For the purpose of this analysis the elements of pillage found in Article 8 (2) (e) (v) will be used. ${ }^{604}$ Article 9 of the Rome Statute of the International Criminal Court states that the elements of the crime can assist the court in interpreting and applying war crimes, crimes against humanity and Genocide, however the elements of the crimes does not have a binding effect on the judges. ${ }^{605}$

\section{F Elements of the War Crime Of Pillage under Article 8 (2) (e)( v) of the International Criminal Court .}

The elements of war crimes for the war crime of pillage is as follows: ${ }^{606}$

1. The Perpetrator appropriated certain property

2. The Perpetrator intended to deprive the owner of the property and to appropriate it for personal use

3. The appropriation was without the consent of the owner

4. The conduct took place in the context of and was associated with an armed conflict not of an international character

5. The Perpetrator was aware of factual circumstances that established the existence of an armed conflict

In dealing with the first element the argument here is that the Perpetrator in Burma that is the Junta has appropriated property from the people. ${ }^{607}$ The first

\footnotetext{
${ }^{604}$ See Rome Statute above n 34, art 8 (2) (e) (v)

${ }^{605}$ See Rome Statute above n 34, art 9

606 Ibid

${ }^{607}$ See HRC Resolution 5/1, above n 261, Para 64
} 
appropriation involves the Junta confiscating lands that belong to the people without paying the people any compensation. ${ }^{608}$ The Special Rapporteur to Burma in 2008 had documented some of the events that is taking place in Burma which involves arbitrary land confiscation and armed conflict in various states in Burma. $^{609}$ In the report submitted to the United Nations he had stated that: ${ }^{610}$

Para 64 The Special Rapporteur notes the increasing recognition among human rights, humanitarian and development groups of the need to document issues related to land and natural resource management in Myanmar. Arbitrary land confiscations throughout the country are another illustration of the culture of impunity prevailing in Myanmar. While the Government claims that land is "State owned property", on the basis of the Land Nationalization Act of 26 October 1953 conferring land ownership on the State, these confiscations appear to have several aims, including relocating civilian population deemed to be sympathetic to the armed opposition; anchoring a military presence in disputed areas; and opening the way for infrastructure development projects.

Land confiscation is rampant in Burma where the people's land are confiscated and this leads to internal displacement and forced migration. ${ }^{611}$ In the said report to the United Nations the Special Rapporteur had stated that "the internal displacement and forced migration were concentrated in north-east Karen state and adjacent areas of Pegu division, still subject to armed conflict.",612 Further in his report he had also noted that "protection from land confiscation depends on settlement of the conflicts that have wracked the country for more than half a century." 613

The second form of appropriation of property involves the exploitation of natural resources within the land of Burma. ${ }^{614}$ It is arguable that when the natural resources in a country is exploited to a large extent without benefitting the people of the country this act of exploitation done by the Junta can also be termed as

\footnotetext{
608 Ibid

609 Ibid

610 Ibid

${ }^{611}$ See HRC Resolution 5/1, above n 261, Para 69

612 Ibid

${ }^{613}$ HRC Resolution 5/1, above n 261, Para 68

${ }^{614}$ HRC Resolution 10/27, above n 3, Para 111
} 
appropriating property. The Special Rapporteur had in his report to the United Nations given a statement in relation to projects involving the extraction of natural resources in Burma, where these projects benefits the foreign companies and the Junta government but has a negative impact on the country. ${ }^{615}$ In his report it was stated that: ${ }^{616}$

\begin{abstract}
The extraction of natural resources, notably offshore gas, is providing various interest groups including the military and foreign companies, with business opportunities. Economic concessions, including some for logging and mining, have been granted. This policy has led to numerous forced evictions, relocations and resettlements, especially in rural areas but also in urban areas, particularly in connection with the move of the capital from Yangon to Nay Pyi Taw.
\end{abstract}

The current Special Rapporteur to Burma in his report to the United Nations in 2010 had also stated that: ${ }^{617}$

The alarming depletion of natural resources in Myanmar is of concern as is the relationship between the extractive industries and a vast array of human rights violations. In Myanmar the mining of gold, gemstones, copper and other plentiful mineral resources has been linked to land confiscation, forced labour and violations of the right to a healthy environment and the right to water.

This unlawful appropriation of property by the Tatmadaw soldiers occurs in line with the developmental projects that takes place in Burma. ${ }^{618}$ In the reports to the United Nations such incidents are recorded as follows: ${ }^{619}$

The Projects are being implemented under an agreement signed in late 2006 with the State- owned China Power Investment Corporation. During construction, a number of human rights abuses in the local areas has been reported following the arrival of the Light Infantry Battalion 121. The army is reportedly forcing villagers to pave the

\footnotetext{
${ }^{615}$ See HRC Resolution 5/1 above $\mathrm{n} 261$, Para 66

${ }^{616}$ Ibid

${ }^{617}$ Report on HRC Resolution 10/27, above n 3, Para 111

${ }^{618}$ Report on HRC Resolution 5/1 above n 261, Para 65

${ }^{619}$ Ibid
} 
routes and is extorting money from local merchants, taking materials from shops and farms without paying.

Based on the above it can be concluded that the first element that is the perpetrator appropriating certain property is satisfied.

With regards to the second element there are two factors that need to be satisfied, firstly that the perpetrator intended to deprive the owner of the property and second the property was appropriated for personal use. ${ }^{620}$ In the situation in Burma in committing the act of confiscating the land, in severe exploitation of natural resources and taking properties such as money from the villagers; the Junta and the Tatmadaw soldiers do have the intent to deprive the owner of the property. ${ }^{621}$ This is clear as the villagers are not compensated by the Junta government when their properties are confiscated. ${ }^{622}$ Further the Tatmadaw that steals the properties belonging to the villagers do not return those properties to the owners. ${ }^{623}$ The term personal use here should not be construed restrictively and should not be equated with individual use, as to do so may defeat the purpose behind the reason the element was added in as an element of the crime. When the Junta uses the proceeds of the plunder for the upkeep of its army this could also come under the ambit of personal use of the Junta as the army is under the exclusive control of the Junta and benefits the Junta and is used by the Junta to accomplish its purposes. ${ }^{624}$ Therefore if the proceeds of plunder is used by the Junta to upkeep the army then this can be construed to mean that it is being used by the Junta for its personal use. As such it is arguable that this element is satisfied as these properties were appropriated for the personal use of the Junta .

In relation to the third element in Burma when lands are arbitrarily confiscated from the people in Burma these people do not consent to the Tatmadaw taking their lands but are forced to surrender their lands to the

\footnotetext{
${ }^{620}$ See Rome Statute above n 34, art 8 (2) (e) (v)

${ }^{621}$ See HRC Resolution 5/1, above n 261, Para 64, 65,66.

${ }^{622}$ Ibid Also See HRC Resolution 5/1 above n 261, Para 67

${ }^{623}$ Ibid

${ }^{624}$ See Report on HRC Resolution 10/27, above n 3,Para 98,Para 111, Para 112
} 
Tatmadaw. ${ }^{625}$ The consent is also not in existence when the soldiers appropriate certain property from the people. ${ }^{626}$ Further when the Junta signs project deals with foreign companies for the extraction of natural resources, the people are not even informed that such projects are going to take place in their town or village as such it is clear that in this situation as well consent was not obtained from the people. $^{627}$

The fourth element states that "the conduct took place in the context of and was associated with an armed conflict not of an international character.",628

Two factors need to be fulfilled to satisfy the fourth element that is firstly there must be an armed conflict and the second factor is that the nexus between the conduct of appropriating the property and the armed conflict must be established. ${ }^{629}$ To satisfy the fourth element it has to be proved that the conduct that is the appropriation of the property took place in the context of and was associated with armed conflict not of an international character. ${ }^{630}$

The existence of an armed conflict has been proven above as such the next element that has to be proved is the nexus between the appropriation and the armed conflict.

\section{G The Nexus Between the Crime and the Armed Conflict.}

A link has to be established between the criminal act and the armed conflict. ${ }^{631}$ There may be situations where certain crimes in a territory may take place when there is fighting during an armed conflict. ${ }^{632}$ When this happens the offence committed would be a violation under International humanitarian Law. ${ }^{633}$ However such a direct link between the crimes and armed conflict is not required

${ }^{625}$ See HRC Resolution 5/1 above n 261, Para 64

${ }^{626}$ See HRC Resolution 5/1 above n 261,Para 65

${ }^{627}$ See HRC Resolution 5/1 above n 261, Para 66. Also see HRC Resolution 10/27, above n 3, Para 112

${ }^{628}$ See Rome Statute above n 34, art 8 (2) (e) (v)

${ }^{629}$ Ibid

${ }^{630} \mathrm{Ibid}$

${ }^{631}$ See Prosecutor v Mucic, above n 539, Para 193

${ }^{632}$ Ibid

${ }^{633}$ Ibid 
in all situations. ${ }^{634}$ In the Appeals Chamber in Tadic in stating the courts view on the nexus requirement between the crime and the armed conflict the court had stated that "it is sufficient that the alleged crimes were closely related to the hostilities occurring in other parts of the territories controlled by the parties to the conflict." $" 635$ This would mean that for International Humanitarian Law to apply there need not be actual combat or hostilities in the certain state or territory. ${ }^{636}$ Further it is also not a requirement that at the time the offence is committed in a certain territory, actual armed conflict should be taking place in that exact period of time in that territory. ${ }^{637}$ Applying this reasoning by the Trials Chamber in the case of Mucic and Tadic to the situation in Burma even in situations where the three acts of appropriation of property that takes place in Burma does not happen at the exact same time during the armed conflict that is taking place in those territories, International Humanitarian Law would still apply to the situation existing in many states in Burma such as in the states of Karen and Shan in Eastern Burma. ${ }^{638}$ As such if it can be proved that the crimes such as arbitrary confiscation of land, appropriation of money and other valuables and the exploitation of natural resources were connected to the hostilities taking place in other parts of the territory which is controlled by parties involved in the conflict then International Humanitarian Law will become operative in those territories. $^{639}$

In Burma land is arbitrarily confiscated in many states in Burma which includes the state of Shan. ${ }^{640}$ Armed conflict in Burma occurs in Eastern Burma in the states of Shan and Karen and the armed conflicts in these States are between the Burma State Army, the Karen Liberation Army and the Shan state army and the Kokang fighters. ${ }^{641}$ Land confiscations in Burma occurs in many other

\footnotetext{
634 Ibid

${ }^{635}$ Prosecutor $v$ Tadic, above n 577, Para 70

${ }^{636}$ Ibid

${ }^{637}$ See Prosecutor v Mucic above n 539, Para 193

${ }^{638}$ See HRC Resolution 10/27 above n 3, para 66

${ }^{639}$ See Prosecutor v Tadic, above n 577 , para 70

${ }^{640}$ See HRC Resolution above n 5/1, above n 261,para 64.Also see Voravit Suwanvanichkij "Displacement and disease: The Shan exodus and infectious disease implications for Thailand" (14 March 2008) Conflict and Health

${ }^{641}$ See HRC Resolution 10/27 above n 3, Para 66. Also see HRC Resolution 5/1, above n 261, para 77.
} 
territories in Burma and these territories are under the power of one of the parties to the conflict that is the Junta army known as the Tatmadaw. ${ }^{642}$ As such here the nexus required between the crime and the armed conflict is met.

The exploitation of natural resources which can amount to appropriation of property is done in many territories in Burma and one of the largest exploitation of natural resources in Burma is done through the creation of the Yadana and Yetagun pipelines which passes through the Tennasserim division and Eastern Burma. ${ }^{643}$ The Shan state and Karen state are in Eastern Burma and as stated above the Shan state and Karen state are territories in Burma which are subject to the armed conflict. ${ }^{644}$ The Tennasserim division is also an area prone to armed conflict. $^{645}$ As such here too the nexus between the armed conflict and the purported crime of appropriation of natural resources is established.

The crime of appropriating money and other valuables from the farm and the villagers in Burma, are committed by the Battalion belonging to a party to the conflict that is the state army of Burma,commonly known as the Tatmadaw which is present at the villages when these crime occurs. ${ }^{646}$ As such it can be said that for this kind of appropriation of property as well the nexus between the crime and armed conflict is established.

The Appeals Chamber in the case of Prosecutor $v$ Kunarac shed more light on the issue of the nexus between the commission of the crime and the armed conflict. $^{647}$ The Appeals Chamber in Prosecutor $v$ Kunarac gave the same definition to armed conflict as in the case of Tadic. ${ }^{648}$ On the issue of the nexus between the armed conflict and the crime the Appeals Chamber stated that: ${ }^{649}$

\footnotetext{
${ }^{642}$ See HRC Resolution 5/1 above n 291, Para 64

${ }^{643}$ See HRC Resolution 10/27 above n 3, Para 111, Para 112.Also see Human Rights Abuses Shwe Gas Movement www.shwe.org (accessed 12 July 2010)

${ }^{644}$ See Report on HRC Resolution 10/27 above n 3, Para 66. Also See HRC Resolution 5/1 above n 261, para 69.

${ }^{645}$ See Ashley South “Burma The Changing Nature Of Displacement Crises” RSC Working Paper No.39 (Paper prepared in conjunction with the RSC workshop 'Conflict Violence and Displacement in Burma' (2006)

${ }^{646}$ See HRC resolution 5/1 above $\mathrm{n}$ 261, Para 65

${ }^{647}$ See Prosecutor v Kunarac above n 326,Para55

648 Ibid

${ }^{649}$ Prosecutor v Kunarac above n 326, para 57,60
} 
There is no necessary correlation between the area where the actual fighting is taking place and the geographical reach of the laws of war. The laws of war apply in the whole territory of the warring states, or in the case of internal armed conflicts, the whole territory under the control of a party to the conflict, whether or not actual combat takes place there, and continue to apply until a general conclusion of peace or, in the case of internal armed conflict until a peaceful settlement is achieved. A violation of laws may therefore occur at a time when and in a place where no fighting is actually taking place. As indicated by the Trial Chamber, the requirement that the acts of the accused must be closely related to the armed conflict would not be negated if the crimes were temporarily and geographically remote from the actual fighting .It would be sufficient, for instance, for the purpose of this requirement , that the alleged crimes were closely related to hostilities occurring in other parts of the territories controlled by the parties to the conflict.

The Appellants' proposition that the laws of war only prohibit those acts which are specific to an actual wartime situation is not right. The laws of war may frequently encompass acts which though they are not committed in the theatre of conflict, are substantially related to it.

The Appellants in this case had argued that the armed conflict only existed in an area known as Foca and that they had taken part in the armed conflict in Foca. ${ }^{650}$ The Appellants also argued that the armed conflict did not exist in the neighbouring municipalities. ${ }^{651}$ In response to this argument the Appeals Chamber in the case of Kunarac stated that: ${ }^{652}$

The Appeals Chamber notes that the municipalities of Ga-ko and Kalinovik are contiguous and neighboring municipalities of Foca. Furthermore the Appeals Chamber considers that the Prosecutor did not have to prove that there was armed conflict in each and every square inch of the general area. The state of armed conflict is not limited to the areas of actual military combat but exists across the entire territory under the control of the warring parties.

The Appeals Chamber does not accept the Appellants; contention that the laws of war are limited to those acts which could only be committed in actual combat.

${ }^{650}$ Prosecutor $v$ Kunarac above n 326, para 64

651 Ibid

${ }^{652}$ Prosecutor v Kunarac above n 326, para 64,65 
Instead, it is sufficient for an act to be shown to have been closely related to the armed conflict, as the Trial Chamber correctly found.

Applying this precedent to the situation that is prevalent in Burma the laws of war would apply to many territories in Burma such as the territory of Shan, Karen and the Tennasserim division where all these states and territories are in Eastern Burma. ${ }^{653}$ As such in Burma even if actual combat is not taking place in that certain territory in Eastern Burma the laws of war would still be applicable in Eastern Burma as the Junta Army in Burma, is still engaged in intense armed conflict in Shan State with the Kokang fighters. ${ }^{654}$

The Appeals Chamber in the case of Kunarac also stated that it is not necessary to prove a causal link between the crime committed and the armed conflict, but the armed conflict must have played a vital role in the ability of the perpetrator to commit the crime. ${ }^{655}$ Applying this point to the situation in Burma the appropriation of property which includes the appropriation of lands, the peoples valuables and possession such as money and the natural resources taken from within the land of Burma, these appropriation will not happen, if there was no armed conflict in Burma. ${ }^{656}$ Due to the armed conflict in Burma many of the people of Burma have been reduced to marginal states of life where about 1 million people in Burma are displaced and 500,000.00 of these people have been displaced in Eastern Burma. ${ }^{657}$ When the people of Burma are displaced, homeless and weakened politically, and challenged economically and socially due to the armed conflict in Burma this paves the way for the Junta army to commit these crimes of appropriation of property in various forms. ${ }^{658}$

\footnotetext{
${ }^{653}$ See Protracted crisis in Eastern Burma www.odihpn.org/report (accessed 12 July 2010)Also see Chris Cusano "Burma: Displaced Karens.Like Water on the Khu Leaf" 141

${ }^{654}$ See HRC Resolution above n 10/27,para 66

${ }^{655}$ Prosecutor $v$ Kunarac above n 326, para 58

${ }^{656}$ See HRC Resolution 5/1, above n 261, para 64, para 65, para 66.

${ }^{657}$ Report on HRC Resolution 10/27 above $\mathrm{n} 3$, para 61

${ }^{658}$ For an account of the condition of the people in the Shan State in Burma see HRC Resolution $10 / 27$ above $n 3$, para 65
} 
A five tier factor test was also used by the Appeals Chamber in Kunarac to determine the issue as to whether the commission of a crime is related to the armed conflict. ${ }^{659}$ The five tier factor test would involve the following factors: ${ }^{660}$

The fact that the perpetrator is a combatant, the fact that the victim is not a combatant, the fact that the victim is a member of the opposing party; the fact that the act may be said to serve the ultimate goal of a military campaign; and the fact that the crime is committed as part of or in the context of the perpetrator's official duties.

Applying this five tier factor test to the situation in Burma, in regards to the first factor the perpetrator in relation to the confiscation of the people's land and appropriation of the people's valuable, is the Junta army and the Junta's soldiers known as the Tatmadaw is the perpetrator and the combatant. ${ }^{661}$ The second factor is fulfilled as the people of Burma who lose their land, belongings and natural resources are the victims of these crimes and they are non combatants. ${ }^{662}$ The people in Eastern Burma and other territories could qualify as members "of the opposing party" ${ }^{\prime 63}$ as the people in Shan and Karen and in many other territories in Burma are not members of the Junta army as they could be members of an opposing group such as the Shan State Army, as such this factor is fulfilled. ${ }^{664}$ The fourth factor is fulfilled as when the Tatmadaw arbitrarily confiscates the lands belonging to the people, the people's belongings and when natural resources is exploited ${ }^{665}$ without benefiting the citizens of the country ${ }^{666}$ all these acts are engineered by the Junta to ensure that the majority of the citizens in Burma are economically marginalized and are unable to oppose the Junta and this serves the main aim of the military campaign of the Junta that is to stay in

\footnotetext{
${ }^{659}$ Prosecutor $v$ Kunarac above n 326, para 59

660 Ibid

${ }^{661}$ See HRC Resolution 5/1 above n 261,para 64, para 65

${ }^{662}$ See HRC Resolution 5/1 above n 261, Para 65.The people in Burma whose properties are taken by the Junta and Tatmadaw are the villagers in states such as Shan and Karen and they are not combatants.

${ }^{663}$ Prosecutor $v$ Kunarac above n 326, para 59

${ }^{664}$ See HRC Resolution 5/1, above n 261, para 64

665 Ibid para 64, para 65, para 66

${ }^{666}$ The Junta government spends only $0.5 \%$ of its Gross Domestic Product on health.
} 
power. ${ }^{667}$ The fifth factor is also fulfilled as when the Junta army carries out these acts of appropriation of property stated above these acts are carried out by the army against the people of Burma under the order of the Junta as such these acts are committed by the soldiers of the junta as part of their duties. ${ }^{668}$ Based on the above analysis it can be said that in Burma the nexus between the crime committed and the armed conflict is established.

The fifth element of the war crime of pillage under the Rome Statute is that "The perpetrator was aware of the factual circumstances that established the existence of an armed conflict." ${ }^{669}$ With regards to this element it is clear that the Tatmadaw is aware that the Junta has assigned its soldiers the Tatmadaw to attack and destroy these opposition armed forces in Burma so as to ensure that the Junta is at the helm of the political situation and economic situation in Burma. ${ }^{670}$ As such it is arguable that this element is also fulfilled. Based on all the analysis and arguments above it can be concluded that the war crime of pillage is occurring in Burma. Article 8 (1) of the Rome Statute states that the ICC will have jurisdiction over war crimes when the crime is committed as a policy or plan or such crimes are committed at a large scale. ${ }^{671}$ In Burma the crime of plunder is committed at a large scale as illustrated above therefore the ICC will have jurisdiction over the war crime of plunder. ${ }^{672}$

\section{H The Contemporary Case Laws on Pillage}

In the case of $\mathrm{P} v$ Kunarac the Appeals Chamber had stated that war crimes are not stagnant. The Chamber stated $:{ }^{673}$

The determination of what constitutes a war crime is therefore dependant on the development of the laws and customs of war at the time when an act charged in an indictment was committed. As was once noted, the laws of war "are not static, but by continual adaptation follow the needs of a changing world."

\footnotetext{
${ }^{667}$ See HRC Resolution 5/1 above n 261, para 63,para 64

${ }^{668}$ See HRC Resolution 5/1 aboven 261, para 60, para75

${ }^{669}$ Rome Statute, above $\mathrm{n} 34$, art 8 (2) (e) (v)

${ }^{670}$ See HRC Resolution 5/1 above n 261, Para 64

${ }^{671}$ See Rome Statute above n 34, art 8 (1)

${ }^{672}$ See HRC Resolution 5/1, above n 261, para 64, para 65, para 66

${ }^{673}$ Prosecutor v Kunarac above n 326, Para 67
} 
In the light of this statement some contemporary cases dealing with the issue of plunder will be analyzed and the principles of these cases will be applied to the situation that is prevalent in Burma.

In the ICTY Trial Chamber of Prosecutor $v$ Mucic and Delic the defendants were charged under count 49 for the offence of plunder committed at the Celebici camp. ${ }^{674}$ The paraphrased indictment read "The plunder of money, watches and other valuable property belonging to persons detained at the Celebici camp between May and September 1992.",675

The Prosecution in this case tendered evidence that at the Celebici camp many of the prisoners had lost their personal items such as watches, jewellery such as rings and money to the perpetrators of this crime and as such the crime of Plunder was committed under Article 3 (e) of the Statute. ${ }^{676}$ The defence argued that the acts that the accused were alleged to have committed did not constitute a violation that was serious under international humanitarian law and flowing from this fact the Prosecution in this case did not possess the requisite subject matter jurisdiction over the alleged offence of plunder ${ }^{677}$ pertaining to Article 1 of the Statute which states that $:^{678}$

\begin{abstract}
The International Tribunal shall have the power to prosecute persons responsible for serious violations of international humanitarian law committed in the territory of the former Yugoslavia since 1991 in accordance with the provisions of the present statute.
\end{abstract}

The defence in making its argument relied on the Appeals Chamber Jurisdiction decision in Tadic which had stated that: ${ }^{679}$

\footnotetext{
${ }^{674}$ Prosecutor $v$ Mucic above n 539, para 28

${ }^{675}$ Ibid

676 Ibid

${ }^{677}$ Prosecutor v Mucic above n 539, para 1151.

${ }^{678}$ Prosecutor v Mucic above n 539 Para 1151. Also see Prosecutor v Tadic above n 577, para 94, Also see ICTY statute above $\mathrm{n} 7$, art 1

${ }^{679}$ See Prosecutor $v$ Tadic above n 577, para 94
} 
The violation must be "serious", that is to say it must constitute a breach of a rule protecting important values, and the breach must involve grave consequences for the victim. Thus, for instance the fact of a combatant simply appropriating a loaf of bread in an occupied village would not amount to a "serious" violation of international law" although it may be regarded as falling foul of the basic principle laid down in Article 46 paragraph 1 of the Hague Regulations (and the corresponding rule of customary international law) whereby private property must be respected by an army occupying an enemy territory.

The Trials Chamber in the Mucic case held that it agreed with the Tadic Appeals Chamber Jurisdiction decision that the violation under International Humanitarian law to be considered serious under the Article 1 of the Statute two elements has to be satisfied, the first element is that the crime committed must constitute "a breach of a rule protecting important values"680 and the second element is that it must involve "grave consequences to the victim." Chamber reasoned that the commission of the crime did involve "a breach of a rule protecting important values" 682 however since the value of the property appropriated were insignificant it did not constitute "grave consequences to the victim" ${ }^{683}$ As such the trial chamber dismissed count 49, and the accused Mucic and Delic were acquitted of the crime of plunder. ${ }^{684}$

Applying the ratio of this case to the situation in Burma the appropriation of property such as the land from the people ${ }^{685}$ would amount to a serious violation under International Humanitarian Law and it will fulfil the two elements in the Tadic case that is firstly it is "a breach of a rule protecting important values.",686 When the lands of the people are arbitrarily confiscated this would mean that the victims would lose their homes and their livelihood and the majority of the villagers in Burma are heavily dependent on their lands to make a living. ${ }^{687}$ This

\footnotetext{
${ }^{680}$ Prosecutor $v$ Mucic above n 539, para 1154

681 Ibid

682 Ibid

683 Ibid

684 Ibid

${ }^{685}$ HRC Resolution 5/1 above n 261, para 64

${ }^{686}$ See Prosecutor v Mucic above n 539, Para 1154

${ }^{687}$ See HRC Resolution 5/1, above n 261, para 64, para 63
} 
would mean that there are "grave consequences to the victim." ${ }^{\text {,68 }}$ As such it is arguable that in such a situation in Burma the war crime of plunder could be deemed to have been committed.

However when the soldiers of the Junta in Burma steals money and other valuables from the villagers ${ }^{689}$ this could amount to the crime of plunder if the two elements that were stated in the case of Tadic is satisfied. ${ }^{600}$ The appropriation of property constituting of money and other valuables would amount to "a breach of a rule protecting important values",691 however in regards to whether the second element is fulfilled this will depend on whether the properties that were stolen from the villagers had caused "grave consequences to the victim" ${ }^{\prime 62}$ The Tadic case which was followed by the Trials Chamber in the Mucic held that as the property that were appropriated were of insignificant value as such this did not amount to "grave consequences to the victim" 693 As such in the situation in Burma where the properties that were taken from the villagers, the value of the property would determine whether the second element is fulfilled, for instance if the properties taken by the soldiers involved huge sums of money this would amount to "grave consequences to the victim"694 as such the second element is fulfilled and the crime of plunder would have been committed. However if the properties that were taken were items of insignificant value such as old watches this would not constitute a "grave consequence to the victims",695 and as such the crime of plunder would be deemed not to have been committed.

In the Trials Chamber of Blaskic, the accused was charged for the crime of plunder of buildings, private businesses, private property, dwellings and livestock all of which belonged to the Bosnian Muslims. ${ }^{696}$ In ascertaining whether Blaskic

\footnotetext{
${ }^{688}$ See Prosecutor $v$ Mucic above n 539, para 1154

${ }^{689}$ See HRC Resolution 5/1 above n 261, para 65

${ }^{690}$ See HRC Resolution 5/1, above n 261, para 65. Also see Prosecutor v Mucic above n 539, para 1154.Also see Prosecutor $v$ Tadic, above n 577, para 94

${ }^{691}$ Prosecutor $v$ Mucic above n 539, para 1154

692 Ibid

693 Ibid

694 Ibid

695 Ibid

${ }^{696}$ See Prosecutor v Blaskic (IT-95-14-T)(Trial Chamber)(Judgment)( 3 March 2000 ) Para 14
} 
had committed the war crime of plunder the Trial Chamber made the following statement: ${ }^{697}$

The prohibition of the wanton appropriation of enemy public or private property extends to both isolated acts of plunder for private interest and to the organized seizure of property undertaken within the framework of a systematic economic exploitation of occupied territory. Plunder should be understood to embrace all forms of unlawful appropriation of property in armed conflict for which individual criminal responsibility attaches under international law, including those acts traditionally described as pillage.

The Trials Chamber found Blaskic guilty of the war crime of plunder. ${ }^{698}$ In the case of Blaskic the accused was charged for the destruction of inter alia dwellings and private property. ${ }^{699}$ This was a more obvious case of plunder as compared to the case of Mucic which involved the appropriation of private property of insignificant value. ${ }^{700}$

Applying the principles that Trials Chamber used to find Blaskic guilty to the situation in Burma it is arguable that in Burma when the soldiers of the Junta in Burma arbitrarily confiscates the land of the people $\mathrm{e}^{701}$ this would amount to plunder as these acts will amount to "unlawful appropriation of property.",702 Further since the arbitrary confiscation of land that happens in Burma are not isolated incidents but are rampant in many territories that is controlled by the Junta $^{703}$ one of the parties to the armed conflict in Burma as such this kind of large scale of appropriation of property would tantamount to plunder. ${ }^{704}$

${ }^{697}$ Prosecutor $v$ Blaskic above n 696, Para 184

${ }^{698}$ See Prosecutor $v$ Blaskic above $\mathrm{n}$ 696, the disposition of the court where Blaskic is found guilty of plunder

${ }^{699}$ Prosecutor v Blaskic above n 696, para 14

${ }^{700}$ See Prosecutor v Mucic above n 539, para 1154

${ }^{701}$ See HRC Resolution 5/1, above n 261, para 64

${ }^{702}$ Prosecutor $v$ Blaskic above n 696, para 184

${ }^{703}$ See HRC Resolution 5/1 above n 261, Para 64

${ }^{704}$ Prosecutor v Blaskic above n 696, para 184 
In the Appeals Chamber in Blaskic the verdict of guilt on the accused for the war crime of plunder was sustained. ${ }^{705}$ The Appeals Chamber in Prosecutor $v$ Blaskic had also stated that many Trial Chambers had also considered that when properties are destroyed this may tantamount to "Persecutions as a crime against humanity"706 In this respect the Appeals Chamber in Blaskic also discussed the case of Prosecutor v Kupreskic. ${ }^{707}$ In the case of Prosecutor v Kupreskic the Trial Chamber considered that the destruction of property could constitute persecution depending on the kind of property that was being destroyed. ${ }^{708}$ The criteria is that the property that is destroyed must effect the victim to a severe degree. ${ }^{709}$ As such if the destruction of property had effected the victim to a severe degree then the crime against humanity would have been committed however if the destruction of property did not effect the victim to a severe degree then even if the act of destruction of property was done on discriminatory grounds this would not amount to crime against humanity. ${ }^{710}$ In the case of Kupreskic the property that were destroyed were the homes of the people and the destruction of these homes was actually destroying the livelihood of a certain population and as such it had the same consequences that forced transfer or relocation as such the acts constituted a breach of fundamental human rights and if the acts was performed on discriminatory grounds this would amount to persecution. ${ }^{711}$

In Burma following the ratio in the case of Kupreskic it is arguable that when the arbitrary confiscation of land occurs the people are left without a home and lands and this actually does destroy the livelihood of the people in Burma as the majority of them rely on their lands for their livelihood, ${ }^{712}$ as such this will tantamount to a breach of basic human rights and since these acts are performed on discriminatory grounds as only the lands of the minorities who are also the enemies involved in the armed conflict in Junta such as such as the lands of the

\footnotetext{
${ }^{705}$ See Prosecutor v Blaskic (IT-95-14-A)(Appeal Chamber)(Judgment)(29 July 2004)

${ }^{706}$ Prosecutor v Blaskic above n 705, Para 146

${ }^{707}$ Ibid

708 Ibid

709 Ibid

710 Ibid

711 Ibid

712 See HRC Resolution 5/1, above n 261, para 63, para 64
} 
Shans are confiscated, ${ }^{713}$ as such it is arguable that the crime of persecution is taking place in Burma. However it is important to note that when pillage is employed to support the charge of persecution then it could be charged as a crime against humanity. ${ }^{714}$ However pillage by itself is a crime based on issues relating to property and therefore cannot be classified as a Crime Against Humanity. ${ }^{715}$

The International Criminal Justice case of Democratic Republic Of Congo v Uganda had stretched the ambit of the war crime of plunder to also include the exploitation of natural resources. ${ }^{716}$ In this case the ICJ had to decide whether the soldiers and officers of Uganda People's Defence Force (UPDF) had committed plunder, looting and exploitation on the natural resources in DRC. ${ }^{717}$ As such the court in this case had to consider the point as to whether the failure of Uganda to put a stop to the looting, plunder and exploitation of the natural resources in DRC by the soldiers and officers of UPDF would amount to Uganda breaching one of its international obligations. ${ }^{718}$

The DRC contended that "Uganda's actions was a violation of the "principle of DRC's sovereignty over its natural resources."719 The court noted that the principle of sovereignty of natural resources was a principle of Customary International Law and this principle could be found in the General Assembly Resolution 1803 (XVII) of 14 December 1962 , the contents of which was further explained in the Declaration on the Establishment of a New International Economic Order (General Assembly Resolution 3201(S.VI) of 1 May 1974) and the Charter of Economic Rights and Duties of States (General Assembly resolution 3281 (XXIX) of 12 December 1974). ${ }^{720}$ Although the court recognized

\footnotetext{
${ }^{713}$ See Voravit, above n 640

${ }^{714}$ See Michael Mcgregor "Regarding State Owned Resources or in the alternative, resources in which the state has the primary or superior interest-would exploitation of such resources constitute pillage as that term is defined in international criminal law? And would such a conduct be a crime against humanity as it is a state owned resource, or a resource in which the state has the primary or superior interest?" (Memorandum For The Office Of The Prosecutor Special Court Of Sierra Leone) 34

${ }^{715}$ Ibid

${ }^{716}$ See Democratic Republic Of the Congo (DRC) v Uganda (Judgment) (19 December 2005) (ICJ)

${ }_{717}^{71}$ DRC v Uganda above n 434 Para 234

${ }^{718} \mathrm{Ibid}$

${ }^{719}$ DRC v Uganda above n 716 Para 244

${ }^{720}$ Ibid
} 
that this was an important principle however the court could not uphold "the contention of the DRC that Uganda violated the principle of DRC's sovereignty over its natural resources". ${ }^{721}$ The reason for this was because this principle was not applicable to the situation in the present case where the looting, pillage and exploitation of natural resources is done by "members of the army of a State militarily intervening in another State." 722

In this case the court had considered that it has a ample evidence which was persuasive and credible which had led the court to come to the conclusion that that high ranking officers and soldiers of the UPDF were involved in the "looting, plundering and exploitation" of DRC's natural resources and that the military authority had failed to take any action to put an end to the looting, plundering and exploitation of the natural resources in DRC.$^{723}$

Based on the facts on this case the court reasoned that whenever the UPDF had committed the acts of looting, plunder and exploitation of the natural resources of the DRC this constituted a violation of jus bello which prohibits the commission of such acts by foreign armies in the territory in which it is present. ${ }^{724}$ The court further noted that in these kinds of situations regard should be given to Article 47 of the Hague Regulations of 1907 and Article 53 of the Fourth Geneva Convention of 1949 where by virtue of both these Articles pillage is prohibited. ${ }^{725}$

On the issue of plunder, looting and exploitation of natural resources of DRC by Uganda the Court held that the acts of looting, plunder and exploitation committed by the soldiers and officers of the DRC had led the court to come to the conclusion that Uganda was responsible for these acts as these unlawful acts were committed by members of the Uganda's armed forces. ${ }^{726}$ The Court stated that based on the evidence it was proved that Uganda had breached its obligations as an occupying power in the district of Ituri. ${ }^{727}$

\footnotetext{
721 Ibid

722 Ibid

${ }^{723}$ DRC v Uganda above n 716, Para 246

${ }^{724}$ DRC v Uganda above n 716, Para 245

${ }^{725}$ Ibid

${ }^{726}$ DRC v Uganda above n 716, Para 246

${ }^{727}$ DRC v Uganda above n 716, Para 249
} 
Uganda's argument that that the exploitation of the DRC's natural resources in DRC by the soldiers and officials of Uganda had benefited the local population of DRC was not accepted as there was lack of evidence to substantiate this explanation although the court noted that such an action was permitted under International Humanitarian Law. ${ }^{728}$

The Court concluded that Uganda had failed to comply with its international obligation under Article 43 of Hague Regulations of 1907 as an occupying power in Ituri. ${ }^{729}$ As such Uganda was internationally responsible for the acts of looting, plunder and exploitation of the natural resources of DRC committed by members of UPDF in the territory of DRC. ${ }^{730}$ The court further concluded that these acts committed by Uganda had resulted in the injury of the territory of DRC and to its people. $^{731}$ Accordingly Uganda had an obligation to make reparation. ${ }^{732}$

The case of DRC v Uganda is legally significant in three aspects. Firstly, this case stands for the proposition that when the natural resources of a state is illegally exploited by members of the army of a state military this could give rise to a breach of international obligation under Article 43 of Hague Regulations and as such the accused could be held for the crime of plunder. ${ }^{733}$

Secondly this case has widened the traditional scope of properties which were regarded under the law as subject to the act of plunder. The crime of plunder traditionally involved the appropriation of public and private properties. ${ }^{734}$ The industrialists at Nuremberg were convicted for the plunder of properties such as factories. $^{735}$ The ICTY case of Mucic involved the plunder of personal items such as money and watches, ${ }^{736}$ the case of Blaskic involved the plunder of inter alia dwellings and buildings. ${ }^{737}$ As such the case of DRC $v$ Uganda seems to move away from the traditional concept and ideas attached to the offence of

\footnotetext{
728 Ibid

${ }^{729}$ DRC v Uganda above n 716, Para 250

${ }^{730}$ Ibid

${ }^{731}$ DRC v Uganda above n 716,, para 259

${ }^{732}$ Ibid

${ }^{733}$ See DRC v Uganda above n 716, para 250

${ }^{734}$ See United Nations War Crimes Commission above n 73, 18,19

735 Ibid

${ }^{736}$ See Prosecutor v Mucic above n 539, Para 28

${ }^{737}$ See Prosecutor v Blaskic above n 696, Para 184
} 
plunder and states the proposition that even the natural resources of a country could be plundered.

Thirdly this case stands for proposition that a State's claims of the principle of sovereignty over it's natural resources will not be applicable when the members of the army of a state has militarily intervened in that state. ${ }^{738}$

In applying the principles of law in the case of DRC $v$ Uganda to the situation in Burma, it is clear that firstly there are some differences between the situation in both the countries. In DRC v Uganda it was the occupying military force of Uganda (UDBF) which were indicted and found guilty of plundering the natural resources in DRC. ${ }^{739}$ As such in relation to Burma the issue that arises is can a ruling government of a country the Junta be held to be liable for the crime of plunder for the exploitation of the country's natural resources. To answer this question the point that has to be clarified is that when the exploitation of state owned natural resources occurs is this a violation of the laws of war.

Hague IV states "pillage is prohibited" but provisions of Hague IV only applies to conflicts which are international in nature. ${ }^{740}$ The Geneva (IV) Conventions also applies only to international conflicts. ${ }^{741}$ Burma has ratified the IV Geneva Convention. ${ }^{742}$ Additional Protocol II of the IV Geneva Conventions and Common Article III apply to situations that are facing conflicts that are internal. ${ }^{743}$ Burma has not ratified Additional Protocol II of the IV Geneva Conventions. $^{744}$ Article 33 of Geneva IV states:- ${ }^{745}$

\footnotetext{
${ }^{738}$ See $D R C v$ Uganda above n 716, Para 244

${ }^{739}$ See DRC v Uganda above n 716, para 250

${ }^{740}$ See Convention (IV) respecting the laws and Customs of War on Land and its annex:Regulations concerning the Laws and Customs of War on the Land. The Hague, 1907 above $\mathrm{n} 184$

${ }^{741}$ See Convention (IV) relative to the Protection of Civilian Persons in Time of War.Geneva, 12 August 1949 ,above n 278

${ }^{742}$ See HRC Resolution 5/1, above n 216, para 52

${ }^{743}$ See Protocol Additional to the Geneva Conventions of 12 August 1949, and relating to the Protection of Victims of Non-International Armed Conflicts (Protocol II ) above n 556, Also see Convention (III) relative to the Treatment of Prisoners of War.Geneva, 12 August 1949 ${ }^{744}$ Ibid

${ }^{745}$ Geneva Convention (IV) above n 278, art 33
} 
The prohibition of pillage is applicable to the territory of a party to the conflict as well as to occupied territories. It guarantees all types of property, whether they belong to private persons or to communities or the state. On the other hand it leaves intact the right of requisition or seizure.

Where the issue of requisition is concerned it is a general rule that the occupying power must ensure that the needs of the civilian population is taken into account. ${ }^{76}$ Further Article 147 of the Geneva Conventions states that the "extensive appropriation of property not justified by military necessity is a grave breach of the Convention. ${ }^{, 747}$ Article 64 of Geneva Convention IV states that:- ${ }^{748}$

The Penal laws of the occupied territory shall remain in force, with the exception that they may be repealed or suspended by the occupying power in cases where they constitute a threat to its security or an obstacle to the application of the present convention

If Article 33 and 64 of the Geneva Convention IV are read together it would seem that maintaining the property rights and ensuring it is protected before the occupation, is one way of ensuring that the exploitation of state owned resources will not take place but it will be regulated. ${ }^{749}$

Applying the above provisions to the situation in Burma and to the issue of the natural resources in Burma it can be deduced that even if the natural resources is the property of the state of Burma but based on Article 33 of the Fourth Geneva Convention which Burma has ratified, pillage is prohibited and this prohibition extends to parties to the conflict. ${ }^{750}$ However Article 33 is silent on the act of requisition and seizure which means the Junta could requisition the

\footnotetext{
${ }^{746}$ Geneva Convention (IV) above n 278, art 55

747 Geneva Convention (IV) above n 278, art 147

${ }^{748}$ Geneva Convention (IV) above n 278, art 64

${ }^{749}$ See Michael Mcgregor above n 714, 20

${ }^{750}$ See Geneva Convention (IV) above n 278, art 33
} 
natural resources but this must be done in line with the general rule which requires that the needs of the civilian population is taken into account. ${ }^{751}$

When the Junta enters into Joint venture agreements with the TNCs for extraction of natural resources the Junta and the TNCs obtains monetary benefits however the Junta spends only a very minimal sum of its profits for the people which would mean that the needs of the civilian population are not met. ${ }^{752}$ It is also arguable that Burma has exploited its natural resources as the exploitation of the natural resources by the Junta far outweighs the needs of its people and the peoples' needs are not met. ${ }^{753}$ As such it is arguable that the Junta in Burma has breached Article 147 of the Geneva Convention as they have appropriated property that is not justified by military necessity.

A state that exploits the resources of another State could be guilty of pillage as in the case of DRC v Uganda the armed forces of Uganda exploited the natural resources of DRC. ${ }^{754}$ However the situation in Burma involves a State exploiting its own resources without any benefit to the great majority of the people in the State. ${ }^{755}$ The natural resources of a State rightfully belongs to the State and as such a State cannot commit plunder on what already belongs to the State. ${ }^{756}$ States are of course at liberty to use their natural resources in the way the State deems $\mathrm{fit}^{757}$ and generally countries rich in natural resources would ensure that her citizens enjoy the economic benefits of the resources as well. ${ }^{758}$ However what happens when a State has for many years enjoyed the yield of the natural resources whilst its citizens are in abject poverty which is the situation facing Burma today.

${ }^{751}$ See Geneva Convention (IV) above n 278, art 147

${ }^{752}$ See HRC Resolution 10/27, above n 3,para 102 .The Junta earned 3 billion dollars in 2009 as the revenue from natural gas and oil, yet the Junta only 0.5 percent of its Gross Domestic Product for the people of Burma

${ }^{753}$ Ibid

${ }^{754}$ See DRC v Uganda above n 716, Para 245.

${ }^{755}$ See HRC Resolution 5/1 above n 261, para 64.Also see HRC Resolution 10/27 above n 3, para 100, para 101.

${ }^{756}$ See UNGA Resolution 1803 (XVII) on Permanent Sovereignty Over Natural resources (14 December 1962)

${ }^{757}$ Ibid

${ }^{758}$ For instance in countries such as New Zealand and Malaysia which has natural resources, the government of both countries uses the resources for the benefit of the people. 
It is arguable that it is an emerging principle that even a State can be guilty of plunder, looting and exploitation of the State's own natural resources where a few conditions are satisfied. The first condition is that the State is reaping huge profits from the natural resources, ${ }^{759}$ secondly the great majority of the citizens of the State are living in dire need, poverty and where their basic needs such as safe dwelling places are not provided by the State ${ }^{760}$ and thirdly the great majority of the citizens of the State are subject to systematic violations of the law and human rights abuses. $^{761}$ In Burma all the above conditions is satisfied therefore it is arguable that on the basis of an emerging principle the Junta in Burma could be guilty of committing plunder, looting and exploitation of its natural resources.

\section{The Role Played By the Officials of Transnational Corporations in the War Crime of Plunder in Burma.}

Here the role of the TNCs and the officers of the TNCs will be looked at in relation to the three types of plunder that takes place in Burma. ${ }^{762}$ The TNCs and the Junta has been business partners for many years by virtue of the Joint Venture Agreements signed between the Junta and the TNCs such as the Yadana and Yetagun projects. ${ }^{763}$ In relation to this project when the Joint Ventures are signed, the routes for the projects will be identified and subsequent to this the lands in these areas are arbitrarily confiscated to enable the pipelines to be built and the project is underway. ${ }^{764}$ If it were not for the projects the Junta has with the TNCs many areas and lands in Burma will not be confiscated. ${ }^{765}$

\footnotetext{
${ }^{759}$ See HRC Resolution 10/27, above n 3, para 102

${ }^{760}$ See HRC Resolution 10/27, above n 3, para 61, para 100, para 101

${ }^{761}$ See HRC resolution $10 / 27$, above n 3,para 121

${ }_{762}^{7}$ For the three types of plunder see HRC Resolution 5/1 above n 261, para 64, para 65, para 66.

${ }^{763}$ See HRC Resolution 10/27 above n 3, para 111. For instance Total has been doing business with the Junta in relation to the Yadana project since 1992. The Yadana project was one the first and biggest projects in which the TNCs and Junta collaborated in which had saved the Junta from bankruptcy .

${ }^{764}$ See Report on HRC Resolution 10/27 above n 3 para 111. Also see HRC Resolution 5/1 above n 261, para 64.

${ }^{765}$ See HRC Resolution 5/1 above n 261, para 66
} 
When the Junta and TNCs signs project deals and the project sites are identified the areas of the project sites are immediately militarized. ${ }^{766}$ The influx of soldiers in the land is followed by many human rights abuses that is carried out by the military which includes demanding money and other valuables from the villagers. $^{767}$

Due to the Joint Venture projects that the Junta signs with the TNCs especially in relation to the extraction of natural resources this has enabled the Junta to exploit the natural resources in Burma. ${ }^{768}$ The requisition of the Junta of the natural resources in Burma in collaboration of the TNCs is out of all proportion against the economic needs of its people whose need are not met even at the most marginal level. ${ }^{769}$ Furthermore the incomes generated from these joint ventures are used by the Junta for its internal warfare efforts. ${ }^{770}$ The upkeep of the Junta army the Tatmadaw takes million of dollars and the Tatmadaw is used by the Junta to fight the other armed groups in Burma and to carry out the culture of impunity that is prevalent in Burma which has been recorded in numerous reports by the United Nations. ${ }^{771}$ The officials of TNCs are the willing partners of the Junta which has enabled the Junta to steadily carry out the exploitation of the natural resources for many years in Burma. ${ }^{772}$

\section{J An Analysis of the Complicity of the Industrialists in Relation to the War Crime of Plunder.}

In the activities of IG Farben in Poland some of the officials of this conglomerate were found to be guilty of being complicit in the war crime of

\footnotetext{
${ }^{766}$ See HRC Resolution 10/27, above n3, para 112

${ }^{767}$ See HRC Resolution 10/27 above n 3,para 112. Also see HRC Resolution 5/1 above n 261, Para 65

${ }^{768}$ See Report on HRC Resolution 10/27, above n 3, Para 111

${ }^{769}$ See HRC Resolution 10/27, above n 3, para 100, para 101, para102. See For instance in 2009 the Junta earned 3 billion dollars from its gas and oil sales but it spends a paltry $0.5 \%$ of its Gross Domestic Product on health .

${ }^{770}$ HRC Resolution 10/27, above n3, para 98.

${ }^{771}$ See HRC resolution 10/27 above n3, Para 112, Also See HRC Resolution 5/1 above n 261, Para 65

${ }^{772}$ See HRC Resolution 10/27, above n 3, para 112.The TNCs have been doing business with the Junta in Burma for almost two decades
} 
plunder. ${ }^{773}$ The complicity of the officials of IG Farben was ascertained as firstly the officials played an active role in unlawfully acquiring factories and shares in the territories invaded by Germany such as in Poland and France. ${ }^{774}$ Secondly after the Third Reich had confiscated private and public properties the officials of IG Farben proceeded to obtain permanent titles to the properties that were confiscated. ${ }^{775}$ Thirdly the officials of Farben also took part in negotiations with private owners to acquire either controlling or substantial interests in the properties although the consent by the owners was not given on a voluntary basis. ${ }^{776}$ This was because at the time the officials of Farben were in the midst of negotiations with the private owners the power of the military was an obvious threat which guaranteed that the interests of the officials of Farben always prevailed in all these negotiations which resulted in Farben becoming extremely wealthy. $^{777}$

The complicity of the officials of Farben was defined in Nuremberg based on the actions of the officials of Farben in the war crime of plunder. ${ }^{778}$ In Poland the officials of IG Farben had firstly planned and engineered the act of plunder. ${ }^{779}$ Secondly they had ensured that they obtained the support of the Third Reich for the act of plunder that was to be committed. ${ }^{780}$ Thirdly they had proceeded to carry out the act of plunder in the guise that it was done formally by arranging the conference and giving itself the title of Trustee to the properties it had intended to plunder. ${ }^{781}$ Fourthly the officials of Farben bought over Boruta ${ }^{782}$ and fifth these officials obtained all the equipments that were in the plant facilities at Wola and Winnica. ${ }^{783}$ The tribunal in holding some of the officials of Farben

\footnotetext{
${ }^{773}$ See United states Of America v Carl Krauch And Twenty Two Others above n 37, 1140

${ }^{774}$ Ibid

${ }^{775} \mathrm{Ibid}$

${ }^{776} \mathrm{Ibid}$

777 Ibid

${ }^{778}$ See United Nations War Crimes Commission, Trials Of War Criminals IG Farben and Krupp, above $\mathrm{n} 73,19$

${ }^{779}$ Ibid

${ }^{780}$ Ibid

${ }^{781}$ Ibid

${ }^{782}$ See United Nations War Crimes Commission Trials Of War Criminals IG Farben and Krupp above $\mathrm{n} 73,20$

${ }^{783}$ Ibid
} 
complicit in the war crime of plunder stated that the actions taken by the Reich ministry was under the instigation of Farben. ${ }^{784}$

The industrialists such as the officials Farben were directly complicit with the Third Reich in the war crime of plunder which had propelled the judges at Nuremberg to declare that indeed Farben on its own had committed the war crime of plunder and the initiative for the crime originated from IG Farben. ${ }^{785}$

\section{K An Analysis of the Complicity of the Officials of TNCs in Burma in Relation to the War Crime of Plunder.}

In Burma the officials of TNCs may not be directly complicit for the war crime of plunder but it is arguable that they are indirectly complicit or silently complicit. The indirect or silent complicity of the TNCs in Burma can be deduced as the TNCs in Burma have become business partners with the Junta for years. ${ }^{786}$ Major TNCs such as Total have been in business alliance with the Junta for the exploration of natural resources since the late $20^{\text {th }}$ century. ${ }^{787}$ At the beginning of their business venture Total had given major loans to the Junta in furtherance of the business ventures. ${ }^{788}$ The willing partnerships by TNCs has enabled the Junta in Burma to commit systematic exploitation of the natural resources in Burma which benefits the Junta and foreign TNCs but has resulted in effects which are detrimental to the people. ${ }^{789}$

In response to the criticisms some of the TNCs received for being in active business dealings with the Junta, major TNCs in Burma such as Total has reasoned that their business ventures in Burma has increased job opportunities and as a whole they have contributed positively to the economy of Burma. ${ }^{790}$ However in reality the business deals between the TNCs in Burma has benefitted

\footnotetext{
${ }^{784}$ United States Of America v Carl Krauch And Twenty Two Others above n 37, 1140

785 Ibid

786 See Tyler R. Gianni Destructive Engagement : A Decade Of Foreign Investment In Burma in an Issue Paper of earthRights International's Burma Project, (1999) 3

${ }^{787}$ Ibid. For instance Total became involved in the Yadana pipeline in 1992.

${ }^{788}$ Total had made loans to the Junta before the exploration of the Yadana pipeline took place. See Philip Swanson above n 600 ,26

${ }^{789}$ See Report on HRC Resolution 5/1 above n 261, Para 66

${ }^{790}$ See Total “Total In Myanmar, A Sustained Commitment” (2008) 42
} 
only the TNCs and the Junta as $75 \%$ of the people in Burma are involved in the agricultural sectors and derive their income from agriculture. ${ }^{791}$

\title{
L An Analysis of the Actus Reus and Mens Rea Requirement of Aiding and Abetting of the Industrialists in Nuremberg in Relation to the War Crime of Plunder.
}

At Nuremberg the tribunal in stating the Actus Reus and Mens Rea requirement for the war crime of plunder had stated that: ${ }^{792}$

\begin{abstract}
No individual defendant may be held guilty of the war crimes or any aspect thereof, charged under count two, unless the competent proof establishes beyond reasonable doubt that he knowingly participated in an act of plunder or spoliation because he was either (a) a principal or (b) an accessory to the commission of any such crime or ordered or abetted the same or (c ) took a consenting part therein or (d) was connected with plans or enterprises involving its commission or (e) was a member of an organization or group connected with the commission of any such crime.
\end{abstract}

From the above statement actus reus required for the war crime of plunder would be that the person must have 'Participated in an act of plunder or spoliation. ${ }^{793}$ Those who had participated in the crime encompasses a very wide categories of persons. ${ }^{794}$ This will include those who participated as a principal, an accessory, someone who ordered the crime, or abetted. ${ }^{795}$ This category of persons is also inclusive of those who were a part of the crime by way of consent and it also covers individuals who were connected with plans and enterprises involving the act of plunder and it also covers people who were members of organizations or groups who were connected in the commission of such crimes. ${ }^{796}$

\footnotetext{
${ }^{791}$ See International Confederation Of Free Trade Unions (ICFTU) Doing Business In or With Burma (prepared for the International Confederation of Free Trade Unions (ICFTU) 200527. Also See HRC Resolution 5/1 above n 261, Para 63

${ }^{792}$ United States Of America v Carl Krauch And Twenty Two Others above n 37, 1137

${ }^{793}$ Ibid

${ }^{794}$ Ibid

${ }^{795} \mathrm{Ibid}$

${ }^{796}$ Ibid
} 
To fulfil the actus reus of the crime here the person could be liable by doing the act of a principal, accessory or abetting the crime but even if the individual had in some way consented or was connected or was a member of an organization that carried out the crime of plunder the person would have fulfilled the actus reus of the crime. ${ }^{797}$ The mens rea requirement is knowledge that is the individual must have known about the crime of plunder that was being committed. ${ }^{798}$

\section{Has the Officials of TNCs satisfied the Actus Reus and Mens Rea Requirement of Aiding and Abetting the War Crime of Plunder under International Criminal Law?}

The ICTY case of $R V$ Furundgiza states that the acts that would suffice as the actus reus for aiding and abetting would be practical assistance, moral support or encouragement. ${ }^{799}$ The mens rea required for an individual to become an aider and abettor is knowledge. ${ }^{800}$

On the issue of the actus reus required of an aider and abettor and on the point of practical assistance the case of Hechingen Deportation is relevant. ${ }^{801}$ This case involved five persons who were charged for being complicit in the act that involved the mass deportation of Jews in 1941 and $1942 .{ }^{802}$ One of the accused who was working in the administrative section and whose job function involved the organizing of the executions based on the orders he had received from the Gestapo. ${ }^{803}$ The Tribunal held this accused was guilty of aiding and abetting the Gestapo in the commission of its criminal offence. ${ }^{804}$ The accused objected by saying that his conduct had in no way contributed to the crimes because if he had not performed his duties an easy replacement would have taken place and some one else would have to act in compliance with the decrees

\footnotetext{
${ }^{797}$ Ibid

${ }^{798}$ Ibid

799 Prosecutor v Furundzija above n 493, Para 235

${ }^{800}$ Prosecutor v Furundzija above n 493, Para 245

${ }^{801}$ See case of Hechingen Deportation case summary in Prosecutor v Furundzija, above n 493, para 224

${ }_{802}$ Ibid

${ }^{803} \mathrm{Ibid}$

${ }^{804}$ Ibid
} 
of the Gestapo. ${ }^{805}$ The court stated that the guilt of an aider and abettor would not be negated just because the job that he was doing could have been easily undertaken by another. ${ }^{806}$

By signing business deals with the Junta the officials of TNCs are assisting the Junta in the commission of war crime of plunder. ${ }^{807}$ Employing the principle laid down in the case of Hechingen Deportation to the situation of the officials of TNCs in Burma, even if some officials of the TNCs contend that if they do not invest in Burma due to the public scrutiny and criticism there will be many other TNCs that will take their place in reaping the benefits of doing business in Burma, this will not absolve the guilt of the officials of certain of the officials of TNCs that are doing business with the Junta in Burma. ${ }^{808}$ This is because the guilt attached to the officials of TNCs as aider and abettor will not be influenced by whether there were many other TNCs that would have ventured in business with Burma, as this will not be a material consideration on the issue of aider and abettor liability. ${ }^{809}$

In the case of Synagogue the court held that the accused was guilty for the devastation of a synagogue although he had not physically taken part in the destruction of the synagogue neither did he take part in the plan of destructing the synagogue. ${ }^{810}$ Despite this he was found guilty for the Crime Against Humanity because his powerful presence at the scene of the crime and coupled with his knowledge of the criminal activities was enough to convict him. ${ }^{811}$ The Synagogue case which was decided by the German Supreme Court stands for the proposition that a person may be liable as an aider and abettor not only through practical assistance or encouragement but merely through moral support when the person who is a spectator that is witnessing the crime is held in such respect by the perpetrator so that his presence encourages their conduct, when this happens

\footnotetext{
805 Ibid

806 Ibid

${ }^{807}$ See HRC Resolution 10/27, above n 3, para 111

${ }^{808}$ See Hechingen case in Prosecutor v Furundzija above n 493, para 224

${ }^{809}$ Ibid

${ }^{810}$ See Synagogue case in Prosecutor v Furundzija above n 493 , Para 205

811 Ibid
} 
the spectator may be guilty as an aider and abettor for that crime. ${ }^{812}$ Further in the ICTR case of Akayesu the accused was a mayor of the place where the crime was being committed. ${ }^{813} \mathrm{He}$ was found guilty as an aider and abettor of the crime as he was a person in authority at the scene of the crime who encouraged the criminal acts by his presence at the scene. ${ }^{814}$

Employing the principle found in these two cases to the situation in Burma it is arguable that the association and the presence of multi billion dollar TNCs and at certain times their officials in Burma can be said to be giving moral support to the Junta.It is arguable that the Junta regards the presence of the major TNCs and their officials as an encouragement to the various crimes committed by the Junta including the crime of plunder. As such in this respect it is arguable that the officials of these famous TNCs are aiding and abetting the Junta in the crime of plunder.

As such in relation to the officials of the TNCs in Burma it can be argued that they have satisfied the test laid down in the case of Prosecutor $v$ Furundjiza for the actus reus required for aiding and abetting. By signing business deals with the Junta they are assisting the Junta in the commission of war crime of plunder. ${ }^{815}$ Further the mere presence of multi billion dollar TNCs and their officials in Burma do lend moral support to the Junta to continue in the commission of various crimes in Burma including the war crime of plunder.

The next issue that has to be considered is whether the practical assistance, moral support and encouragement of the TNCs and officials of the TNCs has led to the substantial effect of the crime of plunder being committed in Burma. ${ }^{816}$ In the Bruno Tesch case which is also famously known as the Zyklon B case the three accused Bruno Tesch, Joachim Droshin and Karl Weinbacher were all charged for war crimes as they had supplied poison gas which was used in the killing of the allied prisoners in the concentration camps and the accused had knowledge that

\footnotetext{
812 Ibid

${ }^{813}$ See Prosecutor $v$ Akayesu above n 426, para 209

814 Ibid

${ }^{815}$ See HRC Resolution 10/27, above n 3, para 111

${ }^{816}$ See the test laid down in Prosecutor v Furundzija above n 493, para 249
} 
the gas was to be used for such a purpose. ${ }^{817}$ This case that was decided was very significant as:- ${ }^{818}$

The decision of the Military Court in the present case is a clear example of the application of the rule that the provisions of the laws and customs of war are addressed not only to combatants and to members of state and other public authorities, but to anybody who is in a position to assist in their violation. The activities with which the accused in the present case were charged were commercial transactions conducted by civilians. The Military Court acted on the principle that any civilian who is an accessory to a violation of the laws and customs of war is himself also liable as' a war criminal.

In this case the Prosecution had argued that the accused had with the requisite knowledge supplied commodity to certain parts of the state and the state was using this commodity for the mass killing of civilians who belonged to the allied forces. ${ }^{819}$ The three accused in this case were charged for war crimes as they were alleged to have violated Article 46 of the Hague Regulation of $1907 .{ }^{820}$ The Prosecution had declared that the act of the accused amounted to a war crime and the accused were war criminals because they were "putting the means to commit the crime into the hands of those who actually carried it out." $\$ 21$

The Judge Advocate in this case had stated that concerning the case the court has to be certain of three facts that is firstly the citizens of the allied nations were killed by the Zyklon B gas, secondly it was Tesch and Stabenow who had supplied this gas and thirdly the accused had knowledge that the gas was being used to kill humans. ${ }^{822}$ At the conclusion of the case Bruno Tesch and Weinbacher were sentenced to death. ${ }^{823}$ However Joachim Droshin was found not guilty due to his subordinate position in the firm and as such he was not in a position to ensure or prevent the zyklon B gas from being transported to Auschwitz or to

\footnotetext{
${ }^{817}$ See United Nations War Crimes Commission, Law Reports Of Trials Of War Criminals Zyklon B Case, 93

${ }^{818}$ United Nations War Crimes Commission above n 817, 103

${ }^{819}$ United Nations War Crimes Commission above n 817,94

820 Ibid

821 Ibid

${ }^{822}$ United Nations War Crimes Commission above n 817,101

${ }^{823}$ United Nations War Crimes Commission above n 817,102
} 
altogether stop the gas from being used in Auschwitz. ${ }^{824}$ In this case the Prosecution in his closing argument stated that the accused with knowledge that murders were going to take place supplied the commodity to the State which led to the substantial effect of the crime that is the Zyklon B gas was ultimately used to kill the allied civilians. ${ }^{825}$

By applying the principle of this case to the situation in Burma, it is arguable that the officials of TNCs by engaging in continued business deals with the Junta for many years are giving practical assistance and moral support and encouragement to the Junta and this assistance and moral support has a substantial effect on the commission of the war crime of plunder by the Junta.

In the case of Bruno Tesch the court had found the Defendants guilty not because they sold the commodity known as Zyklon B but because they had sold it to the SS who were using it to kill allied civilians. ${ }^{826}$ In the situation in Burma it is the argument of this author that the officials of TNCs are doing what corporations do that is enter into business ventures in various countries however when TNCs do business in Burma in the extraction of natural resources the effect is that the war crime of plunder takes place in Burma, ${ }^{827}$ the plunder that takes place is the arbitrary confiscation of the lands and exploitation of natural resources and pillage of the belongings of the villagers in Burma. ${ }^{828}$

The income that the Junta obtains from its business with the TNCs amounts to billions of dollars and this money is used by the Junta to fight its internal war in Burma, and for the upkeep of its army the Tatmadaw to fight its internal warfare and the needs of the people are met at a very marginal level and at times not met at all. $^{829}$

\footnotetext{
${ }^{824}$ Ibid

${ }^{825}$ See United Nations War Crimes Commission above n 817,101

${ }^{826}$ Ibid

${ }^{827}$ See HRC Resolution 10/27, above n 3, para111, para 112

${ }^{828}$ See HRC Resolution 5/1 above $\mathrm{n}$ 261, para 64, para65, para 66.

${ }^{829}$ See HRC Resolution 10/27 above $\mathrm{n} 3$, para 98, para 100, para 101.Despite earning 4.8 billion from the Yadana project since 2000, The Junta spends only $0.5 \%$ of its Gross Domestic Product on health
} 
The mens rea element that needs to be satisfied for an aider and abettor under International Criminal Law is knowledge. ${ }^{830}$ In relation to the mens rea requirement of an aider and abettor the court in Prosecutor $v$ Furundjiza stated that: ${ }^{831}$

Therefore, it is not necessary for an aider and abettor to meet all the requirements of mens rea for a principal perpetrator. In particular, it is not necessary that he shares and identifies with the principal's criminal will and purpose, provided that his own conduct was with knowledge. That conduct may in itself be perfectly lawful; it becomes criminal only when combined with the principal's unlawful conduct. Reference should also be made to article 30 of the Rome Statute, which provides that, unless otherwise provided, a person shall be criminally responsible and liable for punishment for a crime within the jurisdiction of the Court only if the material elements are committed with intent and knowledge.

In the Zyklon B case the Prosecution did not attempt to prove that the Defendant Tresch and Weinbacher had acted with the intention of assisting in the killing of the allied civilians. ${ }^{832}$ The purpose of the defendant was to sell the insecticide for profit. ${ }^{83}$ The charge as accepted by the court was that the defendants had knowledge what the buyer that is the SS intended to do with the Zyklon B gas they were supplying. ${ }^{834}$

Therefore in the case of Burma the mens rea is satisfied as although the purpose of the officials of TNC in doing business in Burma is to generate business and profit which is lawful however the officials of TNCs have knowledge that the party that they are engaging in business with, the Junta intends to use the profits they have obtained through their business dealings with the TNCs to commit the war crime of plunder in Burma which includes systematic

\footnotetext{
${ }^{830}$ See Prosecutor v Furundzija above n 493 , para 249

${ }^{831}$ Prosecutor v Furundjiza above n 493, para 243, para 244

${ }^{832}$ United Nations War Crimes Commission above n 817,94

${ }^{833}$ United Nations War Crimes Cmmission above n 817, 101

${ }^{834}$ United Nations War Crimes Commission above n 817,94
} 
exploitation of the economy of the country with detrimental effects to the people of the country ${ }^{835}$

\section{N Conclusion}

Based on the above analysis and arguments it can be concluded that a non international armed conflict is still occurring in Burma. ${ }^{836}$ Further the officials in TNCs in Burma could be liable for being complicit in the war crime of plunder of private properties. On the issue of plunder or exploitation of natural resources it is arguable that this is an emerging principle that is a state can commit plunder and exploit the natural resources of the country when a great number of its citizens are suffering and are subject to human rights abuses and violations of the law. ${ }^{837}$ Therefore on the basis of an emerging principle as discussed here and above the officials of TNCs could be complicit in the crime of plunder of natural resources.

\section{O The Members of the Corporate Board of TNCs that Should be Prosecuted for being Complicit in the War crime of Plunder and for Crimes Against Humanity of Enslavement}

In the case of Bruno Tesch, at the conclusion of the trial Joachim Droshin was found not guilty due to his subordinate position in the firm as he had no power to influence the outcome of the events in relation to the zyklon B gas. ${ }^{838}$

Employing this principle to the situation involving the officials of TNCs and the war crime of plunder in Burma, the officials of TNCs that should be prosecuted for the war crime of plunder would be those officials who are the important decision makers in the TNCs, who would have propelled and agreed that the TNCs enter into joint venture projects in Burma for the extraction of natural resources. ${ }^{839}$ The members of the corporate board that should be prosecuted for the war crime of plunder in Burma in relation to the Yadana project will include the CEO's and the board of directors of Chevron, Total and PTTETT

\footnotetext{
${ }^{835}$ HRC Resolution 5/1 above n 261,para 64

${ }^{836}$ HRC Resolution 10/27, above n 3, Para 66

${ }^{837}$ See HRC Resolution 10/27, above n 3, para 101, para 121

${ }^{838}$ United Nations War Crimes Commission, above n 817,102

${ }^{839}$ See Total Oil : Fuelling the oppression in Burma www.birmaniademocratica.org (accessed 12 July 2010)
} 
and other officials of TNCs who are important decision makers. ${ }^{840}$ Their prosecution is necessary and justified as these individuals are responsible to influence certain policies and determine the turn of events in relation to the war crime of plunder in Burma that is occurring in Burma. ${ }^{841}$

In the case of Farben, the officials of Farben who had shown "positive conduct" in relation to the war crime of plunder by "ordering, approving and authorizing" the act of plunder were held to be guilty of the crime. ${ }^{842}$ Officials such as Ter Meer and Von Schnitzler were held to be guilty of plunder because they possessed knowledge about the way the properties were taken from the lawful owners and they had taken positive action in the negotiation. ${ }^{843}$ Individuals such as Von Knieriem was acquitted of the crime of plunder as he had no knowledge about the methods used by Farben to obtain properties from their owners. $^{844}$

In Burma officials of TNCs such as Chevron, Total and PTTETT who displayed "positive conduct" in relation to the crime of plunder could also be prosecuted for the crime that is if they had committed the following acts firstly if they had an in depth knowledge of the circumstances surrounding the projects and had actively negotiated with the Junta to secure these projects in the extractive industries. Secondly officials that advised on the negotiations that took place between the Junta and TNCs which finally enabled the TNCs to secure the projects. Thirdly officials who had special knowledge in relation to these projects and who attended the important meetings in relation to these projects. Fourthly officials of TNCs who had signed the joint venture agreements with the Junta. Officials of TNCs who did not engage in any of these acts, and who had not engaged in any positive conduct in relation to the plunder and who had no positive knowledge of the crime of plunder being committed in Burma should not

\footnotetext{
${ }^{840}$ See Total oil:Fuelling the oppression in Burma www.birmaniademocratica.org (accessed 12 July 2010)

${ }^{841}$ See Getting it Wrong: Flaws “ Corporate Social Responsibility” and Misrepresentations Surrounding Total and Chevron's Yadana Gas pipeline in Military-Ruled Burma (Myanmar) www.earthrights.org (accessed 12 July 2010)

${ }^{842}$ For instance see United Nations War Crimes Commission above n 73, 18,19

${ }^{843}$ United States Of America $v$ Carl Krauch And Twenty Two Others above n 37,1156,1159-1160

${ }^{844}$ United States Of America v Carl Krauch And Twenty Two Others above n 37, 1159
} 
be prosecuted for the crime of plunder. The CEOs, directors and officials of the three TNCs stated above can be prosecuted for being complicit in the war crime of plunder under the Rome Statute by the International Criminal Court. ${ }^{845}$

In the case of Farben officials such as Carl Krauch and Ambros were found guilty for being complicit in the crime of slave labour as they had engaged in "positive conduct" in relation to the crime of slave labour. ${ }^{846}$ Carl Krauch was involved in the allocation of camp inmates and Ambros went to Auschwitz twice a year to obtain information about the construction of the project. ${ }^{847}$ In the case of Flick, Weiss and Flick were found guilty as they had taken constructive steps to procure prisoners. ${ }^{848}$

In relation to the crime of slave labour in Burma, firstly, the CEOs and Board Of Directors of Chevron, Total and PTTETT should be prosecuted for being complicit in the crime against humanity of slave labour. ${ }^{849}$ The CEO's and Board Of directors of these TNCs have the power and are in the position to influence certain policies such as TNCs should refrain from working together with States that are well known for using forced labour vastly in the country. ${ }^{850}$

Other officials from these three TNCs that could also be prosecuted for the crime against humanity of slave labour would be the officials of TNCs who engage in "positive conduct" in relation to the crime of slave labour. Positive conduct by officials of TNCs will encompass the following acts done by the officials of TNCs. Firstly if these officials had requested the Junta for security to guard the pipelines knowing well that requesting the Junta for security will entail forced labour and other human rights abuses, ${ }^{851}$ secondly officials who act as managers in Projects sites where slave labours are used could be prosecuted for the crime. Thirdly officials of TNCs who may be indirectly involved in the

\footnotetext{
${ }^{845}$ Rome Statute above n 34, art 25

${ }^{846}$ United States Of America v Carl Krauch And Twenty Two Others above n 37,1187,1193

${ }^{847}$ Ibid

${ }^{848}$ United States Of America v Friedrich Flick And Five Others above n 223, 1202

${ }^{849}$ See Total Oil: Fuelling the oppression in Burma www.birmaniademocratica.org (accessed 12 July 2010) Also See Getting It Wrong: Flaws "Corporate Social Responsibility" and Misrepresentations Surrounding Total and Chevron's Yadana Gas pipeline in Military-Ruled Burma (Myanmar)www.earthrights.org(accessed 12 July 2010)

${ }^{850}$ Ibid

${ }^{851}$ See HRC Resolution 10/27 above n 3,Para 112
} 
procurement, allocation and recruitment of slave labours could be prosecuted for the crime. Officials that have no knowledge about the use of forced labour and who work with the TNCs should not be prosecuted for the crime against humanity of slave labour. The CEOs, directors and the officials involved in the acts stated above can be indicted for the crime of enslavement under the Rome Statute of the International Criminal Court. ${ }^{852}$

\footnotetext{
${ }^{852}$ Rome Statute above n 34, art 25
} 
The previous chapter showed that officials of TNCs could be liable under International Criminal Law for war crimes and crimes against humanity. In this chapter a few aspects of TNCs to which these officials are attached to will be analyzed such as the power wielded by TNCs today, TNCs as subjects of international law and the soft laws that govern TNCs today and the effectiveness of these soft laws. The primary purpose of this chapter is to show that at present prosecuting TNCs involves various problems due to the separate legal personality of TNCs and due to the corporate structure of TNCs. Further it will be shown that suing TNCs at the host state, home states and under the ATCA are also besieged with problems. At the end of the chapter some recommendations are made in relation to the future prosecution of TNCs

\section{A Transnational Corporations In The Global Arena}

TNCs can be defined as "an enterprise comprising entities in more than one country which operate under a system of decision-making that permits coherent policies and a common strategy." ${ }^{853}$ TNCs operating in some countries has resulted in these TNCs contributing positively to the economy of the country. ${ }^{854}$ However some TNCs have also been alleged to be complicit in international crimes where the TNCs partner with repressive regimes such as Unacol in Burma and Shell in Nigeria. ${ }^{855}$

The report produced by the Institute of Policy Studies in 2000 revealed that out of the 100 largest economies that dominate the world, 51 of these are corporations. $^{856}$ The World Investment Report of 2009 revealed there is an

\footnotetext{
${ }^{853}$ See United Nations Conference On Trade And Development www.unctad.org (accessed 29 April 2009)

${ }^{854}$ Investment.Impact of TNC www.oaklandpl.org (accessed 12 July 2010)

${ }^{855}$ See Wiwa v Shell The case against Shell http://wiwavshell.org (accessed 14 April 2009) Unacol and Shell were sued under the Alien Tort Claims Act and both corporate defendants paid huge sums of settlement to the Plaintiffs and never proceeded to Trial

${ }^{856}$ Sarah Anderson and John Cavanagh "Top 200: The Rise Of Corporate Global Power" (2000)
} 
estimated 82,000 TNCs and 810000 subsidiaries of TNCs in the world. ${ }^{857}$ Many of these corporations have bigger economies then certain countries for instance Venezuela's economy is smaller than that of Royal Dutch Shell. ${ }^{858}$ These statistics mean that in some countries TNCs hold more power than the states. ${ }^{859}$ In Burma the Junta's earnings from the extractive industries which is done in collaboration with TNCs totalled 3 billion in $2009 .{ }^{860}$ The power wielded by these corporations has even led to Transnational Criminal Organisations (TCO) ${ }^{861}$ which indicates that there is a need for transnational corporations to be governed by an international legal framework. ${ }^{862}$

TNCs are economically strong as evidenced by the statement in UNCTAD World Investment Prospects Survey 2007-2009 which states that despite there being some concerns regarding the instability of global finances, the foreign direct investment by TNCs are expected to be on the rise for the period spanning the next three years. ${ }^{863}$

\section{B Transnational Corporations as Subjects under International Law}

TNCs as global market players have drawn the attention of jurists and much debate has taken place in recent years as to the status of TNCs under international law. ${ }^{864}$ The proposition that TNCs are subjects under international law is supported by the fact that TNC's obligations are stipulated under certain International Treaties. ${ }^{865}$ The United Nations Convention on the Law of The Sea

${ }^{857}$ World Investment Report 2009 www.unctad.org/wir (accessed 12 April 2010)

${ }^{858}$ See Sarah Anderson and John Cavanagh above n 856

${ }^{859}$ Suzanne Elston "Global Economy Shifting The Balance Of Power" (2001)

${ }^{860}$ See Report on HRC Resolution 10/27 above n3, para 102.

${ }^{861}$ See Transnational Organized Crime www.g7.utoronto.ca (accessed 11 April 2010)

${ }^{862}$ See Natalya S. Pak, James P. Nussbaumer "Beyond Impunity : Strengthening the Legal Accountability of Transnational Corporations for Human Rights Abuses" Working papers no.45, (2009)

${ }^{863}$ UNCTAD.org. Press Expansion Of Fdi Flows Through 2009 www.unctad.org/ (accessed 20 March 2009)

${ }^{864}$ See Peter T.Muchlinski “Human Rights And Multinationals Is Is There A Problem? ”(2001) 77 Int'IL Affairs 31, 45

${ }^{865}$ For instance see United Nations Conventions on the Law Of the Sea (10 December 1982) 1833

UNTS 3. (The Convention entered into force on 16 November 1994) 
1982 places restrictions on the appropriation of sea beds. ${ }^{866}$ This prohibition of appropriation extends to not only states and natural persons but also to legal persons. ${ }^{867}$ Further Article 1 of The Convention on Civil Liability for Oil Pollution Damage 1969 states that any owner of the ships will be liable for the pollution that is caused by the ship. ${ }^{868}$ For purposes of Article 1 of the said Convention the owners of ships are not limited to natural persons but includes legal persons. $^{869}$ Article 10 of the United Nations Convention against Transnational Organized Crime of 2000 makes explicit reference to the liability of legal persons. ${ }^{870}$ Article 10 subsection 1 of the said Convention states that liability can be criminal, civil or administrative. ${ }^{871}$ In relation to Convention against Transnational Organized Crime it is clear that on reading the Articles contained therein that there is no direct obligation imposed on the TNCs but the direct imposition is on the states to ensure that the States take the necessary steps to ensure that TNCs act in accordance with the Articles of the said Convention. ${ }^{872}$ However the Articles contained in the Convention proves that under International Conventions TNCs are regarded as subjects under International Law that can commit crimes. ${ }^{873}$

The role that TNCs play in the international field is further evidenced by their involvement in major international agreements. ${ }^{874}$ For instance the role played by TNCs in internationally recognized rights and disputes such as in the Agreement on Trade Related Aspects of Intellectual Property Rights (TRIPS) is

\footnotetext{
866 Ibid

${ }^{867}$ United Nations Convention on the Law Of the Sea above n 865, art 305 (f)

${ }^{868}$ Convention On Civil Liability for Oil Pollution Damage, 1969 (adopted on 29 November 1969, entered into force 19 June 1975) art 1

${ }^{869}$ Convention On Civil Liability for Oil Pollution Damage, 1969 above n 868, art 1 includes individual or partnership or any public or private body whether corporate or not

${ }^{870}$ United Nations Conventions Against Transnational Organized Crime 2000 (opened for signature 12-15 December 2000 , entered into force 29 September 2003 )

871 See United Nations Convention Against Transnational Organized 2000 above n 870 , art 10 (1)

${ }^{872}$ United Nations Convention Against Transnational Organized Crime above n 870, art 5,6,8,23

873 Ibid

${ }^{874}$ See Vandana Shiva, B.K. Keayla TNCs The Real Architects of TRIPS (New Delhi , 1995)
} 
clear. ${ }^{875}$ Further TNCs are significantly involved in many phases of the World Trade Organization (WTO) proceedings which involves settlements of disputes. ${ }^{876}$

In the ICJ case of Reparations For Injuries Suffered In The Service Of The United Nations ${ }^{877}$ the United Nations General Assembly had invoked the International Court Of Justice (ICJ) for an advisory opinion in relation two points. ${ }^{878}$ Firstly in the situation where one of the members of United Nations had suffered injuries which had involved state responsibility whether the United Nations as an Organization possess the capacity to bring an international claim against the de jure or de facto government in connection to the damages caused to the United Nations or to victims or persons entitled through him. ${ }^{879}$ Secondly if the first question is answered affirmatively how would the action of the United Nations be reconciled with the rights of the state of which the victim is a national. $^{880}$

To answer these questions the ICJ had to determine the issue as to whether $\mathrm{UN}$ as an organization possessed international personality. ${ }^{881}$ In determining this issue the ICJ reasoned that the UN was a political body and it had duties under certain International Conventions for instance under the Convention on the Privileges and Immunities of the UN of $1946 .{ }^{882}$ This convention creates rights and duties between each of the signatories and the UN. ${ }^{883}$ The ICJ held that such conventions could only function on the basis that the parties to the convention possessed international personality and UN had enjoyed and exercised certain functions and rights and the enjoyment of these functions and rights would not happen unless UN the organization had a international personality and exercised it on an international plane. ${ }^{884}$ The ICJ concluded in its opinion that the UN was an

\footnotetext{
${ }^{875}$ Ibid

${ }^{876}$ See CEO Observer Issue 4-WTO Millenium Bug:TNC Control Over Global Trade Politics http://archive.corporateeurope.org/wto (accessed 14 April 2010)

${ }^{877}$ See Reparation For Injuries Suffered In The Service Of The United Nations (Advisory Opinion) (1949) ICJ

${ }^{878}$ Reparation For Injuries Suffered In The Service Of The United Nations above n 877,121

${ }^{879}$ See Reparation For Injuries Suffered In the Service Of The United Nations above n 877,121

${ }^{880}$ Reparation For Injuries Suffered In the Service Of The United Nations above n 877,121

${ }^{881}$ Reparation For Injuries Suffered In The Service Of The United Nations aboven 877,178

${ }^{882}$ Reparation For Injuries Suffered In the Service Of The United Nations above n 877, 179

${ }^{883}$ Ibid

${ }^{884}$ Ibid
} 
international person although it is not a state or a "super state." ${ }^{\text {" }} 85$ Since its an international person it is a subject of international law and capable of possessing international rights and duties and as such it could bring international claims. ${ }^{886}$

Based on the ratio of the UN reparation case, it is arguable that although the degree of international legal personality possessed by the UN and TNCs are not on the same plane as the organization of the UN is created by the treaties involving nations of the world and TNCs are business entities in various countries. ${ }^{887}$ However it can be said that the Reparations case opened the prospect that organisations have international legal personality and this principle may well extend to the biggest and most powerful TNCs.

\section{The Regulation of Transnational Corporations}

In the past decades due to the growing influence of TNCs in the economic fields and their expanding role as global players a few soft laws were created with the aim of regulating the conduct of TNCs. ${ }^{888}$ Some of these soft laws include the International Labour Organization Tripartite Declaration of Principles concerning Multinational Enterprises and Social Policy, Organization for Economic Cooperation and Development (OECD) guidelines, United Nations Global Compact and United Nations Norms. ${ }^{889}$ These soft laws which seek to regulate TNCs has not been successful in its aims to deter TNCs from being complicit in the commission of certain crimes. ${ }^{890}$ This is due to the fact that these soft laws are

\footnotetext{
885 Ibid

886 Ibid

${ }^{887}$ See History of the United Nations www.un.org/aboutun/unhistory (accessed 12 July 2010)Also See United Nations Conference On Trade And Development www.unctad.org (accessed 29 April 2009)

${ }^{888}$ United Nations norms is one of the softlaws that was created to regulate TNCs. For a discussion on the United Nations Norms, see Carolin F. Hillemanns "UN norms on the Responsibilities of Transnational Corporations And Other Bussiness Enterprises with regard to Human Rights" (2003) 10 Ger LJ 1

${ }^{889}$ Alice de Jonge "Expanding the Limits Of Corporate Responsibility: An Institutional Approach”(2008) Monash Business Review

${ }^{890}$ For instance even after these soft laws were put into effect, yet Shell committed crimes in Nigeria and Total and Chevron are also still operating in Burma and contributing to human rights
} 
not legally binding on the TNCs which gives an option to the TNCs not to adhere to them. ${ }^{891}$ As these soft laws are based on the principle of voluntariness the TNCs that contravenes these soft laws face no legal repercussions and on the whole it can be said that the soft laws are ineffective mechanisms to effectively regulate TNCs. ${ }^{892}$

\section{Can Transnational Corporations be Liable for Human Rights Abuses and International Crimes?}

John Ruggie the United Nations' Secretary-General's Special Representative expresses the view that it is the state that bears the responsibilities in relation to human rights issues. ${ }^{893}$ In the said report on the issue of Corporate Responsibilities and International Crimes he notes that states should exercise extraterritorial jurisdiction over their corporations that are engaged in business abroad. ${ }^{894}$ On the issue of corporate responsibilities for other human rights violations he stated that at present there was insufficient evidence to establish direct responsibility on corporations under customary international law. ${ }^{895}$ Antonio Cassese has observed that since States for various reasons has not given TNCs an international standing therefore corporations possess neither international rights nor duties. ${ }^{896}$ Where the protection and promotion of human rights is concerned Peter T. Muchlinski has stated that it is the state that bears the responsibilities and the responsibility of corporations on these issues is secondary as it is unlikely that TNCs would knowingly breach such rights. ${ }^{897}$ However he

abuses. See Wiwa v Shell The case against Shell http://wiwavshell.org/the-case-against-shell (accessed 14 April 2009)

${ }^{891}$ See Marion Weschka Human Rights And Multinational Enterprises: How can Multinational Enterprises Be Held Responsible for Human Rights Violations Committed Abroad?660

${ }^{892}$ Advisory Council Of Jurists Reference "Human Rights And Corporate Accountability" (APF Conference Paper, 2008) 6

${ }^{893}$ See John Gerard Ruggie “Business And Human Rights The Evolving International Agenda” (A working paper of the Corporate Social Responsibility Initiative, 2007) 13

${ }^{894}$ John Gerard Ruggie above n 893,17

895 John Gerard Ruggie above n 893,19

${ }^{896}$ Antonio Cassese , “International Law In A Divided World”, (1986) 103

${ }^{897}$ Peter T.Muchlinski “Human rights And Multinational Is There A Problem?” (2001) 77 Int'IL Affairs 31,45 
qualifies this statement by stating that where in extreme situations Multinational Enterprises (MNE) is directly involved with the host state for fundamental violations of human rights then the law should develop to ensure that both the State and the MNE should share the responsibilities for such violations. ${ }^{898}$ In the context of the International Criminal Court Andrew Clapham argues that if it is admitted that international human rights law and international humanitarian law imposes duties and rights on natural persons, then it has to be admitted that legal persons also have international legal personality that enables them to enjoy some of these rights therefore it follows that legal persons can be prosecuted. ${ }^{899}$

\section{E The research by Fafo and the Prosecution of Corporations for} International Crimes by Home States

In 2006 a Norwegian Research Institute known as Fafo Institute for Applied International Studies published a study known as Commerce, Crime and Conflict (CCC). ${ }^{900}$ The purpose of the study was to ascertain whether in countries either than the United States there was in fact any existing legal framework which could ensure that economic actors could be made accountable for aiding and abetting international crimes and human rights violations. ${ }^{901}$ The CCC survey found that indeed it has been the prevalent practice in countries such as Australia, Belgium, Canada, France, India, Japan, the Netherlands, Norway, South Africa, the United Kingdom and the United States where criminal liability is applied to legal persons. ${ }^{902}$ The jurisprudence currently found in countries such as Argentina, Germany, Indonesia, Spain, and Ukraine shows that these countries do not recognize criminal liability that is applied to legal persons as a "conceptual matter." 903 In Indonesia and Argentina the national legislature has had very little regard to conceptual issues and these countries have adopted certain statutes

\footnotetext{
${ }^{898}$ Ibid

${ }^{899}$ Andrew Clapham "The Question Of Jurisdiction Under International Criminal Law Over Legal Persons: Lessons From the Rome conference on an International Criminal Court' in M.Kamminga and S. Zia-Zarifi, Liability Of Multinationals Corporations under international law (2000) 139,190

${ }^{900}$ See Anita Ramasastry "Mapping The Web Of Liability : The Expanding Geography Of Corporate Accountability in Domestic Jurisdictions" (2008) 2

${ }^{901}$ Ibid

${ }^{902} \mathrm{Ibid}$

${ }^{903}$ Ibid
} 
which imputes liability to legal persons for important crimes such as environmental crimes, commercial crimes and terrorism. ${ }^{904}$ The research done by Fafo is significant as it proves that various countries with various legal systems has indeed "expanded criminal laws to include legal persons." ${ }^{905}$ The research further shows that "many statutes specify how and when intent will be attributed to the business entity." 906

The research done clearly indicates that corporations could be prosecuted for ordinary crimes. ${ }^{907}$ Furthermore the research also showed the emergence of laws in various countries where crimes found under the Rome Statute were incorporated into "their domestic jurisprudence" 908 When statutes incorporate international criminal law into their domestic jurisdictions it becomes possible for corporations to be prosecuted for international crimes. ${ }^{909}$ The CCC survey by Fafo found that countries such as Argentina, Australia, Belgium, Canada, Germany, Netherlands, South Africa, Spain and United Kingdom have "fully incorporated" the three crimes found in the Rome Statute that is genocide, crimes against humanity and war crimes into their "domestic jurisprudence." 910 The CCC study has made important revelations that is in many jurisdictions legal persons (businesses) are generally held liable for breaches of International Criminal Law within domestic legal systems. ${ }^{911}$ The research done by Fafo to date remains a concept and not reality as until today a prosecutor has yet to prosecute a corporation for breaches of International Criminal law. ${ }^{912}$ Never the less the survey done by Fafo proves that many countries have recognized the importance of imputing criminal liability to corporations. ${ }^{913}$

\footnotetext{
${ }^{904}$ Ibid

${ }^{905}$ Ibid

${ }^{906} \mathrm{Ibid}$

${ }^{907}$ Ibid

${ }^{908}$ Anita above $\mathrm{n} 900,3$

${ }^{909}$ Ibid

${ }^{910}$ Ibid

911 Ibid

${ }^{912}$ Ibid

${ }^{913}$ See Anita Ramasastry, above n 900,2
} 


\section{F The Problems Involved in Suing TNCs}

To date TNCs has been sued in various jurisdictions. ${ }^{914}$ However the suing of TNCs under the present laws are by no mean straight forward. Some of the intricacies and difficulties involved in suing TNCs are discussed below.

\section{G Legal Personality of TNCs}

TNCs are made up of a group of companies and TNCs as a group of companies lack status as a legal entity. ${ }^{915}$ However if the corporate veil of TNCs is pierced it will be seen that TNCs are made up of many different corporations and each of these corporations is a legal entity. ${ }^{916}$ Each of these legal entity will be subject to the jurisdiction of the state in which it is situated. ${ }^{917}$

Every individual corporation which is a part of the TNC enjoys a distinct and separate legal personality from the others such as managers, shareholders and directors of companies who are also a part of the company. ${ }^{918}$ Companies also enjoy the status of being a limited liability company. ${ }^{919}$ This structure guarantees that the interests of managers and investors are protected, and the personal assets of the company is secured. ${ }^{920}$ In the $21^{\text {st }}$ century TNCs operate in many parts of the world and their subsidiary companies are an invaluable tool of the TNCs as these subsidiaries join forces with other companies and very often obtain substantial profits which are raked in and enjoyed by the parent TNCs. ${ }^{921}$

\footnotetext{
914 See Peter Muchlinski “Corporations In International Litigation:Problems of Jurisdiction And The United Kingdom asbestos cases”(2001) 50 Int'l Com LQ,1 . Also See Meike Westerkamp "International Conference on Transnational Corporations and Human Rights In Berlin" (2008) ECC Newsletter

915 The Concept Of International Legal Personality: An inquiry into the History and Theory of International Law http://goliath.ecnext.com (accessed 14 April 2010)

${ }_{916}$ Richard Meeran "Liability Of Multinational Corporations: A Critical Stage” 1

${ }^{917}$ Olivier De Schutter "Extraterritorial Jurisdiction As a Tool for improving the Human Rights Accountability of Transnational Corporations" (background paper to the seminar organized in collaboration with the office of the UN High Commissioner For Human Rights) 35

918 Advisory Council Of Jurists Reference above n 892,8

${ }^{919}$ Advisory Council Of Jurists reference above n 892,9

920 Ibid

${ }^{921}$ See Lucy Kronforst “Transnational Corporations And Human Rights Violations: Focus On Colombia”23 Wisconsin Int LJ321,329
} 
Subsidiaries of TNCs which have a limited liability very often handle operations that are highly risky. ${ }^{922}$ By employing this method the TNCs ensure that the assets of parent companies are secure and protected. ${ }^{923}$ In many situations the subsidiary companies do not even have enough capital, a situation which is often engineered by parent TNCs to ensure that the assets of parent companies remain untouched. ${ }^{924}$ To ensure that the Plaintiffs recover damages the Plaintiffs have often tried to prosecute parent companies as prosecuting the subsidiary would mean that damages in the form of monetary compensation is not attainable as many of these subsidiaries are limited liability companies and have limited finances or are insolvent. ${ }^{925}$

To counter the argument of separate legal entity which are often raised by parent companies when they are the subjects of litigation, prosecutors for the Plaintiffs have attempted in some cases to secure the liability of parent companies as illustrated in the cases below.

\section{H Piercing the Corporate Veil}

This concept of "piercing the corporate veil" which is known and recognized by the commercial world states the principle that every limited liability company is a separate legal entity and therefore a parent company cannot be held legally responsible for an unlawful act done by its subsidiary. ${ }^{926}$ However under certain circumstances the corporate veil has been successfully pierced firstly when it has been proven that the control of the parent company over the subsidiary was of such a magnitude that it was clear that the subsidiary company did not have any will of its own or could not exist on its own. ${ }^{927}$ Secondly the court will pierce the corporate veil to show that the subsidiary had no power and it was merely an instrument under the power of the parent company.

\footnotetext{
${ }^{922}$ See Peter Muchlinski above n 914, 17

${ }^{923}$ See Lucy Kronforst above n 921, 329

924 Ibid

${ }^{925}$ See Waldemar Braul, Paul Wilson "Parent Corporation Liability For Foreign Subsidiaries"1-7

${ }^{926}$ See Richard Meeran above n 916, 1

${ }^{927}$ See Olivier De Schutter above n 917,37
} 
${ }^{928}$ Thirdly if it can be proved that the subsidiary was in fact acting as an agent of the parent company. ${ }^{929}$ If this is proved then the acts of the subsidiary company will be seen as the acts of the parent company. ${ }^{930}$

The issue of control by the parent company over its subsidiary was raised by the Plaintiffs in the Bhopal case. ${ }^{931}$ This case involved the subsidiary of the United States TNC, The Union Carbide Of India Limited (UCIL) that had operations in Bhopal, India. ${ }^{932}$ The disaster at Bhopal occurred when a large quantity of methyl isocyanine was leaked from a pesticide plant which seeped into a densely populated city in Bhopal which resulted in the deaths of 2,000 people and 200,000 more were injured and many permanently disabled. ${ }^{933}$ In this case the Plaintiffs sought to prove that the parent company UCC was negligent as the original design of the plant which made provision for large amount of gas for storage had led to the disaster at Bhopal. ${ }^{934}$ The district judge however found that the participation by the parent company was limited and UCC's involvement was terminated long before the incident. ${ }^{935}$ UCC also argued that it should not be responsible for the disaster at Bhopal because the Indian subsidiary, (UCIL) was a separate legal entity and it did not have strong ties to the parent company in United States. ${ }^{936}$ On the other hand the Plaintiffs argued that the parent company owned and controlled the subsidiary and therefore the court should pierce the corporate veil and find that the parent company was liable for the claims made by the Plaintiffs. ${ }^{937}$ The Supreme Court dismissed the Plaintiffs case on the grounds of forum non conveniens and public policy. ${ }^{938}$ At the end UCC made a settlement

\footnotetext{
928 Olivier De Schutter above n 917,39

${ }_{929}$ Olivier De Schutter above n 917,37

${ }^{930}$ Ibid

931 Appellees v Union Carbide Corporation 809 F.2d 195 Also see In reunion Carbide Corp. Gas

Plant Disaster at Bhopal http://www.uniset.ca (accessed 12 February 2010)

932 Ibid

933 Ibid

934 Ibid

935 Ibid

936 Ibid

937 Ibid

938 Ibid
} 
of 350 million dollars to the Plaintiffs whereas the original claim was for 250 billion dollars. ${ }^{939}$

The Amoco Cadiz Oil Spill case illustrates the point of integrated enterprise. ${ }^{940}$ In this case the tanker known as Amoco Cadiz was broken by the storm which resulted in the spill of 220,000 tones of oil into the coast of France affecting important fisheries and tourist areas in France. ${ }^{941}$ In this case the court used the theory of integrated enterprise and held that the proximity of control by the parent company over its subsidiaries enabled the court to hold the parent company liable for the acts of the subsidiary. ${ }^{942}$ In this case the court held that the parent company could be liable for the acts of the subsidiary where it can be proved that the proximity of control of the parent over its subsidiaries was so high that the acts of the subsidiaries can be construed as the acts of the parent company. ${ }^{943}$ If this is proved then the theory of the legal separation of entities could be defeated. ${ }^{944}$

The legal significance of the Bhopal case is that parent companies of TNCs have attempted to escape or counter their liability by relying on private international law concepts such as forum non conveniens. ${ }^{945}$ Further the judicial system based in the territory of the home state of the TNC can dispose of cases that involves the lives of people on policy grounds. ${ }^{946}$

\section{Extraterritorial Jurisdiction and TNCs}

"Extraterritorial Jurisdiction occurs when a State seeks to influence the conduct of persons, acts or property outside its national territory." ${ }^{947}$ Here some issues with regards to Extraterritorial Jurisdiction and TNCs will be analyzed.

\footnotetext{
939 Ibid

${ }^{940}$ In the matter of Oil Spill by the Amoco Cadiz off the coast 954 F.2d 1279 (Seventh Circuit 1992) Also See Olivier De Schutter above n 917, 40

941 Ibid

942 Ibid

943 Ibid

944 Ibid

945 See Appellees v Union Carbide above n 931.

946 Ibid

${ }^{947}$ Olivier DeSchutter above n 917, 8
} 


\section{$1 \quad$ The types of extraterritorial jurisdiction}

International Law recognizes three types of extraterritorial jurisdiction that is prescriptive extraterritorial jurisdiction which refers to a state regulating persons or activities which is outside its territory, adjudicative extraterritorial jurisdiction refers to when another nations law is applied by a national court. ${ }^{948}$ Enforcement extraterritorial jurisdiction is wider then the previous two types of extraterritorial jurisdiction as this occurs when a state puts its organs into effect overseas. $^{949}$

The case of S.S Lotus involved issues relating to jurisdiction. ${ }^{950}$ In this case a collusion had occurred in the high seas between S.S Lotus 'the French mail steamer' which was on its way to Istanbul and the S.S Boz-Kourt the Turkish collier. ${ }^{951}$ The Boz-Kourt was badly damaged and eight Turkish nationals aboard it died and ten other Turkish nationals were saved. ${ }^{952}$ Subsequent to this the authorities in Turkey arrested Lieutenant Demons the officer on board of Lotus and the captain of the Boz-Kourt who had survived the incident. ${ }^{953}$ The issue that the Permanent Court of International Justice (PCIJ) had to decide was whether Turkey in exercising its jurisdiction over the officer of S.S.Lotus who was a French national had contravened the principle of international law. ${ }^{954}$ The case of Lotus made a distinction between enforcement extraterritorial jurisdiction and prescriptive and adjudicative extraterritorial jurisdictions in deciding the case although the exact terms were not used in the judgment. ${ }^{955}$ On the issue of enforcement of extraterritorial jurisdiction the court stated that a state cannot exercise the enforcement of extraterritorial jurisdiction outside its territory except if the rule relied on to exercise the enforcement of extraterritorial jurisdiction is

\footnotetext{
${ }^{948}$ See Olivier Deschutter above n 917, 25

949 Ibid

${ }^{950}$ The Case Of S.S. Lotus (France v Turkey) (Judgment) 1927 PCIJ Also see Olivier Deschutter above n 516,25

951 Ibid

952 Ibid

953 Ibid

954 Ibid

955 Ibid
} 
taken from an international custom or from a convention. ${ }^{956}$ On the other hand the court found that where prescriptive or adjudicative extraterritorial jurisdiction is concerned a state is at liberty to apply it as it deems fit. The court stated that: ${ }^{957}$

Far from laying down a general prohibition to the effect that States may not extend the application of their laws and the jurisdiction of their courts to persons, properties and acts outside their territory, it leaves them in this respect a wide measure of discretion, which is only limited in certain cases by prohibitive rules; every State remains free to adopt the principles which it regards as best and most suitable.

In the Lotus case the court stated that the Defendant had committed an act of negligence and the effects of this act was felt by the Boz-Kourt. ${ }^{958}$ Therefore both parties to the action should be able to have jurisdiction over the incident of the collision as such in this case there was "concurrent jurisdiction"959 Finally it was ruled that Turkey had not contravened the principles of international law in relation Article 15 of the Convention of Lausanne of July 24 1923, when Turkey began criminal proceedings against Lieutenant Demons. ${ }^{960}$ This case is significant to the extent that it supports the proposition that a state is at liberty to exercise extraterritorial jurisdiction if the nature of the extraterritorial jurisdiction is prescriptive or adjudicative however if the extraterritorial jurisdiction that needs to be exercised is in the form of enforcement then the qualification to this is that the said enforcement of extraterritorial jurisdiction must be emanating from a rule that is based on an international custom or convention. ${ }^{961}$

$2 \quad$ Suing of Transnational Corporations by home states

When home states sues TNCs this would require extraterritorial jurisdictions. $^{962} 90 \%$ of TNCs parent companies are located in developed

\footnotetext{
956 Ibid

${ }^{957}$ Olivier Deschutter above n 917,26

${ }^{958}$ The case Of S.S.Lotus above $\mathrm{n} 950,25$

959 Ibid

960 Ibid

${ }^{961}$ See Olivier Deschutter above n 917, 25, 26

962 See Surya Deva "Acting Extraterritorially to tame Multinational Corporations for Human Rights Violations:Who Should Bell The Cat?” (2004) MelbJIntLaw,5
} 
countries. ${ }^{963}$ Case precedents illustrates that the suing TNCs by home states are by no means straight as is illustrated in the case of Connelly v R.T.Z Corporation Plc and others. ${ }^{964}$ In this case the Appellant Connelly was employed by Rossing Uranium Ltd (R.U.L) in Namibia which is a subsidiary of R.T.Z. Corporation Plc (RTZ) which is an English company with the registered office in London. ${ }^{965}$ For a period of almost five years the appellant was employed by RUL which handled the business of mining uranium in Namibia. ${ }^{966}$ In 1986 the appellant was diagnosed with cancer of the larynx and the claim of the appellant was that the cancer was a result of inhaling silica uranium and its radioactive decay products which was found at the mine. ${ }^{967}$ Here the direct liability of the parent company was an issue as the parent company played a role in the defining of the policies of the subsidiary company. ${ }^{968}$

In this case the Respondent had tried to stay the action on the ground of forum non conveniens. ${ }^{969}$ Based on the evidence before the House of Lords it held that the proper forum to hear the case will be in England where the parent company is based and not in Namibia. ${ }^{970}$

\section{The problems of using extraterritorial jurisdiction on TNCs}

The concept of extraterritorial jurisdiction over TNCs is beset with problems and is not a simple method of enforcing liability on TNCs. ${ }^{971}$ The first concern is establishing the nationality of a TNC. ${ }^{972}$ The Barcelona Traction Light

\footnotetext{
963 See United Nations Conference On Trade And Development, The Universe Of The Largest Transnational Corporations, Geneva (2007)

${ }^{964}$ See House Of Lords-Connelly (A.P) v R.T.Z Corporation Plc and Others http://www.parliament.the -stationery-office .co.uk (accessed 11 April 2010)

965 Ibid

966 Ibid

967 Ibid

968 Ibid

969 Ibid

970 Ibid

${ }^{971}$ See Greg Flyn, Robert O’ Brien “ An International Western Labour Response To The Globalization of India And China” (2010) Global Law J 191,193

972 Olivier Deschutter above n 917,29
} 
And Power Company Limited case involved issues of nationality and TNCs. ${ }^{973}$ The case involved three states that is Canada, Spain and Belgium. ${ }^{974}$ In 1911 Barcelona Traction had incorporated its company in Canada. ${ }^{975}$ A few subsidiaries were created with some of its registered offices located in Spain and Canada, the Belgian government stated that a few years after world war one most of the shareholders in the company were Belgian nationals a fact that the Spain government stated was never proven. ${ }^{976}$ The Belgian Government alleged that various organs of the Spanish state had conducted itself contrary to international law towards the company, as such the Belgian government requested for reparation for the alleged damages caused to the Belgian shareholders. ${ }^{977}$ The court denied the claim by the Belgian government, the court stated that no jus standi was produced before the court and further an injury on the rights of the company which resulted in the injury of shareholders interest was not a sufficient ground for a claim as International law did not provide such a right on the shareholders national state. ${ }^{978}$

Second this concept presupposes that the host state that is the state from which the TNC is operating ${ }^{979}$ from and the home state which refers to the state the parent company is situated in, ${ }^{980}$ are not involved in the international crimes and that the necessary cooperation will be given by them. ${ }^{981}$ Burma is a good example which illustrates that not all countries would exercise its duties to prosecute TNCs as the host state itself might be the perpetrators of the international crimes and the host state might be working in partnership with the TNCs that is arguably complicit in the commission of the crimes. ${ }^{982}$ As such in situations such as this the host state will not prosecute the TNC. ${ }^{983}$ Thirdly this

\footnotetext{
${ }^{973}$ See The Barcelona Traction Light And Power Company Limited (Judgment)(1970) IC Para 824 974 Ibid

975 The Barcelona Traction Light And Power above n 973 ,Para 8-24 of Judgment

976 Ibid

977 The Barcelona Traction Light And Power above n 973, Paras 1-7,Para 26-31

978 The Barcelona Traction Light And Power above n 973,Para 32-101

${ }^{979}$ Philip Blumberg The Multinational Challenge To Corporation Law: The Search for a new corporate personality (1993) 169

980 Ibid

981 Surya Deva above n 962, 6

982 See HRC Resolution 10/27, above n 3, para 13

983 Ibid
} 
concept of extraterritorial jurisdiction may be construed by some states as an infringement of their sovereignty and this could pave the way for a strained relationship between the states. ${ }^{984}$ Fourthly it is possible that TNCs may try to stop their activities in that jurisdiction if they knew that they will be prosecuted by the host state. ${ }^{985}$ This will result in the investments in that state being lessened and the commercial activity in that state being substantially lessened. ${ }^{986}$ Fifth the enforcement that is legal will require that evidence is collected. ${ }^{987}$ Further compiling evidence to prove the case may also be difficult as this will depend on factors such as the relationships between the nations involved and will also depend on the willingness of the witnesses and victims to participate in the whole process. ${ }^{988}$ Sixth problems will arise in the process of prosecution ${ }^{989}$ for instance a host state may want to prosecute a corporation that is operating in its territory or the host state may want to prosecute a foreign corporation or a corporation that is part of a multinational group which is led by a parent corporation abroad. ${ }^{990}$ It is not possible to extradite legal persons. ${ }^{991}$ As such a corporation may go unpunished for the crimes it has committed although the TNCs liability under criminal law can be engaged by the host state and even where the state where the corporation has committed offences wants to prosecute the TNCs. ${ }^{992}$ The sanctions that are imposed by the state will require the home state's cooperation. ${ }^{993}$ For instance if the punishment pronounced on the TNC involves financial penalties, this will mean that there will be a seizure of the assets of the corporation and if the assets present on the territory of host state is insufficient to meet the financial penalties then a judicial winding up order will be required from the state in which the company is incorporated.$^{994}$

\footnotetext{
${ }^{984}$ Greg Flynn,Robert O’Brien above n 971, 193

985 Ibid

986 Ibid

987 Ibid

988 Ibid

${ }^{989}$ Olivier DeSchutter above n 917,31

990 Ibid

${ }^{991}$ See Olivier De Schutter above n 917, 17

992 Ibid

${ }^{993}$ See Olivier DeSchutter above n 917,18

994 Ibid
} 


\section{J Suing of TNCs by the Host state.}

If the TNCs in the host state breaches any law and violates human rights it is the duty of the host state to prosecute these TNCs. ${ }^{995}$ However there are various reasons as to why the host state may be unwilling to prosecute TNCs. ${ }^{996}$ Firstly it is also often the case where TNCs operate in countries (the host states) and these host states are developing countries where there is weak governance and the transparency of the judicial system is questionable. ${ }^{997}$ Burma is one such country where systematic violations of the law occur in the country, as such suing TNCs will not take place in countries such as Burma as the principal perpetrators of the crimes are the host state themselves. ${ }^{998}$ A further reason as to why a host state may not want to prosecute the TNC is because of their interest in the said projects for instance in Burma the state government in Burma are one of the partners in the joint venture projects where MOGE the company that is controlled by the state government in Burma has a sizeable stake in all the joint ventures projects undertaken with the collaboration of TNCs. ${ }^{999}$ As such no court in Burma would prosecute a TNC in Burma as the suing TNCs in the courts in Burma would have a detrimental effect to the state government who are business partners of the TNCs. ${ }^{1000}$

\section{K The Alien Tort Claims Act}

The notable perpetrators which has been indicted under the Alien Tort Claims Act includes various TNCs. ${ }^{1001}$ The Alien Tort Claims Act (ATCA) of

\footnotetext{
995 Surya Deva above n 962,6

${ }^{996}$ Foe example in Burma the Junta are the main pepertrators of the crime, and the judiciary is under the control of the Junta. As such prosecution of TNCs in Burma is unlikely. See HRC Resolution 10/27 above n 3, para 13.

${ }^{997}$ See Lucy Kronforst above n 921,33.Burma is also a country with weak governance, where there is lack of transparency and the Judicial system is not independent. See HRC Resolution 5/1 above n 261, para 40,41

998 The Junta in Burma are the principal perpetrators of the crimes such as Forced Labour. See HRC Resolution 10/27, above n 3, para 111

${ }^{999}$ MOGE the company controlled by the Junta enjoys a huge share of the profits garnered by the collaboration of business between the Junta and TNCs . The Junta earns massive income from these joint ventures. See HRC Resoltion 10/27 above n 3, para 102

${ }^{1000}$ The courts in Burma also lacks independence and will not give decisions that are contrary to the interest of the Junta. See HRC Resolution 10/27 above n 3, para 35

${ }^{1001}$ For instance Transnational Corporations such as Shell and Unacol were sued under the ATCA.
} 
1789 grants power and jurisdiction to the Federal Court in the United States to proceed with "any civil action by an alien for a tort only, committed in violation of the law of nations"1002

\section{$1 \quad$ Doe v Unacol}

This case which was heard by the ninth circuit court involved the villagers in Burma who had sued Unacol a TNC that had been operating in the extractive industry in Burma for many years. ${ }^{1003}$ The Burmese villagers alleged that Unacol had either directly or indirectly subjected the Plaintiffs that is the Burmese villagers to forced labour, torture, murder and rape. ${ }^{1004}$ After considering all the evidence before it, the court held that Unacol may be liable for aiding and abetting the Junta in the commission of the crime of slave labour and the court stated that that there were issues that were genuine that had to be determined to enable the court to decide whether Unacol's conduct had satisfied the actus reus and mens rea requirement for aiding and abetting the Myanmar military for the crime of forced labour. ${ }^{1005}$ However before the Doe v Unacol case could be fully litigated the case was settled and Unacol reportedly paid a huge monetary sum to the Plaintiffs in settlement of the matter. ${ }^{1006}$

\section{The Weakness Of The Alien Tort Claims Act}

The disadvantages and weaknesses of the Alien Tort Claims Act (ATCA) are, firstly the Alien Tort Statute is a creature of statute that originates in the United States, which would mean litigants would have to go to the United States to litigate their matters. ${ }^{1007}$ United States should not be the only recourse for

\footnotetext{
1002 See Doe v Unacol (2002) 395 F.3d 932 ( $9^{\text {th }}$ Cir), 14207

1003 See Doe v Unacol above n 1002, Para 1

1004 Ibid

1005 Doe v Unacol above n 1002, Para 67

${ }^{1006}$ See Rachel Chambers The Unacol Settlement: Implications for the Developing Law on Corporate Complicity in Human Rights Abuses, 14

${ }^{1007}$ For a Further list of weaknesses of the Alien Tort Claims Act, See Terry Collingsworth "Using The Alien Tort Claims Act To Hold Multinationals Accountable For Human Rights Violations in U.S. Federal Courts ,131
} 
victims who would want to litigate matters against corporations in Burma and elsewhere. $^{1008}$

Secondly, the practical consequences of litigating cases under the Alien Tort Statute is not far reaching for instance in 2002 after the much publicised case of Doe $v$ Unacol, Unacol paid the Plaintiffs that is the Burmese villagers compensation of a few million dollars. ${ }^{1009}$ However soon after the court battle was over, Unacol simply sold its shares in business in Burma to Chevron, which means the Junta is still obtaining business and making money and the human rights abuses and violations of the law continue on steadily in Burma. ${ }^{1010}$

Thirdly the judgments that can be passed on by the judges under the Alien Tort Claims Act are mainly compensatory in nature. ${ }^{1011}$ When a corporation is ordered by a court to pay monetary compensation it can always pay the monetary compensation but the root of the harm that it had caused persists and continues its existence, as was the situation in the case of Doe $v$ Unacol. ${ }^{1012}$ An international Criminal Court would have the jurisdictions to pass judgments that should be meted out to Corporations for the serious human rights abuses and violations of the law that it may be complicit in as paying a civil fine does not have the stigma of being convicted of criminal charges. ${ }^{1013}$

\section{Conclusion}

This chapter has shown that the soft laws that has been implemented to regulate TNCs has met with little or no success in its objective, the voluntary

\footnotetext{
${ }^{1008}$ See Anita Ramasastry above n 39 ,153

${ }^{1009}$ See Duncan Campbell "Energy giant agrees settlement with Burmese villagers" (15 December 2004) Guardian , United Kingdom

${ }^{1010}$ See EarthRightsInternational, The Human Cost Of Energy, above n 401

${ }^{1011}$ Jan Wouters, Leen De Smet, Cedric Ryngaert "Tort Claims Against Multinational Companies for Foreign Human Rights Violations Committed Abroad:Lessons from the Alien Tort Claims Act?" Working Paper No.46 (2003)

${ }^{1012}$ At the end of the case of Doe v Unacol,Chevron took the place of Unacol in Burma, See Amy Goodman "Chevron 's Pipeline Is Regime's Lifeline"( 8 October 2007) The Daily Camera

${ }^{1013}$ See Anita Ramasastry above n 39,153; Also See Marie Amann "Capital Punishment:

Corporate Criminal Liability For Gross Violations Of Human Rights” (2001) 24 Hastings Int'l \& Comp.L.Rev 327,336,337
} 
basis of these soft laws regulations has not deterred many TNCs from being complicit in international crimes, the TNCs in Burma is one example. ${ }^{1014}$ Suing TNCs by the host state, home state and under the ATCA is filled with problems ranging from private international law concepts such as forum non conveniens, decisions based on public policy, to limitations in terms of the kinds of crimes that TNCs can be prosecuted for. Therefore it is clear there is a need for TNCs to be accountable and answerable at an international level as this will deter TNCs from being complicit in the commission of various crimes.

${ }^{1014}$ Human rights abuses and violations of law are common in Burma where crimes such as forced labour occurs in Burma due to the joint venture projects, the TNCs undertake with the Junta .See HRC Resolution, 10/27, above n 3, para 112 


\section{CONCLUSION}

This dissertation demonstrates that based on the Rome statute of the ICC, elements of the crime and the jurisprudence of inter alia the Nuremberg, ICTY and ICTR cases the crime against humanity of slave labour and the war crime of plunder is occurring in Burma. The TNCs in Burma cannot be prosecuted for slave labour or plunder as under the existing International Criminal Law as the jurisdiction of that body of law is limited to natural persons. ${ }^{1015}$ Furthermore analysis of the role played by officials of TNCs in Burma and using the theory of complicity, aiding and abetting and the jurisprudence of the Nuremberg, ICTY and ICTR cases the officials of TNCs involved in the Yadana pipeline in Burma could be liable for being complicit and for aiding and abetting the Junta in the commission of crime against humanity of slave labour and for the war crime of plunder under International Criminal Law.

Further the research done in the area of TNCs proves that TNCs who enjoy the status of global players around the world are not adequately regulated under the law. ${ }^{1016}$ TNCs enjoyment of economic freedom far outweighs its responsibilities and obligations under the law. ${ }^{1017}$ Further suing TNCs at present is filled with problems arising from the issues such as separate legal personality of TNCs and the corporate structure of TNCs. The research done has also proved that suing TNCs in the home states, host states and under ATCA has not met with much success because there is no uniformity in laws where the suing of TNCs are concerned and the defences raised by TNCs to counter the Plaintiffs claims are based on issues dealing with jurisdictions which means that justice in many cases involving TNCs are denied.

Fafo a Norwegian Research Institute which had done research in 2006 revealed interesting facts firstly that in some countries criminal liability is applied to legal persons. ${ }^{1018}$ Secondly in certain countries there is no distinction between

\footnotetext{
${ }^{1015}$ See Rome Statute above n 34, art 25

${ }^{1016}$ See Sarah Anderson and John Cavanagh above n 856.Also See Advisory Council Of Jurist, above $\mathrm{n} 892,6$

${ }^{1017}$ Ibid

${ }^{1018}$ Anita above n 900,2
} 
legal persons and natural persons. ${ }^{1019}$ Thirdly the research also revealed the fact that some of the countries surveyed have incorporated crimes such as Genocide, war crimes and crimes against humanity which are found in the Rome Statute into their "domestic jurisprudence." 1020 As such in these countries corporations can be prosecuted for International Crimes. ${ }^{1021}$ The research done by Fafo to some extent crystallises the fact that extending the jurisdiction of the ICC to legal persons is legally feasible as many domestic jurisdictions has implemented such a mechanism.

It is recommended that TNCs be governed under International Criminal Law so that TNCs complicit in International crimes will be answerable to an independent International Criminal Court. At present the ICC only has jurisdiction over natural persons. ${ }^{1022}$ It is recommended that the jurisdiction of the ICC be extended to legal persons such as TNCs.However it is important to take note of the fact that there seems to be great reluctance on the part of the member states to extend ICC's jurisdiction to include legal persons. ${ }^{1023}$ In 1998 when the ICC statute was being drafted, France had proposed that the ICC jurisdiction be extended to cover legal persons. ${ }^{1024}$ The proposed draft statute to extend the ICC's jurisdiction to include legal persons reads as follows:- ${ }^{1025}$

The Court shall have jurisdiction over legal persons, with the exception of States, when the crimes committed were committed on behalf of such legal persons or by their agencies or representatives. The criminal responsibility of legal persons shall not exclude the criminal responsibility of natural persons who are perpetrators or accomplices in the same crimes.

The proposal by the French government was purportedly rejected by other member States on the grounds that evidential problems may arise, individual

\footnotetext{
1019 Ibid

${ }^{1020}$ Anita Ramasastry above n 900, 3

${ }^{1021}$ Ibid

1022 See Rome Statute above n 34, art 25

${ }^{1023}$ Bussiness and International Crimes-Fafo www.fafo.no/liabilities (last accesssed 20 Jun 2010)

${ }^{1024}$ Leoni Mahanta International Criminal Court: Jurisdictional Issues, 5

1025 Article 23 UN Doc A/CONF 183/2/Add.1 (1998)
} 
criminal responsibility would be diminished and the complementarily principle would become unworkable ${ }^{1026}$ Although it may be legally feasible to extend the ICC statute to cover legal persons however this extension may not find favour with many of the member states. ${ }^{1027}$

In dealing with the problem of separate legal personality of TNCs it is recommended that TNCs be incorporated by way of an International Company Law. ${ }^{1028}$ This would mean that TNCs would possess an international status. ${ }^{1029}$ The statute could take the form of an international convention. ${ }^{1030}$ Such a scheme would ensure that TNCs are dealt with as a whole unit ${ }^{1031}$ and this will also mean that TNCs are regulated at an international level under the International Criminal Court.

An international Corporate Tribunal may also be an effective mechanism to regulate TNCs where this type of Tribunal would specialize in cases where TNCs are involved. These Tribunals could be set up to hear cases which allege that TNCs have committed international crimes or are complicit in international crimes. It is imperative that TNCs as global players are regulated by the law to ensure that every entity in society is subject under the law and that equality and justice prevails. ${ }^{1032}$ Extending the jurisdiction of the ICC to cover TNCs would be in line with the law enunciated at Nuremberg.

This dissertation also proves that there are some significant similarities between the era of the Third Reich and the Junta in Burma but there are some differences as well. The Third Reich under Hitler had set out on a war of conquest in Europe and they made good progress until they were defeated by the Allies. In Burma the Junta has been committing atrocities against its own people for

\footnotetext{
${ }^{1026}$ See Leoni above n 620 . Also See Bussiness and International Crimes-Fafo www.fafo.no/liabilities (last accessed 20 Jun 2010)

${ }^{1027}$ Ibid

${ }^{1028}$ See United Nations Conference On Trade and Development, Programme on Transnational Corporations, World Investment Report 1993, Transnational Corporations And Integrated International Production (1993) New York ,189

${ }^{1029}$ Ibid

${ }^{1030}$ Ibid

${ }^{1031}$ Ibid

${ }^{1032}$ See Universal Declaration Of Human Rights, G.A. Res 217 (III) UN GAOR, $3^{\text {rd }}$ Sess, Supp.No 13, UN Doc.A/810 (1948)
} 
decades, ${ }^{1033}$ however since the Junta's actions are only against its own people there is no external forces that can put an end to the atrocities in Burma. On a legal premise extending liability to the Junta and officials of the TNCs in Burma under International Criminal Law would prove to be "one of the most significant tributes ever paid by power to reason." 1034

\footnotetext{
${ }^{1033}$ See HRC Resolution, above n 3,para 121

${ }^{1034}$ See Henry T.King Jr "Spirit Of Nuremberg-Idealism" (2008) 39 Stud.Transnat'l Legal Policy 33,40
} 


\section{BIBLIOGRAPHY}

\section{Primary Material}

\section{A International Legislation}

Control Council Law No.10

Convention (IV) respecting the Laws and Customs of War on Land and its annex: Regulations concerning the Laws and Customs of War on Land. The Hague, 1907

(adopted on 18 October 1907,entered into force 26 January 1910)

Convention On Civil Liability for Oil Pollution Damage,1969 (adopted on 29 November 1969, entered into force 19 June 1975)

Convention (II) for the Amelioration of the Condition of Wounded, Sick and Shipwrecked Members of Armed Forces at Sea.Geneva, 12 August 1949 (entered into force 21 October 1950)

Convention (III) relative to the Treatment of Prisoners of War.Geneva, 12 August 1949 (adopted 12 August 1949, entered into force 21 October 1950)

Forced Labour Convention 1930,Geneva (adopted 28 June 1930, entered into force 1 May 1932)

Protocol Additional to the Geneva Conventions of 12 August 1949, and relating to the Protection of Victims of International Armed Conflicts (Protocol I), 8 June 1977 (adopted 8 June 1977, entered into force 7 December 1978)

Protocol Additional to the Geneva Conventions of 12 August 1949, and relating to the Protection of Victims of Non-International Armed Conflicts (Protocol II), 8 June 1977

( adopted 8 June 1977, entered into force 7 December 1978)

Rome Statute Of The International Criminal Court A/CONF.183/9, 17 July 1998

Slavery Convention, Geneva, 25 September 1926 (adopted 25 September 1926 , entered into force 9 March 1927)

Statute Of The Special Court Of Sierra Leone (established pursuant to Security Council Resolution 1315)

Statute Of The International Criminal Tribunal Of Yugoslavia (ICTY)

Universal Declaration Of Human Rights 


\section{B Domestic Legislation}

\section{United States}

Alien Tort Claims Act of 1789

\section{United Kingdom}

Corporate Manslaughter and Corporate Homicide Act 2007

\section{Reports}

Collignon,Stefan The Burmese Economy: Report on The Burmese Economy And The Withdrawal Of European Trade Preferences (prepared for The European Institute For Asian Studies 1997) 6

Elsea,Jennifer :International Criminal Court: Overview and selected Legal Issues (Report prepared for Congress 5 June 2002)

EarthRights International Earth Rights Abuses by Corporations in Burma Collective Summary and Recommendations: Report of Abuses by Corporations in Burma (prepared for submission to the Special Representative on the issue of Human Rights and Transnational Corporations and other Business Enterprises, 2005)

EarthRights International China In Burma: Report of the increasing investment of Chinese Multinational Corporations in Burma's Hydropower, Oil, and Natural Gas and Mining Sectors (2008) 7-9

Earthrights International The Human Cost Of Energy: Chevron's Continuing Role In Financing Oppression And Profiting From Human Rights Abuses in Military-Ruled Burma (Myanmar): Report of Chevron's role in Burma (prepared for the Promotion and Protection of human rights in Burma,2008)

Earthrights International Forced Labor Along the Yadana and Yetagun Pipelines ( Supplemental Report To More Of The Same : Forced Labor Continues In Burma ( October 2000-September 2001)

Falco,Mathea Burma: Time for Change: Report of an independent Task Force (prepared for The Council Of Foreign Relations of United States of America, 2003) 
International Human Rights Clinic At Harvard Law School (IHRC) "Crimes In Burma" :Reports of War Crimes and Crimes Against Humanity in Burma (report prepared to call on the UN Security Council to establish a commission of inquiry in Burma, May 2009)

International Confederation Of Free Trade Unions (ICFTU) Doing Business In Or With Burma:Report of the consequences of doing business in or with Burma (prepared for the International Confederation of Free Trade Unions (ICFTU)2005)

International Peace Academy and Fafo, Business And International Crimes : Assessing the Liability of Business Entities for grave violations of International Law Norway, 2004, 23.

International Commission Of Jurists Corporate Complicity And Legal Accountability Volume 1 Facing The Facts And Carting A Legal Path: Report Of The International Commission Of Jurists Expert Legal Panel On Corporate Complicity in international Crimes (prepared to explore the issue as to the kind of conduct that a company should avoid to ensure that it does not become complicit in gross human rights abuses, Geneva 2008)

International Commission Of Jurists Corporate Complicity And Legal Accountability Volume 2 Criminal Law And International Crimes: Report Of The International Commission Of Jurists Expert Legal Panel On Corporate Complicity in international Crimes (prepared to explore the issue as to in what circumstances international criminal law could hold companies and /or their officials criminally responsible when they are involved with others in gross human rights abuses that amounts to crime under international law, Geneva, 2008)

International Commission Of Jurists Corporate Complicity And Legal Accountability Volume 3 Civil Remedies: Report Of The International Commission Of Jurists Expert Legal Panel On Corporate Complicity in international Crimes (prepared to explore the law of domestic civil liability and the ways in which, across jurisdictions, civil liability may arise for companies and/ or their officials when they are complicit in gross human rights abuses, Geneva 2008)

International Peace Academy And Fafo Business and International Crimes, Assessing the Liability of Business Entities for Grave Violations of International Law (2004)

Oxford Pro Bono Public Obstacles To Justice And Redress For Victims Of Corporate Human Rights Abuse ( a comparative submission prepared for Professor John Ruggie UN Secretary-General's Special Representative On Business \& Human Rights, 2008) 
Rudnick,Piper Gray Cary Threat to the Peace: A Call for the UN Security Council to Act in Burma :Report on the Threat to the Peace in Burma (Report commissioned by The Honourable Vaclav Havel, Former President of the Czech Republic and Bishop Desmond M.Tutu, Archbishop Emeritus of Cape Town, and prepared for UN Security Council to act in Burma, 2005) 10,11

Report submitted by State parties under article 18 of the Convention on the Elimination of all forms of Discrimination against women (25 June 1999)CEDAW/c/MMR/1

Ramasastry,Anita and Robert C.Thompson Commerce, Crime and Conflict Legal Remedies For Private Sector Liability For Grave Breaches Of International Law, A Survey Of Sixteen Countries,(Fafo- report 536) Norway (2006)

Turnell,Sean Burma's Economic Prospects: Report on the Prospects of Burma's Economy (prepared to be tendered as Testimony before the Senate Foreign Relations Subcommittee on East Asian and Pacific Affairs,2006)

United States Department Of Labour Report On Labour Practices In Burma: Report of Forced Labour and Child Labour in Burma (prepared for the United States Department of Labor,1998)

\section{United Nations Documents}

HRC Resolution 5/1 Human Rights Situation That Requires The Council's Attention (7 March 2008) A/HRC/7/18

John Ruggie 2009 Human Rights And Transnational Corporations and other Business Enterprises A/HRC/8/5 (2008)

Report on HRC Resolution 10/27 Human Rights Situation That Requires The Council's Attention (10 March 2010) A/HRC/13/48

Situation Of Human Rights In Myanmar GA Res 63/245,A/Res/63/245 (2009)

Sergio Pinheiro,Paulo Special Rapporteur On The Situation Of Human Rights In Myanmar "Report on the situation of human rights in Myanmar" ( 11 December 2007) $\mathrm{A} / \mathrm{HRC} / 6 / 14$

United Nations Conference On Trade and Development , Programme on Transnational Corporations, World Investment Report 1993, Transnational Corporations And Integrated International Production (1993) New York 
UN Secretary- General Kofi Annan "The Protection Of Civilians in Armed Conflict" S/2002/1300, Report of the Secretary -General to the Security

Council, 26 November 2002 , Para 58

United Nations War Crimes Commission Digest Of Law And Cases ( UNWCC 1949)

United Nations Conference On Trade And Development, The Universe Of The Largest Transnational Corporations, Geneva (2007)

UNGA Resolution 1803 (XVII) on Permanent Sovereignty Over Natural resources (14 December 1962)

United Nations War Crimes Commission, Digest Of Laws And Cases (Volume $\mathrm{XV}$ )

United Nations Conventions on the Law Of the Sea (10 December 1982) 1833

UNTS 3. (The Convention entered into force on 16 November 1994)

United Nations Conventions Against Transnational Organized Crime 2000 (opened for signature 12-15 December 2000 , entered into force 29 September 2003 )

\section{E Speeches}

Aung San Suu Kyi, NLD Secretary General "For Us, Every Day is a Special day for Democracy" (Statement in World Voice Campaign and Burma Campaign UK September 1999)

Telford Taylor, Chief Prosecutor Of The Twelve Subsequent Trials at Nuremberg-"The Importance Of The Nuremberg Trials" (2006, Nuremberg Trials $60^{\text {th }}$ Anniversary )

\section{F Newspapers and Non- Academic Periodicals}

Africa News "South Africa, Country Condemns Burmese Rights Violations" (14 February 2007)1

A.Graham,Robert S.J “The Right To Kill” In The Third Reich. Prelude To Genocide.’(1976) 62 The Catholic Historical Review.

“Burma's Agony” (7 May 2008) Daily News New York 
Bagnall,Janet "Ottawa should bar companies from trading with Myanmar; Money spent in that country serves to only prop up the Junta" (5 October 2007)The Gazette Montreal, A25

Beech, Hannah "Race For Burma's Riches-the New Great Game" (30 March 2009) Time New Zealand.

Boot,William “China's Grip On Burma 'Cause for Concern' "(29 September 2008) The Irrawaddy Thailand.

Boot,William "China Eying Burma as a "Conduit" for Oil and Gas Supplies" (12 April 2007) The Irrawaddy Bangkok Thailand

Brunner,Joseph "American Involvement In The War Crimes Trial Process"

Baker,David R. "Chevron's links to Burma stir critics to demand it pull out" (4 October 2007) The San Francisco Chronicle

Beech,Hannah ,Pyin U Lwin “Soldiers of Fortune” (26 July 2010) Time

Crow,Patrick “Myanmar Sanctions” (28 April 2007) Oil \& Gas Journal Tulsa United States, 37

Cusano,Chris "Burma: Displaced Karens.Like Water on the Khu Leaf"

Collingsworth,Terry "Using The Alien Tort Claims Act To Hold Multinationals Accountable For Human Rights Violations in U.S. Federal Courts

Campbell,Duncan "Energy giant agrees settlement with Burmese villagers" (15 December 2004) Guardian, United Kingdom

Chambers, Rachel "The Unacol Settlement: Implications For The Developing Law On Corporate Complicity in Human Rights Abuses."

“Change comes to Myanmar,but only on the Junta's Terms."New York Times(17 March 2010)

G.Pascal , .Zachary "U.S Companies back out of Burma, citing human-rights concerns,graft” (13 April 1995)The Wall Street Journal New York

Genser,Jared "A Path To Peace In Burma"(December 2005) Far Eastern

Economic Review Hong Kong

Goodman,Amy “Chevron's pipeline Is Regime's Lifeline” (8 October 2007) The Daily Camera, Colorado 
Girion ,Lisa "US Ruling Says Firms liable For abuse abroad” (19 september 2002)The Los Angeles Times.

Hiatt, Fredd "In Burma, a U.N. Promise Not Kept" (12 May 2008) Washington Post Washington

Kazmin, Amy “IMF warns Burma on High Inflation” ( 11 October 2006) Financial Times London (UK)

Kazmi,Salman Is Victor's Justice in Nuremberg Trial Justified or not?

Kurlantzick,Joshua "Playing us for fools ; Burma's government is run by a group of ignorant xenophobes. So how come it keeps outsmarting us?" (11 July 2008) The New Republic Canada A13

Lwin,Min "Regime Goal: The Strongest Army in Southeast Asia" (20 August 2009) The Irrawaddy, covering Burma and Southeast Asia.

Mallet, Victor "Do Not give Up On The Burmese revolution yet;"[ Asia Edition] (11 October 2007) Financial Times London 11

Moe,Wai "No Compromise Says Junta Mouthpiece"(19 November 2007) The Irrawaddy Bangkok Thailand

"Nuremberg Trials $60^{\text {th }}$ Anniversary" (2006) Dimensions Journal of Holocaust Studies

Pepper,Daniel "In Burma, business ventures start with military" ( 13 November 2008) The San Francisco Chronicle

Robinson,Simon "India's Burma Silence Says Volumes" ( 29 September 2007) Time New Delhi, India, 2

Roughneen,Simon "Lifting the mask-Irrawaddy" (1 July 2010) The Irrawaddy

Smith,Matthew and Naing Htoo "Gas Politics : Shwe Gas Development in Burma”(Nov 2005-Jun 2006) 11 Watershed 9

Suwanvanichkij, Voravit "Displacement and disease: The Shan exodus and infectious disease implications for Thailand" (14 March 2008) Conflict and Health

Smith, Matthew "Focus /Burma: The Hunt For Energy At Any Cost, The Politics of doing business with a brutal regime" (15 November 2007) Bangkok Post Thailand

Shaw,Jeff "Out Of Burma; Grassroots Activism Forces Multinationals To End Ties With The Burmese Dictatorship" (29 February 2004) Multinational Monitor Washington 
Sedivy,David “Germany WW I and WW II Overstretch

Sisodia,Rajeshree , Andrew Buncombe "Burmese villagers forced to work on Total pipeline" (14 August 2009) The Independent, Asia

Tutu,Desmond "Easy Praise Empty Words" (14 August 2006) New Statesman London

Turnell,Sean "The Rape of Burma : Where did the wealth go?" (2 May 2008) The Japan Times

The Shwe Gas Bulletin "Indian Essar Oil Company Exploration Damages People's Properties" (20 February 2008)

Utley,Garrick “John J. McCloy and the "Splendid Reconciliation” 1

Westerkamp, Meike "International Conference on Transnational Corporations and Human Rights In Berlin” (2008) ECC Newsletter

Watkins, Eric "China Courts Myanmar” ( 22 January 2007) 105 Oil \& Gas Journal Tulsa, United States of America

Washington Post “Russia, China Veto Resolution On Burma” (13 January 2007)

Yan Naing, Saw “UN Fails To Investigate War Crimes In Burma: Harvard Report" (22 May 2009) The Irrawaddy, Bangkok Thailand.

Zagorin,Adam “Slave Labor?” (30 November 2003)Time

\section{G Letters}

Abraham Lincoln, $16^{\text {th }}$ President of the United States, to Colonel William F. Elkins (21 November 1864) Letter

\section{SECONDARY SOURCES}

\section{A Books}

Cassese, Antonio International Criminal Justice ( $1^{\text {st }}$ ed, Oxford University Press, New York 2009)

C. Sutton,Anthony Wall Street and the Rise of Hitler (GSG Publishers ,2002) 
Fink,Christina Living Silence Burma Under Military Rule $\left(1^{\text {st }}\right.$ ed, Zed Books Ltd,London 2001)

Haacke,Jurgen Myanmar's Foreign Policy Domestic Influences And International Implications (1 ed Routledge, London,2006) 86

Henckaerts and Doswald-Beck Customary International Humanitarian Law Volume 1(Cambridge, Cambridge University Press, 2005)

Myint -U, Thant The River Of Lost Footsteps (1 ed, Farrar,Strauss and Giroux,United States,2007)

Morrisson,Ian Grandfather Longlegs: The Life And Gallant death of Major H.P. Seagrim (1ed, Faber \& Faber, London ,1947)

Maung, Maung A Trial In Burma (1 ${ }^{\text {st }}$ ed, Martinus Nijhoff, The Hague,1962)

Naw, Angelena Aung San And The Struggle For Burmese Independence $\left(1^{\text {st }} \mathrm{ed}\right.$, Silkworm Books, Thailand,2001)

Ott,Marvin From Isolation To Relevance in Burma: Prospects for

Democratization (Brookings Institute Press Washington, 1998) 79

South,Ashley Ethnic Politics In Burma (1 ed, Routledge,London, 2008)228-229

Sang Suu Kyi, Aung Freedom From Fear And Other Writings (1st ed, Viking Penguin, USA, 1991)

Tucker,Shelby Burma The Curse Of Independence (1 ed Pluto Press USA 2001)

Tiburcio,Carem The Human Rights of Aliens under International and

Comparative Law (Kluwer Law International,The Hague, The Netherlands, 2001)

The Bigger Picture "The Origin Of Pharmacuetical Colonialism” 146

Tutu,Desmond “Believe The Words And Inspiration Of Desmond Tutu " ( 1 st ed, Hachette, 2007) 26

Vandana Shiva, B.K.Keayla TNCs The Real Architects of TRIPS(New Delhi,1995)

\section{B Journals and Articles}

Aldred, Carolyn "Human Rights Seen As Business Issue" (17 April 2000) Business Insurance 30 
Aguero,Jeff "Risky Business: Integrating Transnational Corporations Into The Human Rights Arena" (2006)

Ascoly,Nina "With Power Comes Responsibility, Legislative Opportunities To Improve Corporate Accountability at EU level" (European Coalition For Corporate Justice, May 2008)

Anderson,Sarah and John Cavanagh “Top 200 : the Rise Of Corporate Global Power"

(2000)

Amnesty International Crimes Against Humanity In Eastern Myanmar AI index: ASA 16/011/2008, 5 June 2008

Bassiouni,M.C Cherif "Universal Jurisdiction For International Crimes:

Historical Perspective and Contemporary Practice" (2001) 42 Va.J.Int'1 L 82, 82

Braul,Waldemar, Paul Wilson "Parent Corporation Liability For Foreign Subsidiaries"

Ballentine,Karen, Heiko Nitzschke "Profiting from Peace:Managing The Resource Dimensions Of Civil War" (1 $1^{\text {st }}$ ed, Lynne Rienner, USA,2005) 3

Blumberg,Philip The Multinational Challenge To Corporation Law: The Search for a new corporate personality (1993) 169

Ballentine,Karen "Economic Agendas In Civil Wars: Program On Economic Agendas in Civil Wars:" Principal Research Findings and Policy Recommendations, New York 2004.

Collingsworth, Terry "Using The Alien Tort Claims Act To Introduce The Rule Of Law To The Global Economy" (International Labour Rights Fund, Washington D.C 2005)

Clapham, Andrew And Scott Jerbi “ Categories Of Corporate Complicity In Human Rights Abuses” (2001) 24 Hastings Int'1 \& Comp.L.Rev.339,340

Clapham,Andrew “On Complicity” 2002 Le Droit Penal A L'epreuve de L'internationalisation 241,275

Cheverie,John "United States Court Finds Unacol May Be Liable For Aiding And Abetting Human Rights Abuses in Burma" (2002) 10 HR Brief 6

Costi,Alberto "Hybrid Tribunals As A Valid Alternative To International Tribunals For The Prosecution Of International Crimes" (2005) NZLR 1,3 
Clapham, Andrew "The Question Of Jurisdiction Under International Criminal

Law Over Legal Persons: Lessons From the Rome conference on an International Criminal Court' in M.Kamminga and S. Zia -Zarifi, Liability Of Multinationals Corporations under international law (2000)

Cassel ,Doug “Corporate Aiding And Abetting Of Human Rights Violations :Confusion in the Courts” (2008) Northwestern J IHR 304,306

Cassese, Antonio “International Law In A Divided World”, (1986) 103

De Jonge,Alice "Expanding the Limits Of Corporate Responsibility: An Institutional Approach”(2008) Monash Business Review

Deva,Surya "Acting Extraterritorially to tame Multinational Corporations for Human Rights Violations:Who Should Bell The Cat?” (2004) MelbJIntLaw

D.Fearon.,James , D.Laitin David "Burma Random Narratives" in James D.Fearon and David D.Laitin in Burma Random Narratives (Stanford university) 2007

Danailov, Silvia "The Accountability of Non-State Actors for Human Rights Violations: The special case of Transnational Corporations" ( Geneva,October 1998)

EarthRights International, centre for constituitional rights "Settlement Reached in Human Rights Cases Against Royal/Dutch Shell.

Elston Suzanne "Global Economy Shifting The Balance Of Power" ( 2001) Flynn, Greg Robert O'Brien "An International Western Labour Response To The Globalization Of India And China” (2010) Global Law J 191, 193

Guyon, Rudy "Violent Repression In Burma : Human Rights And The Global Response" (1991) 10 Basin L.J, 410, 424

Green ,Michael and Derek Mitchell “Asia's forgotten crisis: a new approach to Burma" (2007) Foreign Affairs 3

Gotzmann,Nora "Legal Personality Of The Corporation and International Criminal Law: Globalisation, Corporate Human Rights Abuses and the Rome Statute" (2008) 1 QLSR 38,49

Gibb,Michael “Taming Trans-Nationals” Earth, Exploitation and Survival,2

Hillemanns, Carolin "UN Norms on the Responsibilities of Transnational Corporations And Other Business Enterprises with Regard To Human Rights" (2003) 10 Ger LJ 1 
Haigh,Kathryn "Extending the International Criminal Court's jurisdiction to Corporations: overcoming complementarity concerns" (2008) 14 (1) AJHR 199,202

Hertz,Richard "Text Of Remarks : Corporate Alien Tort Liability And The Legacy Of Nuremberg” (2006) 10 Gonz J Int'1 ,76,76

Hutchens, Kristen “ International Law In The American Courts -Khulumani v Barclay National Bank Ltd: The Decision Heard 'Round The Corporate World" (2008) 9 Ger LJ 639

Joseph Burke,Robert JR “ Turning The Lens Inward : Focusing on International Human Rights Issues In Burma (1996) 4 Willamette Bull.Int'1 L \& Pol'y 87,87

John Perry,Peter “ Military Rule In Burma: A geographical analysis” (1993)19 Crime Law and Social Change 17 for a geographical analysis of the Military rule in Burma

Kronforst, Lucy “Transnational Corporations And Human Rights Violations: Focus On Colombia”23 Wisconsin Int LJ

Kinley, David \& Junko Tadaki , “From Talk To Walk, The Emergence Of Human Rights Responsibilities For Corporations At International Law "(2004) 44 Va Jlnt'1 L 933,933

Kaleck,Wolfgang and Miriam Saage-MaaB “ Transnational Corporations On Trial On The Threat To Human Rights Posed By European Companies in Latin America"(A Study By Wolfgang Kaleck and Miriam Saage-MaaB, vol 4 ) (Heinrich Boll Foundation,2008)

Kreide,Dr Regina "The Obligations Of Transnational Corporations in the Global Context" (Prepared For delivery at the 2007 Pisa meeting of the European Consortium of Political Research, 2007)

Kaeb,Caroline "Emerging Issues Of Human Rights Responsibility in the Extractive and Manufacturing Industries: Patterns and Liability Risks" (2008) 6:2 NorthWestern JInt'lHR, 327, 334

King,Henry T. Jr “Spirit Of Nuremberg-Idealism” (2008) 39 Stud.Transnat'1 Legal Pol'y 33,40

Korbin J, Stephen "Private Political Authority And Public Responsibility: Transnational Politics, Transnational Firms and Human Rights" (2008) U Penn 1,3

Lane,Melissa "Autonomy as a central human right and its implications for the moral responsibilities of corporations" 148 in T. Campbell and S.Miller, 
"Human Rights And The Moral, responsibilities of corporate and public sector organizations" (2004) Kluwer Academics, Netherlands.

Mahanta,Leoni International Criminal Court: Jurisdictional Issues, 5

Magraw,Kendra "Universally Liable? Corporate-Complicity Liability Under The Principle Of Universal Jurisdiction” (2009) 18 Minn.J.Int'I L 458,470

Maung Win,Khin "Legal Issues On Burma Journal No.6” (18 July 2000) The Nation, Burma

Muchlinski,Peter. "Human Rights and Multinationals Is there a problem?" (2001)77 Int'l L Affairs 31, 37

Meeran,Richard “Liability Of Multinational Corporations: A Critical Stage” 1

Marie Amann,Dianne "Capital Punishment:Corporate Criminal Liability For Gross Violations Of Human Rights" (2001) 24 Hastings Int'1 \& Comp. L. Rev $327,336,337$

Muchlinski, Peter "Corporations In International Litigation:Problems of Jurisdiction And The United Kingdom asbestos cases”(2001) 50 Int'1 Com LQ

Nolan,Justine "With Power Comes Responsibility: Human Rights And Corporate Accountability”(2005) U NSW L J 38

Philips,Craig, Rachel Nicolson, Jess Moir, "International Law , Human Rights and Corporations:Emerging Issues" ( Paper prepared for the IBA Conference, October 2007)

Penrose,Mary Margaret "Lest We Fail: The Importance Of Enforcement In International Criminal Law" (2000) 15 AM.U.Int'L L.Rev 321, 330

Rolston, Michael "Globalizing a Traditional Cottage Industry:International Criminal Organizations in a Global Economy” (2007) 6 Globalization 1,1

Ratner, Steven R. “Corporations And Human Rights A Theory Of Legal Responsibility” (2001) 111 YLJ 443, 500.

Riordan, Kevin "Protecting Fundamental Human Rights In Times Of War-The Means And Methods of Warfare"(2005) NZLR

Ramasastry,Anita "Corporate Complicity: from Nuremberg To Rangoon An Examination of Forced Labor Cases and Their Impact on the liability of Multinational Corporations" (2002) 20 Berkeley J.Int'1 L 91, 153

Ramasastry,Anita and Eric Mongelard "Corporate Civil Liability For Violations Of International Humanitarian Law.”(2006) 88 IRRC, 676 
Ramasastry, Anita "Mapping The Web Of Liability : The Expanding Geography Of Corporate Accountability in Domestic Jurisdictions (2008)

Ramasastry, Anita "Secret and Lies? Swiss Banks and International Human Rights" (1998) 31 Vand. J.Transnat'1 L 325, 449

Skinner,Gwynne "Nuremberg Legacy Continues: The Nuremberg Trials' Influence On Human Rights Litigation In U.S. Courts Under The Alien Tort Statute (2008) 71 Albany L Rev 321,321.

Shnayerson, Robert "Judgment at Nuremberg"

Slye,Ronald C. "Corporations, Veils And International Criminal Liability" (2008) 33 Brook J.Intl'l L, 955, 960

Schabas A,William "Enforcing International Humanitarian Law:Catching the accomplices (2001) 83 IRRC, 439, 442

Schabas A,William "War Economics, Economic Actors and International Criminal Law",2

Swanson, Philip Fuelling Conflict The oil Industry and armed conflict (Fafo Report 378) 29,30

Thames,Knox "The effectiveness of US litigation against MNCs in Burma" (2000) 11 HRD

Taylor,Mark B. "Corporate Fallout Detectors and Fifth Amendment Capitalists: Corporate Complicity in Human Rights Abuses", Global Compact Learning Forum,(2003) 2

Turnell, Sean “Burma's Economy 2008: Current Situation And Prospects For Reform"(2008) 15

Voices of '88-Burma's struggle for democracy.Open Society Institute,1998, Part 1 Myanmafication-Imprisoning Burma,119

Vertannes, Rachel Schairer "The Politics Of Human Rights:How The World Has Failed Burma” (2001) 2 APacJHR L 77,78

World Investment Report “TNCs and Integrated International Production” 189

Weschka, Marion Human Rights And Multinational Enterprises: How can Multinational Enterprises Be Held Responsible for Human Rights Violations Committed Abroad? 
Wells,Celia and Juanita Elias "Holding Multinational Corporations Accountable for breaches of Human Rights"( Centre For Business Relationships

Accountability Sustainability and Society, Cardiff University)

Wagner, Markus "Corporate Criminal Liability National and International Responses" (Background Paper For The International Society For the Reform Of Criminal Law , $13^{\text {th }}$ International Conference, Commercial And Financial Fraud, A Comparative Perspective, Malta 1999)3,4

\section{Electronic Sources}

Appellees v Union Carbide Corporation 809 F.2d 195 Also see In reunion Carbide Corp. Gas Plant Disaster at Bhopal http://www.uniset.ca (accessed 12 February 2010)

Armed Conflicts Report-Burma www.ploughshares.ca/libraries/ACRText/ACR-Burma.html ( accessed 14 May 2009)

Aumonitor/Khulumani v Barclays Case www.pambazuka.org/aumonitor/comments/420 (accessed 14 May 2009)

AxisofLogic-Judge Narrows Claims in Apartheid Torts Case Against Multinational Corporations axisoflogic.com/artman/publish/Article 55422.shtml (accessed 14 May 2009)

ASEAN-Burmese Relations:Past,Present and Future www.idea.int/asia_pacific/burma/upload/exec_summary.pdf (accessed 8 June 2009)

Adolf Hitler and The Holocaust www.auschwitz.dk/Hitler (accessed 12 July 2010)

Burma Today:www.burmalibrary.org/reg.burma/(accessed 24 October 2008)

Burma Action Ireland www.columban.com/burma ireland.html (accessed 11 January 2009)

BBC News World Asia Pacific Where The World stands on Burma http://newsvote.bbc.co.uk (accessed 12 April 2009)

Burma's Faceless Leaders http://www.time.com/time/ (accessed 1 November 2008)

Burma:India shamed into revising stand on junta http://ipsnews.net/news (accessed 10 January 2009)

Burma After the Death Of Aung San www.sjsu.edu/faculty/watkins/burma2.htm(accessed 3 November 2008) 
Burma 's Struggle For Democracy: The Army Against The People http://epress.anu.edu.au (accessed 19 November 2008)

Burma Campaign UK,Business \& Human Rights: Burma (Myanmar) The Burma Campaign Dirty List www.burmacampaign.org.uk/dirty ( accessed 24 February 2009)

Burma : Foreign Investment Finances Regime/Human Rights Watch http://www.hrw.org/en/news/2007/10/01/burma-foreign -investment-finances -regime (last accessed 27 February 2009)

Burma : Country in Crisis www.asiaobserver.com/Burma/Burma-backgrounddrugs.htm (accessed 14 May 2009)

Business And International Crimes-Fafo/Crimes against Humanity http://www.fafo.no/liabilities/part_II-1crim-hum.htm

Business And International Crimes-Fafo/War Crimes I www.fafo.no/liabilities/part II-3war-crim.htm

Business and International Crimes-Fafo/Forced labor-Enslavement http://www.fafo.no/liabilities/part_II-2forc-lab.htm (accessed 14 May 2009)

Business And International Crimes http://www.fafo.no/liabilities/rec-dev.htm (accessed 6 March 2009)

Case 10, The Krupp Case http://www.ushmm.org/wlc/article (assessd 1 April 2009)

Corporate Manslaughter and Corporate Homicide Act 2007 (c.19) www.opsi.gov.uk/acts/acts 2007 (accessed 14 May 2009)

Control Council Law No.10: Genocide and Crimes Against Humanity www.enotes.com/genocide-encyclopedia/control-council-law-no-10 (accessed 22 May 2009)

CEO Observer Issue 4-WTO Millenium Bug:TNC Control Over Global Trade Politics http://archive.corporateeurope.org/wto (accessed 14 April 2010)

Drowning, Can the Burmese people rescue themselves? http://www.lexisnexis.comhelicon.vuw.ac.nz (accessed 1 November 2008)

EarthRights International -Chevron and the Yadana Pipeline www.earthrights.org/campaignfeature/yadana pipeline.html (accessed 14 May 2009) 
Earthrights International -Shwe Gas Project in Burma:Recent Developments Shwe_gas_project_in_burma (accessed 14 May 2009)

Find Law's Writ-Ramasastry:Banks And Human Rights http://writ.news.findlaw.com/ramasastry (accessed 14 May 2009)

Flick Trial www.loc.gov/rr/frd/Military-Law/Pdf/NT_war-criminals_Vol-VI.pdf (accessed 14 February 2009)

Getting it Wrong: Flaws " Corporate Social Responsibility” and Misrepresentations Surrounding Total and Chevron's Yadana Gas pipeline in Military-Ruled Burma (Myanmar) www.earthrights.org (accessed 12 July 2010)

History-Voices For Burma www.voicesforburma.org/about/history (accessed 24 October 2008)

History of the United Nations www.un.org/aboutun/unhistory (accessed 12 July 2010)

Human Rights:Quotable www.un.org/cyberschoolbus/humanrights/resources/quotable.asp (accessed 14 June 2009)

Human Rights abuses -Shwe Gas Movement www.shwe.org (accessed 12 July 2010)

History Of Burma www.cfob.org/index ( accessed 25 october 2008)

House Of Lords-Connelly (A.P) v R.T.Z Corporation Plc and Others http://www.parliament.the -stationery-office .co.uk (accessed 11 April 2010)

History Of Burma (Myanmar) www.historyofnations.net/asia/burma (accessed 24 October 2008)

IPEIE-Burma (Myanmar): Forced Labor In The World's Last Teak Forest http://www.ratical.org/ratville/IPEIE/Burma.html (accessed 14 May 2009)

International Humanitarian Law-Principles Nuremberg Tribunal 1950 www.icrc.org (accessed 30 June 2010)

ICEM-India and China to boost forced labour in Burma http://www.icem.org (last accessed 14 May 2009)

International Humanitarian Law-Hague Convention IV 1907 http://www.icrc.org (accessed 11 February 2010)

International Humanitarian Law-Fourth 1949 Geneva Convention www.icrc.org (accessed 11 February 2010) 
International Humanitarian Law-First 1949 Geneva Convention www.icrc.org (accessed 11 February 2010)

International Humanitarian Law-Additional Protocol 11977 www.icrc.org (accessed 11 February 2010)

International Humanitarian Law-Additional Protocol II 1977 www.icrc.org (accessed 11 February 2010)

International Relations Key Issues-ALTESAN Burma

www.altesan.org/KeyIssuesInternational.htm (accessed 22 September 2008)

IISS Armed Conflict Database Annual Update 2007

http://acd.iiss.org/armedconflict (accessed 14 April 2010)

International Convention On Civil Liability For Oil Pollution Damage www.admiraltylawguide.com (accessed 10 April 2010)

Investment.Impact of TNC www.oaklandpl.org (accessed 12 July 2010)

Josef Silverstein-Burma's Uneven Struggle-Journal Of Democracy 7:4

http://muse.jhu.edu/journals/journal_of_democracy/v007/7.4silverstein.html (accessed 15 May 2009)

Junta Signs Gas Deals With Thailand-Shew Gas Movement www.shwe.org/archives/junta-signs-gas-deal-with-thailand (accessed 10 February 2009)

Josef Silverstein-Burma's Uneven Struggle-Journal Of Democracy 7:4 http://muse.jhu.edu/journals/journal_of_democracy/v007/7.4silverstein.html (accessed 15 May 2009)

Junta Signs Gas Deals With Thailand-Shew Gas Movement www.shwe.org/archives/junta-signs-gas-deal-with-thailand (accessed 10 February 2009)

LaborNET: workers Online Live News Feed: ILO Sanctions Against Burma www.labor.net.au/news/626.html (accessed 20 April 2009)

Military Rule :First Phase, 1962-1974, Burma 's Struggle For Democracy :The Army Against the People http://epress.anu.edu.au (accessed 19 November 2008)

Military Rule: Third Phase, 1988-1993 Burma's Struggle For Democracy : The Army Against The People http://epress.anu.edu.au (accessed 19 November 2008)

Myanmar: Burma condemned over slave labour http://www.asyl.net/Magazin/Docs/docs(accessed 14 May 2009)

Myanmar-International treaties adherence www.adh-geneva.ch (accessed 11 February 2010) 
Myanmar: Amnesty International calls for comprehensive international arms embargo http://www.amnesty.org (accessed 10 January 2009)

Nuremberg defence doesn't make the grade -Business-Business-the age.com.au www.theage.com.au/news/business/nuremberg (accessed 20 March 2009)

Nuremberg Principles. International Humanitarian Law-Principles Nuremberg Tribunal 1950www.icrc.org (accessed 30 June 2010)

Nazi Party 1934-1939 www.historyplace.com/worldwar2/triumph (accessed 14 July 2010)

NGO Proposals on Natural Resources and Conflict-UN Security Council Global Policy Forum http /security/natres/generaldebate(accessed 14 May 2009)

Once The Ricebowl of Asia, The military Destruction of Burma's economy (1) www.burmalibrary.org/doc/ricebowl98.htm (accessed 14 May 2009)

Opening Statement before the International Military Tribunal www.roberthjackson.org/Man/theman2-7-8-1/ (accessed 9 June 2009)

Overview Of The UN Global Compact www.unglobalcompact.org/Aboutthe GC (accessed 16 June 2009)

Political and Economic History Of Myanmar (Burma)

www.sjsu.edu/faculty/watkins/burma2.htm (accessed 1 November 2008)

Protracted crisis in Eastern Burma www.odihpn.org/report (accessed 12 July 2010)

Reference For Burma-http://search.com/reference/Burma (accessed 1 November 2008)

Rebuilding The 'Rice Bowl' www.irrawaddy.org/article (accessed 1 November 2008)

Rome Statute Of the International Criminal Court (Articles 1 to 33)-Prevent genocide International www.preventgenocide.org/law/icc/statute/part-a.htm (last accessed 12 May 2009)

Red Flags http://www.redflags.info/ (accessed 15 May 2009)

Soft law and the state -Market Relationship http://www.u-tokyo.ac.jp/coe (accessed 21 March 2009)

Statute of the International Criminal Tribunal for the Prosecution of Persons Responsible for Serious Violations of International Humanitarian Law Committed in the Territory of the Former Yugoslavia since 1991 see United 
Nations (UN): International Law Documentation www.un.org (accessed 30 June 2010)

Statute of the International Criminal Tribunal for the Prosecution of Persons Responsible for Genocide and Other Serious Violations of International Humanitarian Law Committed in the Territory of Rwanda and Rwandan citizens Responsible for Genocide and other such Violations Committed in the Territory of Neighbouring States between 1 January and 31 December 1994 see United Nations (UN) : International Law Documentation www.un.org (accessed 30 June 2010)

The battle of evermore? Global lessons from hard versus soft laws for monitoring forestry www.fao.org/docrep (accessed 21 March 2009)

The USDA set to become the New Face of Burma's Dictatorship www.burmacampaign.org.uk/index.php/burma/news (assesssed 31 May 2009)

The World Factbook :www.cia.gov (accessed 24 October 2008)

Tomas Ojea Quintana / Top News www.topnews.in/people/tom-s-ojea-quintana (accessed 28 May 2009)

The Concept Of International Legal Personality: An inquiry into the History and Theory of International Law http://goliath.ecnext.com (accessed 14 April 2010)

TNC's at work in Burma http://www.thirdworldtraveller.com/transnational_corps/FuelOppress_Burma.html ( accessed 26 February 2009)

The TNC's and Arms Production www.geocities.com/virtualtruth/tnc.htm (accessed 19 May 2009)

Tripartite Declaration Of Principles concerning Multinational Enterprises And Social policy,ILO 1977, www.ilo.org/public (accessed 16 February 2009)

The Nuremberg Trial $60^{\text {th }}$ Anniversary http://www.adl.org/education/dimensions_19/section3/krupp.asp (accessed 20 March 2009)

The pipeline To Riches http://www.bangkokpost.com (last accessed 11 April 2010)

Transnational Organized Crime www.g7.utoronto.ca (accessed 11 April 2010)

Total Oil : Fuelling the oppression in Burma www.birmaniademocratica.org (accessed 12 July 2010) 
UN rights envoy says Burma's judiciary system flawed

http://www.mizzima.com/news/world (accessed 31 May 2009)

U.S.Department Of State on Burma www.state.gov/r/pa (accessed 10 July 2010)

United Nations Conference On Trade And Development www.unctad.org (accessed 29 April 2009)

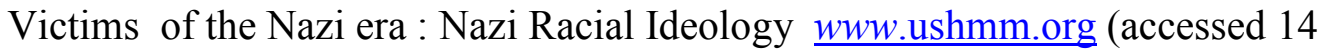
July 2010)

UNCTAD.ORG Press Expansion Of Fdi Flows Through 2009 www.unctad.org/ (accessed 20 March 2009)

World: Freedom House Ranks Most Repressive Countries www.rferl.org (accessed 1 November 2008)

World News/ Who's buying Burma's gems? (World)/Newser

www.newser.com/archive-world-news ( assesssed 26 february 2009)

World Ruled By Transnational Corporations. www.columban.com/stateofplanet 1.htm

( accessed 17 March 2009)

Wiwa v Shell The Case Against Shell wiwavshell.org/the-case-against -shell (accessed 14 May 2009)

World Investment Report 2009 www.unctad.org/wir (accessed 12 April 2010)

1945-1953-Krupp After The war www.globalsecurity.org/military (last accessed 10 July 2010)

\section{Yearbooks}

Human Rights Documentation Unit "Violations Against The Dignity,Livelihoods and Fundamental Rights of the People of Burma" (2007) Burma Yearbook On Human Rights, 27

Principles of International Law Recognized In the Charter of the Nurnberg Tribunal and in the Judgment of the Tribunal (1950) Yearbook Of The

International Law Commission

United Nations "Towards development, Security and Human Rights for All" (2005) Yearbook of the United Nations

\section{E Manuals}

EarthRights International, Transnational Litigation Manual For Human Rights and Environmental Cases in United States Courts (A resource for non lawyers, 2006) 


\section{F Thesis}

De Schutter,Oliver " Transnational Corporations And Human Rights: An Introduction" (Global Law Working Paper 01/05, New York University, New York,2005)

Tofalo,Ines “Overt and Hidden Accomplices:Transnational Corporations' Range of Complicity for Human Rights Violations" (Global Law Working Paper 01/05, New York University School Of Law, New York, 2005)

\section{G Issue Papers}

Ashley South "Burma The Changing Nature Of Displacement Crises" RSC Working Paper No.39 (Paper prepared in conjunction with the RSC workshop 'Conflict Violence and Displacement in Burma' (2006)

Advisory Council Of Jurists Reference "Human Rights And Corporate Accountability” (APF Conference Paper, 2008)

EarthRights International "The International Law Standard For Corporate Aiding And Abettting Liability" Paper Presented to the U.N.Special Representative to the Secretary

General on Human Rights and Transnational Corporations and other Business Enterprises (2006)

Jan Wouters , Leen De Smet, Cedric Ryngaert "Tort Claims Against Multinational Companies for Foreign Human Rights Violations Committed Abroad:Lessons from the Alien Tort Claims Act?" Working Paper No.46 (2003)

Paper For The International Society For the Reform Of Criminal Law , $13^{\text {th }}$ International Conference, Commercial And Financial Fraud, A Comparative Perspective, Malta 19993,4

Tyler R.Giannini Destructive Engagement : A Decade Of Foreign Investment In Burma in an Issue Paper of EarthRights International's Burma Project, (1999)

Advisory Council Of Jurists Reference "Human Rights And Corporate Accountability” (APF Conference Paper, 2008)

John Gerard Ruggie "Business And Human Rights The Evolving International Agenda" (A working paper of the Corporate Social Responsibility Initiative, 2007)

Olivier De Schutter "Extraterritorial Jurisdiction As a Tool for improving the Human Rights Accountability of Transnational Corporations" (background paper to the seminar organized in collaboration with the office of the UN High Commissioner For Human Rights) 
Natalya S. Pak, James P. Nussbaumer "Beyond Impunity : Strengthening the Legal Accountability of Transnational Corporations for Human Rights Abuses" Working papers no.45, (2009)

\section{H Memorandums}

Mcgregor, Michael "Regarding State Owned Resources, or in the alternative, resources in which the state has the primary or superior interest-would exploitation of such resources constitute pillage as that term is defined in international criminal Law? And Would such a Conduct be a crime against humanity as it is a state owned resource, or a resource in which the state has the primary or superior interest?", (Memorandum For The Office Of The Prosecutor Special Court Of Sierra Leone) (2008)

\section{TABLE OF CASES}

\section{Cases From Other Jurisdictions}

\section{A United States Of America}

Doe v Unacol (2002) 395 F.3d $932\left(9^{\text {th }}\right.$ Cir $)$

In the matter of Oil Spill by the Amoco Cadiz off the coast 954 F.2d 1279 (Seventh Circuit 1992

Khulumani v Barcaly National Bank Ltd, (2007)504 F.3d 254 (2d cir)

Lungisile Ntsebeza v Daimler and Khulumani v Barclays National Bank Ltd, 1;02-md01499-SAS 135 (DNY Cir)

Wiwa v Royal Dutch Petroluem (2000) 226 F 3d 88 (2d Cir)

\section{B International Ad Hoc Tribunals}

Prosecutor v Blaskic (IT-95-14-T)(Trial Chamber)(Judgment)( 3 March 2000)

Prosecutor v Furundzija (IT-95-17-T) (Trial Chamber) (Judgment)(10

December 1998)

Prosecutorv Zejnil Delali, Zdravko Muci, Hazim Deli, Esad Land (Judgment) (16 November 1998) (IT-96-21) (Trial Chamber, ICTY) 
Prosecutor v Tadic (IT-94-1-A) (Judgment) (15 July 1999) (Appeals

Chamber, ICTY)

Prosecutor v Kunarac (Judgment) (22 February 2001) (IT-96-23-A)

(Appeals Chamber, ICTY)

Prosecutor v Akayesu (Judgment) (2 September 1998) (ICTR-96-4-T)(Trial

Chamber,ICTY)

Prosecutor v Kupreskic (IT-95-16-A) (Appeal Chamber) (Judgment) (23

October 2001)

Prosecutor v Dr Milomir v Stakic (IT-97-24-T) (Judgment) (Trial Chamber

II) (31 July 2003)

\section{Nuremberg}

United States Of America v Carl Krauch,Herman Schmitz,Georg Von Schnitzler,Fritz Gajewski,Heinrich Hoerlein,August Von Knieriem,Fritz Ter Meer, Christian Schneider, Otto Ambros, Max Brueggemann,Ernst Buergin,Heinrich Buete-Fisch,Paul Haefliger,Max Ilgner,Friedrich Jaehne, Hans Kuehne, Carl Lautenschlaeger,Wilhelm Mann, Heinrich Oster, Karl Wurster,Walter Duerrfeld,Heinrich Gattineau,Erich von Der Heyde,Hans Kugler, officials of Farbenindustrie Aktiengesellschaft (1952) VII , Trials Of War Criminals Before The Nuremberg Military Tribunals,

United States Of America v Alfried Krupp Von Bohlen Und Halbach, Ewald Oskar Ludwig Loeser,Eduard Houdremont,Erich Mueller,Friedrich Wilhelm Janssen,Karl Heinrich Pfirsch, Max Otto Ihn,Karl Adolf Ferdinand,Heinrich Leo Korschan, Friedrich von Buelow, Werner Wilhel Heinrich,Hans Albert Gustav, (1952) IX, Trials Of War Criminals Before The Nuremberg Military Tribunals

United States Of America v Friedrich Flick,Otto Steinbrinck,,Odilo Burkart,Konrad Kaletsch,Bernhard Weiss, Hermann Terberger (1952) VI Trials Of War Criminals Before The Nuremberg Military Tribunals

Hechingen Deportation

United States Of America v Oswald Pohl And Seventeen Others, (1949) V, Trials Of War Criminal Before The Nuremberg Military Tribunal

United States Of America v Ernst von Weizaecker And Twenty Others (1949) XIV Trials Of War Criminals

The Synagogue Case 
United Nations War Crimes Commission, Law Reports Of Trials Of War Criminals Zyklon B Case

\section{International Court Of Justice (ICJ)}

Democratic Republic Of The Congo (DRC) v Uganda (Judgment) (19

December 2005) (ICJ)

Reparation For Injuries Suffered In The Service Of The United Nations (Advisory Opinion) (1949) ICJ

The Case Of S.S. Lotus (France v Turkey) (Judgment) 1927 PCIJ

The Barcelona Traction Light And Power Company Limited (Judgment)(1970) IC

\section{E Special Court Of Sierra Leone}

Prosecutor v Alex Tamba Brima, Brima Bazzy Kamara,Santigie Borbor Kanu (Special Court For Sierra Leone)(Judgment) (20 June 2007) (SCSL-04-16-T) (Trial Chamber II) 